UNIVERSIDADE DE SÃO PAULO

INSTITUTO DE GEOCIENCIAS

\title{
O CONTATO ENTRE O GRUPO PASSA DOIS E A FORMAÇÃO PIRAMBÓIA NA BORDA LESTE DA BACIA DO PARANÁ NO ESTADO DE SÃO PAULO
}

Sérgio Luís Fabris de Matos

Orientador: Prof. Dr. Armando Márcio Coimbra

DISSERTAÇÃO DE MESTRADO

COMISSÃO JULGADORA

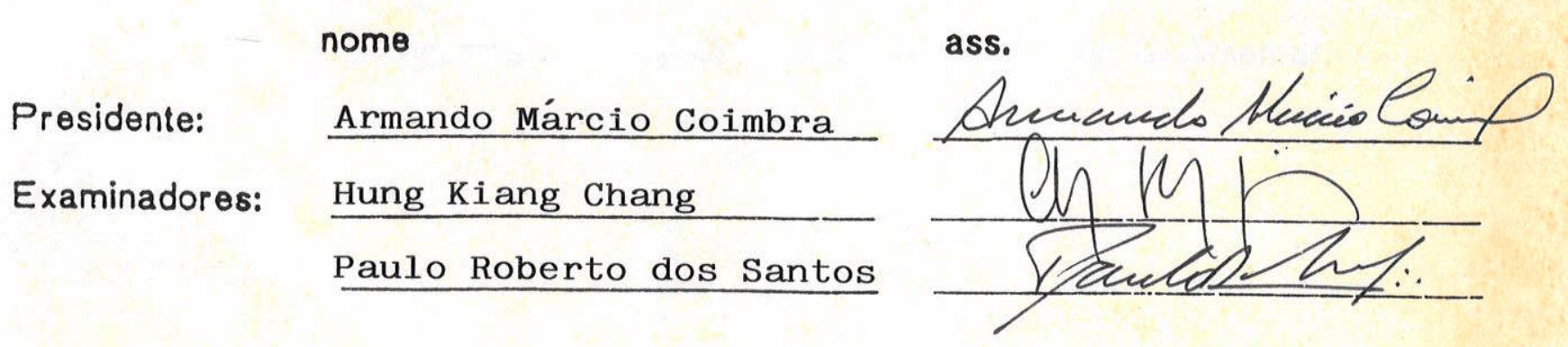


UNIVERSIDADE DE SÃO PAULO

INSTITUTO DE GEOCIENCIAS

\section{O CONTATO ENTRE O GRUPO PASSA DOIS E A FORMAÇÃO PIRAMBÓIA NA BORDA LESTE DA BACIA DO PARANÁ NO ESTADO DE SÃO PAULO}

Sérgio Luís Fabris de Matos

Orientador: Prof. Dr. Armando Márcio Coimbra

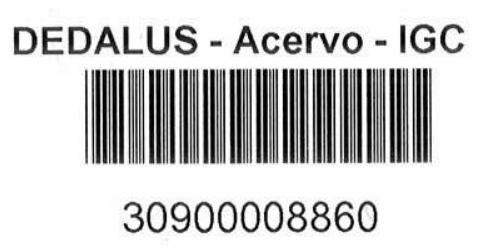

DISSERTAÇÃO DE MESTRADO

Programa de Pós-Graduação em Geologia Sedimentar

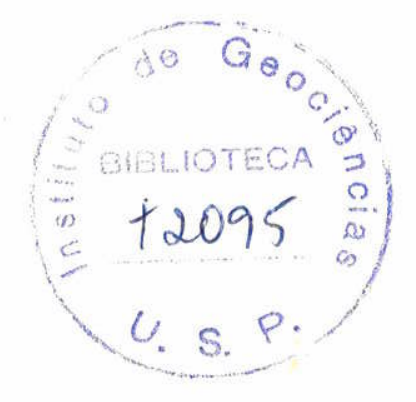

São Paulo

1995 


\section{RESUMO}

O objetivo deste trabalho foi determinar as relações de contato entre o Grupo Passa Dois e a Formação Pirambóia no Estado de São Paulo. Este contato foi por muito tempo referido como uma desconformidade, caracterizando um grande hiato no registro sedimentar da Bacia do Paraná. O "regolito fóssil", considerado o marco principal deste contato, seria um intervalo de brechas na base da Formação Pirambóia.

Através do estudo de fácies foi reconhecida a atuação de processos deposicionais regidos por marés no "regolito fóssil", intercalando produtos da deposição de sedimentos finos e de exposição e constituindo, da base para o topo, uma sucessão de fácies com passagem transicional entre depósitos de porções cada vez mais altas de planícies de maré.

Algumas características deste intervalo, como a constância litológica ao longo da faixa de afloramentos, o contato transicional com as unidades do topo do Grupo Passa Dois (formações Corumbataí, Teresina e Rio do Rasto) e o posicionamento estratigráfico característico, permitiram o estabelecimento de nova unidade litoestratigráfica denominada Camada Porangaba, substituindo a denominação "regolito fossil" e passando a integrar o topo do Grupo Passa Dois.

Sobre esta camada ou sobre a Formação Corumbataí, sempre em contato abrupto, estão os arenitos da Formação Pirambóia, considerados de origem eólica, com fácies de duna e interduna. O comportamento das paleocorrentes foi estudado nesta unidade, propondo-se novos procedimentos para o tratamento de dados. Obteve-se um sentido geral NW $\leftrightharpoons S E$ para os paleoventos que atuaram na deposição da base da unidade.

A inexistência de hiatos expressivos, de feições de erosão ou de exposição prolongada foi demonstrada pelas relações de contato entre as unidades presentes, pela persistência das feições paleogeográficas e condições climáticas áridas e ainda pela gênese dos depósitos, a qual mostrou a continuidade da deposição em planícies de maré na Camada Porangaba.

$\mathrm{Na}$ Formação Teresina foram ainda reconhecidas evidências de atividade hidrotermal em superfície, representada por corpos silicosos do tipo geiseritos na região de Anhembi. 


\section{ABSTRACT}

The aim of the present study was the knowledge of the contact relations between the Passa Dois group and the Pirambóia formation. This contact has been considered a disconformity, expressing a large hiatus in the sedimentary record of the Parana basin. The "fossil regolith ", the mark of this contact, is a breccia bed in the Pirambóia formation base.

A facies study allowed the recognition of tidal-controlled deposition the "fossil regolith," intercalating fine sediment and exposition products and constituting, upward, a facies succession that records the transitional passage of progressively higher locations of tidal flats.

The lithologic constancy in the outcrop strip, the transitional contact with the top of Corumbataí, Teresina and Rio do Rasto formations (Passa Dois group) and the stratigraphic position are some characteristics that permitted the creation of a new stratigraphic unit called Porangaba bed, in substitution to "fossil regolith" and considered as parts of the top of Passa Dois group.

On top of Porangaba bed or Corumbataí formation, always in sharp contact, there are the Pirambóia formation sandstones that have an aeolian control, composed by dune and interdune facies. The behavior of the paleocurrents was studied in this unit, with proposition of new procedures for the data treatment. The result was a NW $\leftrightharpoons$ SE general trend for the paleowinds responsible by the deposition of this unit.

The demonstration of the nonexistence of large hiatus, erosion marks or large time expositions has been achieved through the contact relations between the present units, the continuity of paleogeographic configuration and the genesis of the rocks, which prove the continuity of sedimentation in tidal flats yet in the Porangaba bed.

In Teresina formation hidrothermal activity in surface has been recognized by the presence of siliceous bodies resembling geyserits in Anhembi region. 


\section{AGRADECIMENTOS}

Durante a execução deste trabalho a colaboração de várias pessoas foi extremamente importante.

A autor gostaria de agradecer:

- ao professor e amigo Armando Márcio Coimbra, pela orientação dedicada e decisiva para a execussão deste trabalho;

- aos meus pais, Acir Sérgio de Matos e Gracieta Fabris de Matos, pelo constante incentivo e suporte financeiro;

- ao meu irmão Paulo Sérgio Fabris de Matos, pela ajuda com aplicativos e compiladores nem sempre amigáveis;

- ao professor e amigo Cláudio Riccomini, pelas pertinentes sugestões dadas durante a execução do trabalho; preliminar;

- ao amigo Jorge Hachiro palas freqüentes discussões e leitura crítica do texto

- aos amigos Ana Maria Góes, Carlos Augusto Frazão Pereira, Luiz Alberto Fernandes e Mário Sérgio de Melo, que com suas sugetões contribuiram para o desenvolvimento deste trabalho;

- ao professor Max Brandt Neto pela obtenção das imagens de argilominerais por microscopia eletrônica de varredura;

- ao professor Daniel Atencio e o físico Flávio M. S. Carvalho pela obtenção de difratogramas de raios $\mathrm{X}$;

- à FAPESP (processo Geologia 89/3247-6) pelo suporte financeiro;

- à Petrobrás-Nexpar pela possibilidade de consulta e fornecimento de material de seu acervo bibliográfico;

- especialmente à Sandra Akemi Iwata pela ajuda, companhia, apoio e incentivo constantes durante todo o trabalho. 


\section{ÍNDICE}

RESUMO

AGRADECIMENTOS

Indice de figuras

Índice de tabelas

1. INTRODUÇÃO

2. MÉTODOS E TÉCNICAS

2.1. Análise de fácies

2.2. Obtenção de dados

2.2.1. Pesquisa bibliográfica

2.2.2. Trabalhos de campo

2.2.3. Dados de subsuperfície

2.3. Tratamento de dados

2.3.1. Análise sedimentológica

2.3.2. Análise de paleocorrentes

2.3.3. Determinação de argilominerais

2.3.3.1. Difratometria de raios $X$

2.3.3.2. Microscopia eletrônica de varredura

3. ESTÁGIO ATUAL DE CONHECIMENTO SOBRE O CONTATO PASSA DOIS -

3.1. As unidades do Grupo Passa Dois

3.2. A Formação Pirambóia

3.3. Idade dos depósitos

4.1. Formação Corumbataí

4.1.1. Litotipos

4.1.2. Fósseis

4.2. Formação Teresina

4.2.1. Litotipos

4.2.2. Fósseis

4.3. Formação Rio do Rasto, Membro Serrinha

4.3.1. Litotipos

4.3.2. Fósseis

4.4. Brechas presentes no contato Passa Dois-Pirambóia

4.4.1. Conhecimento atual

4.4.2. Litotipos

4.4.3. Fósseis

4.5. Formação Pirambóia

4.5.1. Litotipos

4.5.2. Paleocorrentes

4.5.2.1. Trabalhos anteriores

4.5.2.2. Resultados obtidos

\section{DESCRIÇÃO DAS LITOFÁCIES}


5.5. Litofácies S

5.6. Litofácies BI

5.7. Litofácies Ba

5.8. Litofácies $\mathrm{Ai}$

5.9. Litofácies Am

5.10. Litofácies Ac

5.11. Litofácies Ap

6. RELAÇÕES ENTRE AS LITOFÁCIES - SUCESSÃO

6.1. Intervalo correspondente ao topo das unidades Teresina, Corumbataí e Rio do Rasto

6.2. Brechas do contato

6.3. Intervalo correspondente à base da Formação Pirambóia

7. INTERPRETAÇÖES GENÉTICAS

7.1. Ambiente de planícies de maré em mar epicontinental rasc

7.2. Mares de areia

7.3. Interpretação paleoclimática

7.4. Contexto paleotectônico

7.5. Hidrotermalismo

7.5.1. Origem e funcionamento dos gêiseres

7.5.2. Idade e gênese dos geiseritos de Anhembi

8. ESTABELECIMENTO DE NOVA UNIDADE LITOESTRATIGRÁFICA: CAMADA PORANGABA

9. O CONTATO PASSA DOIS-PIRAMBÓIA E AS SEQÜÉNCIAS ESTRATIGRÁFICAS

9.1. Trabalhos anteriores

9.2. O significado do contato

10. CONSIDERAÇÕES FINAIS

13. ANEXO - Pontos analisados - localização e unidades presentes 
Indice de figuras

Figura 1: Mapa de localização dos afloramentos estudados e dos perfis (geologia

Figura 2: $\quad$ Áreas definidas pelos valores da média de dados por intervelo mais e menos um desvio padrão em distribuição normal. A área mais escura indica os valores anomalamente mais altos e a área mais clara os valores anomalamente mais baixos.

Figura 3: A.Diagrama circular com dados de paleocorrentes plotados (๑) em distribuição contínua.

B e C. Resáceas com distribuição dos em intervalos de $10^{\circ}$ e rotação de $5^{\circ}$.

Figura 4: Rosáceas com distribuição dos dados de paleocorrentes em intervalos de $30^{\circ}$ e rotações de $5^{\circ}$.

Figura 5: Fluxograma geral do programa AZIMED1, utilizado no tratamento dos dados de paleocorrente

Divisão litoestratigráfica adotada para a Bacia do Paraná (modificada de Almeida \& Melo 1981, Lavina 1991, Hachiro et al. 1993 e Milani et al. 1994).

Figura 7: Gravura representando corpos geminados, compartilhando a mesma base, $10 \mathrm{~km}$ a oeste de Anhembi, próximo ao vale do Ribeirão do Retiro.

Figura 6:

Figura 8

Distribuição das medidas do rumo de mergulho de estratos cruzados da base da Formação Pirambóia (só foram utilizados estratos com mergulho igual ou superior a $5^{\circ}$ ). Para cada ponto estão apresentados: a. diagrama de distribuição contínua com o número de dados, resultado do azimute do vetor médio, razão de consistência do vetor médio e desvio padrão angular ; e b. rosácea com distribuição dos dados em intervalos de $30^{\circ}$, na configuração que apresenta o vetor médio mais próximo do obtido na distribuição contínua e polaridade.

Figura 9: $\quad$ Diagrama da distribuição dos vetores obtidos, proporcionais às suas razões de consistência, apresentando o vetor médio geral.

Figura 10

Modelo da sucessão $A$, baseada nos dados de floramentos e de subsuperficie.

Figura 11: Legenda para as seções das brechas do contato alinhadas segundo perfis: A-A'; B-B'; C-C'; D-D'; E-E'; F-F'; G-G' .

Figura 12: A - Distribuição dos argilominerais das unidades Corumbataí, Teresina e Rio do Rasto (segundo Rodrigues \& Quadros 1976);

B - Curvas de isoteores de boro das unidades Corumbataí, Teresina e Rio do Rasto (segundo Rodrigues \& Quadros 1976);

C - Sobreposição da distribuição dos argilominerais e curvas de isoteores de boro das formações Corumbataí, Teresina e Rio do Rasto (Membro Serrinha).

Figura 13: A - Mapa de isópacas das formações Teresina, Corumbataí e Rio do Rasto - Membro Serrinha (segundo Northfleet et al. 1969);

B - Mapa de isópacas da Formação Pirambóia (segundo Soares 1973). 
Figura 14: Modelo genérico de um sistema hidrotermal em profundidade, abastecido por águas de origem meteórica, resultando, após aquecimento e transporte para a superfície, em gêiseres e fontes termais (segundo White 1967 e Gupta 1980).

Figura 15: Seqüências estratigráficas reconhecidas na Bacia do Paraná. 
Indice de tabelas

Tabela 1: Padrões de distribuição de intervalos modais segundo 0 critério de polaridade.

Tabela 2: $\quad$ Argilominerais identificados por difratometria de raios $X$ e/ou por microscopia eletrônica de varredura (MEV).

Tabela 3: $\quad$ Resultados das análises de paleocorrente da base da Formação Pirambóia.

Tabela 4: Descrição das fácies reconhecidas e suas relações com as unidades litoestratigráficas.

Tabela 5: Quadro relacionando: fácies, unidades litoestratigráficas, produtos, processos geradores, interpretação paleoambiental e ambientes sedimentares principais. 


\section{INTRODUÇÃO}

O contato Passa Dois - Pirambóia foi considerado como uma das mais importantes e notáveis desconformidades do registro geológico da Bacia do Paraná (e.g. Gordon Jr. 1947, Sanford \& Lange 1960, Gama Jr. et al. 1982, Zalán et al. 1990), demarcando hiato erosivo e/ou deposicional expressivo. Entretanto, Vieira (1973) e Riccomini et al. (1984), no Estado do Paraná, descreveram passagem transicional entre depósitos do Grupo Passa Dois (Formação Rio do Rasto) e da Formação Pirambóia. Lavina (1991) reconheceu, no Estado do Rio Grande do Sul, passagem transicional entre os depósitos do Grupo Passa Dois e a Formação Sanga do Cabral do Grupo Rosário do Sul, considerada correlata à Formação Pirambóia.

No Estado de São Paulo, o contato entre rochas do topo do Grupo Passa Dois (unidades Corumbataí, Teresina e Rio do Rasto) e da base da unidade Pirambóia foi sempre caracterizado como uma discordância, cujo marco seria a camada denominada genericamente por "solo fóssil" (e.g. Washburne 1930, Almeida \& Barbosa 1953), "regolito fóssil" (e.g. Almeida 1954, Soares 1973) ou simplesmente "brecha" (e.g. Fúlfaro 1970), interpretada como originada por pedogennese e/ou por processos físicos, trativo ou de fluxo gravitacional.

Procurou-se demonstrar que o contato Passa Dois - Pirambóia caracteriza-se pela inexistência de hiato deposicional expressivo e/ou de hiato erosivo como referido em textos (e.g. Soares 1973, Zalán et al. 1990), mas por variações ambientais que não implicaram em retrabalhamento ou erosão do topo de unidades sotopostas.

Nesta demonstração foi aplicada a análise de fácies, com posterior síntese dos possiveis paleoambientes e a paleogeografia. Para tanto foram necessárias: a catalogação dos dados existentes, a busca de novos detalhes em afloramentos e a ứilização de métodos de tratamento de dados que permitissem bom entendimento do binômio processo-produto de cada fácies.

A pesquisa foi realizada principalmente em afloramentos nos quais estivesse exposto o contato entre os topos das unidades Teresina, Corumbataí ou Rio do Rasto e base da Formação Pirambóia. Os afloramentos foram buscados, em sua maior parte, na atual borda leste da Bacia do Paraná no Estado de São Paulo (porção ocidental da Depressão Periférica), em duas faixas, uma de direção NE-SW, entre as localidades de Santa Rosa de Viterbo e Itapetininga, onde ocorrem exposições dos contatos Corumbataí - Pirambóia e Teresina - Pirambóia; e outra de direção E-W, de Itapetininga a Fartura, onde ocorrem os contatos Teresina - Pirambóia e Rio do Rasto - Pirambóia (Figura 1). Nestas duas faixas estão presentes, de maneira descontínua, os afloramentos dos contatos. 


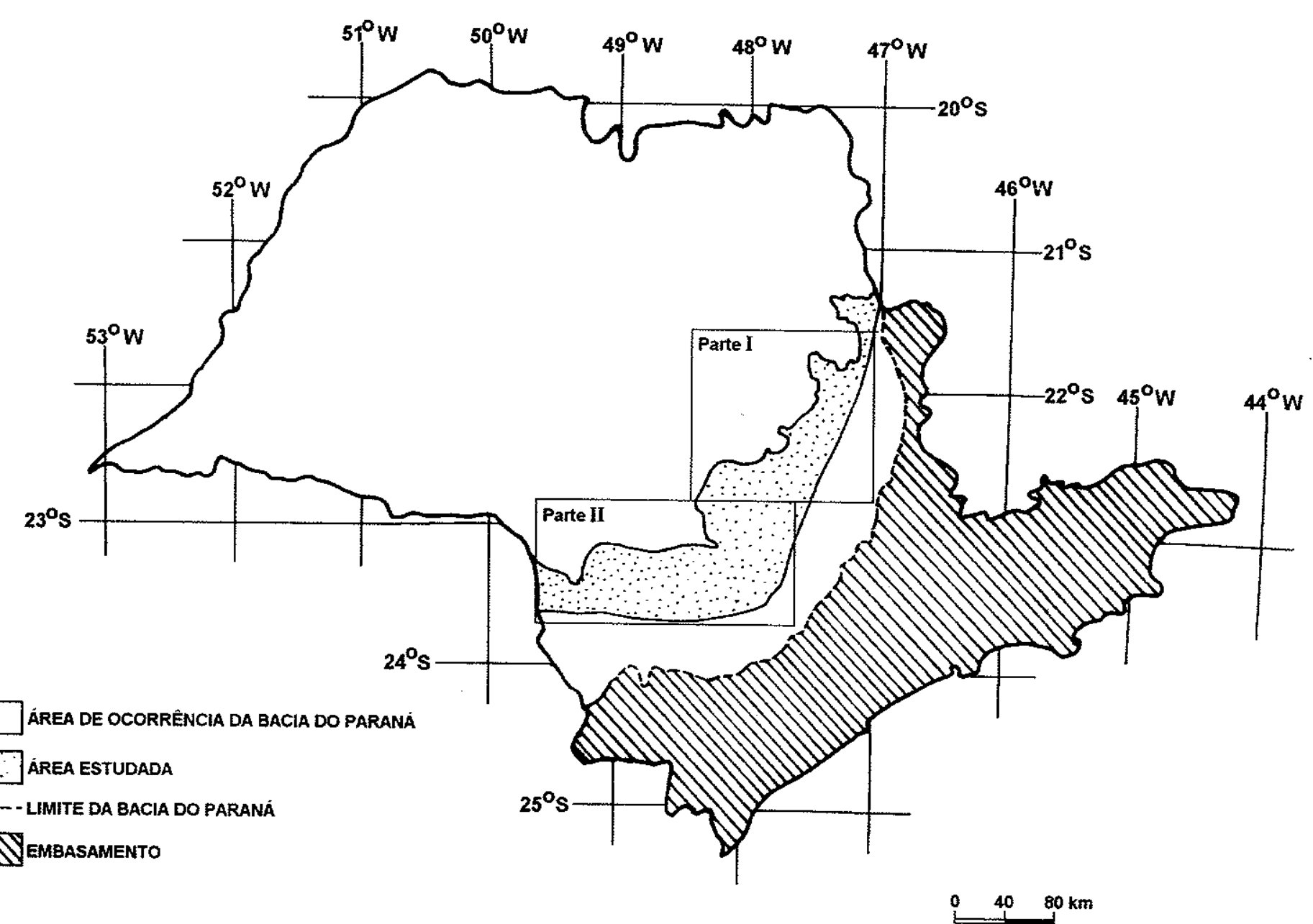

\begin{tabular}{|c|c|}
\hline \multicolumn{2}{|r|}{ ESTRATIGRAFIA } \\
\hline \multicolumn{2}{|r|}{ COBERTURAS CENOZÓICAS } \\
\hline QA & SEDIMENTOS ALUVIONARES \\
\hline TQA & FORMAÇÁOO RIO CLARO \\
\hline TQIA & COBERTURAS INDIFERENCIADAS \\
\hline \multicolumn{2}{|r|}{ BACIA DO PARANÁ } \\
\hline \multicolumn{2}{|r|}{ GRUPO SÄO BENTO } \\
\hline JKSC & FORMAÇĀO SERRA GERAL \\
\hline JKW & INTRUSIVAS BÁSICAS \\
\hline $\mathrm{JKB}$ & FORMAÇÃO BUTUCATU \\
\hline TRJP & FORMAÇÃO PIRAMBÓIA \\
\hline \multicolumn{2}{|r|}{ GRUPO PASSA DOIS } \\
\hline PRR & FORMACÁA RIO DO RASTO \\
\hline PT & FORMAÇÁ TERESINA \\
\hline PSA & FORMAÇÄO SERRA ALTA \\
\hline$P C$ & FORMAÇÁO CORUMBATAII \\
\hline $\mathrm{PI}$ & FORMAÇĀO IRATI \\
\hline \multicolumn{2}{|r|}{ GRUPO TUBARÄO } \\
\hline PP & FORMAÇÃO PALERMO \\
\hline PRB & FORMAÇÁO RIO BONITO \\
\hline PTT & FORMAÇAOO TATUÍ \\
\hline $\mathrm{CPI}$ & FORMAÇÁ ITARARE \\
\hline CPA & FORMAÇĀO AQUIDAUANA \\
\hline
\end{tabular}

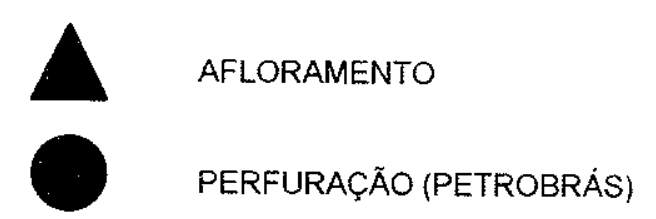

$X+-1 X$ PERFIL

FIGURA 1: Mapa de localização dos afloramentos estudados e perfis (geologia baseada em Bistrichi et al. 1981). 


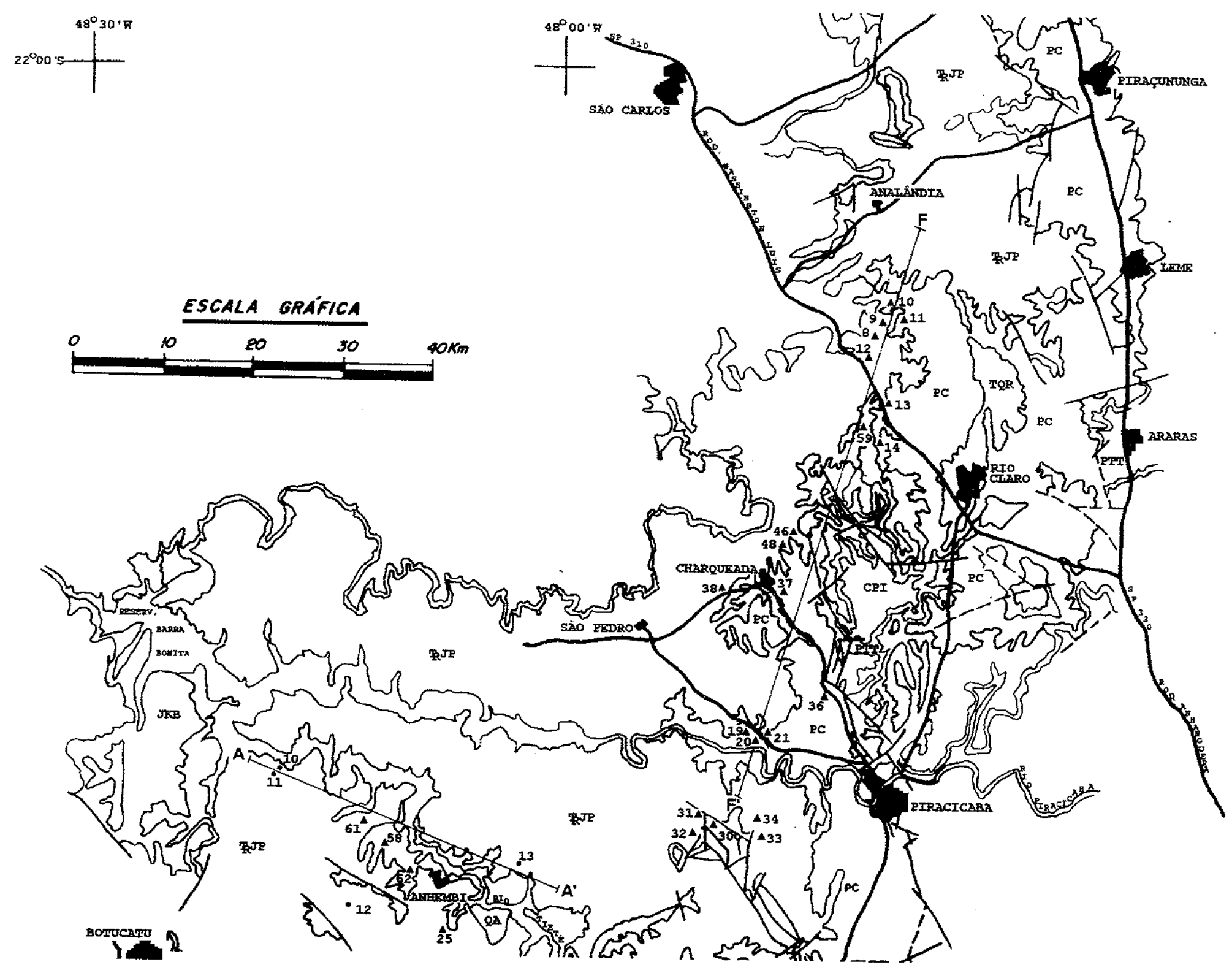

Figura 1: Mapa de localização - Parte I 

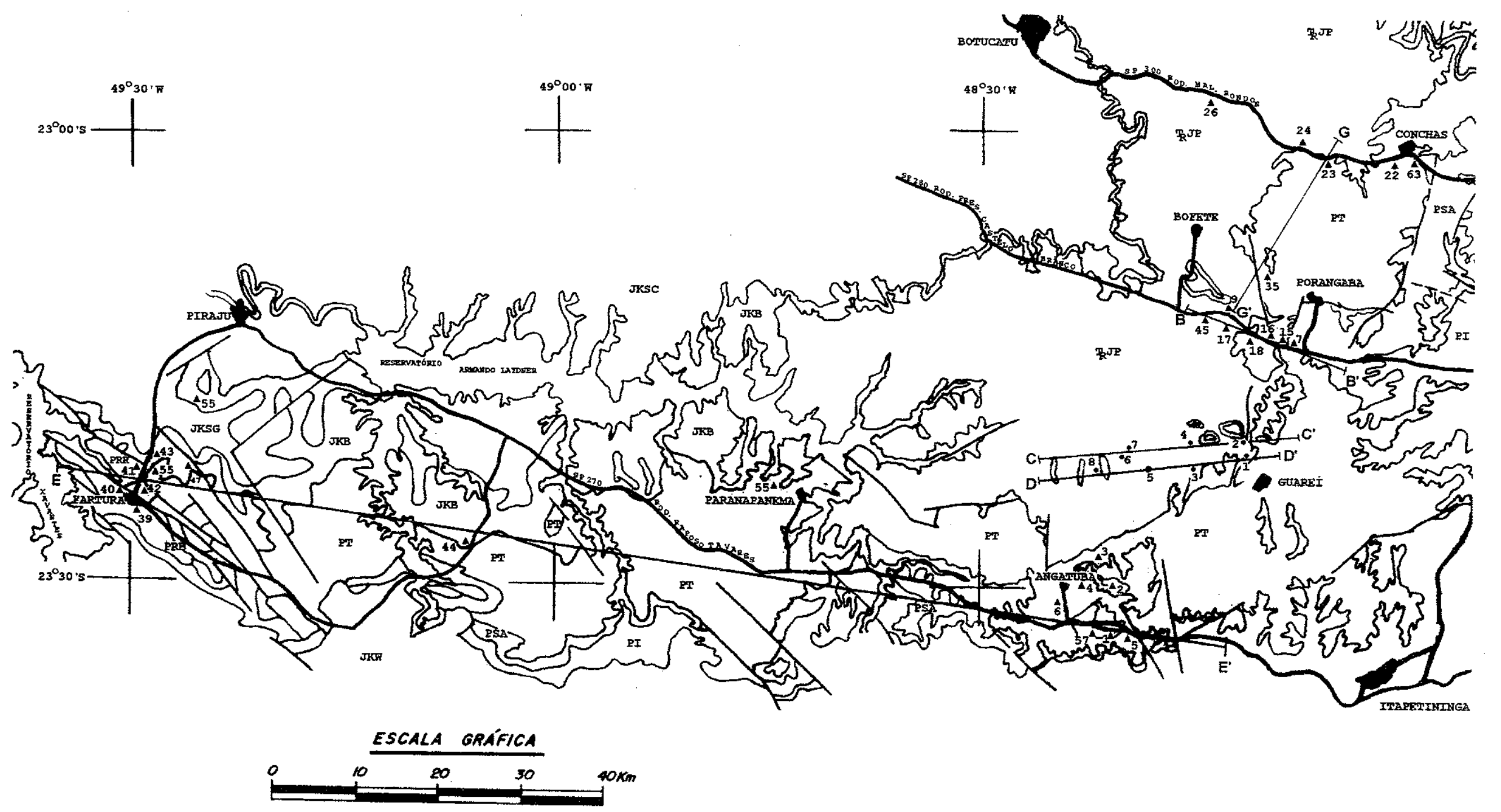


\section{MÉTODOS E TÉCNICAS}

\subsection{Análise de fácies}

A análise de fácies constituiu o escopo principal do presente trabalho. Foram escolhidos métodos e técnicas, tanto na obtenção quanto no tratamento de dados, os quais permitiram a identificação e interpretação das fácies.

Fácies sedimentar é o conjunto de atributos de uma rocha ou unidade sedimentar que a distingue de outras unidades associadas ou adjacentes. Sendo assim, a fácies pode ser definida com base nos aspectos: a) litológico, que envolve características mineralógicas e texturais; b) estruturas sedimentares, com destaque para as que permitem definição de paleocorrentes (úteis também na interpretação paleogeográfica); c) conteúdo fossilífero; d) aspectos geométricos, ou seja, forma dos corpos ou pacotes rochosos.

Sucessão de fácies constituí-se de uma série de fácies, as quais passam de uma para outra, com progressivas mudanças em suas características.

Ambiente sedimentar é a parte da superfície terrestre caracterizada por propriedades físicas, químicas e biológicas, sujeitas a controles como: fauna, flora, clima, profundidade, salinidade, correntes e tectônica (Selley 1985).

A análise de fácies e posterior definição de sucessões e ambientes deposicionais foi executada nas seguintes etapas:

(1) Descricão - Identificação, definição e descrição de fácies;

(2) Interpretação - análise dos processos sedimentares geradores (físicos, químicos e biológicos) das fácies e definição de sucessões;

(3) Síntese - combinação dos processos geradores e da evolução da deposição, com interpretações paleoambiental e paleogeográfica.

O estudo de fácies tem como princípio a "Lei de Correlação de Fácies de Walther", a qual foi resgatada e adaptada por autores como Visher (1965) e Middleton (1973), podendo ser assim sintetizada: Somente estarão superimpostas aquelas fácies que puderem ser observadas lado a lado no presente. Fraser (1989) alerta que o inverso da lei não é necessariamente verdadeira, pois uma seqüência vertical pode não reproduzir uma distribuição lateral de fácies. Walker (1992) ressalta que se o contato entre duas fácies for gradacional, então representa ambientes que estiveram pelo menos uma vez lado a lado, mas, se houver contatos abruptos (sharp) ou erosivos, não há como identificar se os ambientes foram adjacentes ou não. 


\subsection{Obtenção de dados}

\subsubsection{Pesquisa bibliográfica}

Constituiu-se principalmente da compilação de dados existentes sobre o tema, onde foram procurados o estágio atual do conhecimento do contato Passa DoisPirambóia, e de uma revisão sobre as unidades que o compõem.

$O$ item 3 deste trabalho concentra dados básicos sobre estas unidades e a divisão adotada.

Também foram revistos temas como: técnicas e métodos analíticos em sedimentologia e conceitos de fácies e sistemas deposicionais.

\subsubsection{Trabalhos de campo}

Os trabalhos de campo se concentraram na procura de informações para o desenvolvimento do tema, com detalhamento de afloramentos conhecidos e busca de novas exposições do contato estudado

Foram executados segundo métodos convencionais, ao longo da faixa de afloramentos da borda leste da Bacia do Paraná no Estado de São Paulo (Figura 1), valendo-se da malha viária bastante densa neste Estado. São numerosas tanto as vias pavimentadas, onde foram encontrados os melhores afloramentos, como as não pavimentadas, importantes no rastreamento do intervalo em estudo. Nos afloramentos foram descritas seções, coletadas amostras para análise e dados para estudos de paleocorrentes.

Para orientação no campo foram utilizadas folhas topográficas, nas escalas 1:50.000 do IBGE e 1:10.000 do Plano Cartográfico do Estado de São Paulo, e mapas geológicos locais (e.g. Fúlfaro 1970, Landim 1970). A figura 1 e o anexo (item 13) apresentam os principais locais de estudo.

\subsubsection{Dados de subsuperfície}

Os dados de subsuperfície foram obtidos em relatórios de poços perfurados pela PETROBRÁS na Bacia do Paraná no Estado de São Paulo e constituíram importante complementação para as informações obtidas em rochas aflorantes.

De todas as campanhas de perfuração, a de maior utilidade foi a executada para pesquisa do arenito asfáltico da Formação Pirambóia no Estado de São Paulo, 
cujos resultados foram apresentados por Roncaratti (1971) e Thomaz Filho (1972). Nestes trabalhos estão descritos os testemunhos provenientes de 13 perfurações rasas, com testemunhagem contínua, locadas em áreas de ocorrência de exudações, coincidentes com os altos estruturais de Carlota Prenz, Guareí, Bofete, Porto Martins, Piapara e Anhembi. Essas perfurações atingiram e amostraram o contato entre as unidades Teresina e Pirambóia.

\subsection{Tratamento de dados}

\subsubsection{Análise sedimentológica}

O principal objetivo desta análise, seja em afloramento, amostras de mão, seções delgadas ou em microscópio eletrônico, foi a obtenção de parâmetros texturais, estruturais e composicionais que permitissem a melhor caracterização das fácies, dos processos geradores e conseqüentemente dos sistemas deposicionais envolvidos.

Para rochas siliciclásticas buscou-se os parâmetros composicionais, tipos de cimentação e relações de contatos entre grãos.

Para rochas carbonáticas, além dos parâmetros texturais, foi também interpretada a gênese dos grãos (aloquímicos), através de análises macroscópicas, microscópicas e composicionais, valendo-se também de técnicas como microscopia eletrônica e tingimentos com alizarina (Adams et al. 1984).

$\mathrm{Na}$ classificação de rochas foram utilizados os critérios de Folk (1974) e Pettijohn (1975) para sedimentos siliciclásticos e de Folk (1974) e Dunham (1962) para sedimentos carbonáticos. A nomenclatura das rochas foi baseada em Coimbra et al. (1992), que apresentaram proposta misturando denominações de origem latina e grega (como arenito pelítico), considerada mais usual e não prejudicial a compreensão. Para estruturas sedimentares foi utilizada classificação proposta por Coimbra et al. (1993), que reune várias classificações existentes (e.g. Pettijohn 1975, Tucker 1981, Allen 1987, Selley 1988 ), confrontando parâmetros direcionais, gênese e momento de formação.

\subsubsection{Análise de paleocorrentes}

O estudo de paleocorrentes teve sua origem nos trabalhos de Sorby na metade do século $X I X$, sendo seu uso formalizado no segundo quarto do século $X X$ por Brinkman (apud Miall 1992). A análise de paleocorrentes constitui importante 
ferramenta para o estudo de rochas sedimentares, sendo útil nas interpretaçōes de fácies (Tucker 1989) e da paleogeografia, permitindo a identificação das possíveis áreas-fonte, a direção das correntes em paleocanais, comportamento dos paleoventos e posições de paleolinhas de costa.

No presente estudo os resultados mais consistentes foram obtidos na base da Formação Pirambóia, a qual apresenta camadas com estratificações cruzadas de médio e grande porte. Foram medidos em campo, os rumos de mergulho de estratos cruzados da Formação Pirambóia, que estivessem até $10 \mathrm{~m}$ acima das camadas de brecha (regolito fóssil) ou da Formação Corumbataí, preferencialmente onde o contato fosse visivel. Tal procedimento buscou a obtenção de um controle estratigráfico, o qual permitisse a correlação entre os vários pontos de coleta.

A seguir é proposto um método de tratamento de dados que busca, além da obtenção da direção predominente de atuação do agente de transporte, uma forma clara e completa de apresentação gráfica dos resultados obtidos.

Para a apresentação e estudo das paleocorrentes optou-se pela representação bidimensional em distribuição circular, considerada a mais adequada para interpretação rápida e direta e de melhor apresentação visual. Foi buscada uma forma de análise modal e polar das rosáceas que não recorresse a padrões préestabelecidos (gabaritos), nem pessoais (avaliação visual).

Os resultados foram obtidos através de dois tipos de distribuição: contínua e em intervalos (descontínua).

Foi obtido o vetor médio, ou seja, a média geométrica na distribuição circular contínua, com significado de direção média de atuação dos agentes de transporte. Os valores de magnitude proporcional ao número de dados (consistência) e do desvio padrão angular, serviram como parâmetros para avaliar a representatividade do vetor.

$\mathrm{Na}$ distribuição em intervalos buscou-se resultados não muito evidentes na distribuição contínua. Na escolha da dimensão dos intervalos foi observada a clareza na apresentação, a conseqüente facilidade de interpretação e a manutenção das divisões em quadrantes sendo então escolhido o intervalo de $30^{\circ}$.

Foram obtidas seis configurações diferentes, através de rotações de $5^{\circ}$, das quais foi escolhida aquela com vetor médio mais próximo daquele calculado na distribuição contínua, considerada então a menos afetada pela distribuição em intervalos.

A distribuição em rosáceas permitiu as análises modal e polar, com as quais foi possivel reconhecer direções principais e secundárias de atuação do agente de transporte. A análise polar foi feita baseada na distribuição das freqüência, apresentando-se como alternativa para as análises baseadas em padrões préestabelecidos, que em geral são apenas "parecidos" com as obtidas.

Foram usados os seguintes procedimentos para a obtenção dos parâmetros: 
(1) Distribuição contínua

- Cálculo do azimute do vetor médio VM (média geométrica):

$$
\mathrm{VM}=\arctan \left(\frac{\sum_{x=1}^{\mathrm{n}} \operatorname{sen} a_{x}}{\sum_{x=1}^{\mathrm{n}} \cos a_{x}}\right)
$$

onde a representa a medida azimutal do vetor do mergulho medido, $n$ o número total de medidas.

O valor azimutal do vetor foi obtido após análise do sinal da soma dos senos e dos co-senos para identificação do quadrante do vetor calculado trigonometricamente.

- Cálculo da razão de consistência RC (magnitude do vetor resultante proporcional ao número de dados):

$$
\mathrm{RC}=\frac{1}{\mathrm{n}} \sqrt{\left(\sum_{x=1}^{\mathrm{n}} \cos a_{x}\right)^{2}+\left(\sum_{x=1}^{\mathrm{n}} \operatorname{sen} a_{x}\right)^{2}}
$$

- Cálculo do desvio padrão angular $(\sigma A)$

$$
\sigma \mathrm{A}=\frac{180^{\circ}}{\pi} \sqrt{2(1-\mathrm{R})}
$$

\section{(2) Distribicão em intervalos de $30^{\circ}$, rotacionáveis}

Adotou-se, como representação gráfica, por diagramas circulares em intervalos de $30^{\circ}$, onde os limites de classes foram rotacionados de $5^{\circ} \mathrm{em} 5^{\circ}$. Os critérios para a adoção deste intervalo foram: a melhor visualização e a preservação da divisão em quadrantes

- Cálculo do azimute do vetor médio VMI:

$$
\mathrm{VMI}=\arctan \left(\frac{\sum_{x=1}^{12} y \cdot \operatorname{sen} \frac{x \cdot 30^{\circ}+k \cdot 5^{\circ}}{2}}{\sum_{x=1}^{12} y \cdot \cos \frac{x \cdot 30^{\circ}+k \cdot 5^{\circ}}{2}}\right) 0 \leq k<6
$$


onde y representa a freqüência no intervalo $\times .30^{\circ}$ e $\mathbf{k}$ o fator de rotação. Os cálculos dos senos e cossenos são feitos a partir do valor médio do intervalo.

- Cálculo da razão de consistência $\mathrm{RCl}$ (magnitude do vetor resultante proporcional ao número de dados):

$$
\mathrm{RI}=\frac{1}{\mathrm{n}} \sqrt{\left(\sum_{x=1}^{12} y \cdot \operatorname{sen} \frac{x \cdot 30^{\circ}+k \cdot 5^{o}}{2}\right)^{2}+\left(\sum_{x=1}^{12} y \cdot \cos \frac{x \cdot 30^{\circ}+k \cdot 5^{\circ}}{2}\right)^{2}} \mid 0 \leq k<6
$$

- Cálculo do desvio padrão angular $(\sigma \mathrm{Al})$

$$
\sigma: I I=\frac{180^{\circ}}{\pi} \sqrt{2(1-R)}
$$

\section{(3) Análises modal e polar}

O estabelecimento dos intervalos modais obedeceu a seguinte condição:

$$
\mathbf{I}_{\mathrm{i}}>\overrightarrow{\mathrm{I}}+\sigma \mathrm{I}
$$

onde $\mathbf{l}_{\mathbf{i}}$ é a freqüência no intervalo $\mathbf{i}, \quad \bar{l}$ é a freqüência média por intervalo, resultado da divisão do número total de dados pelo número de intervalos e ol o desvio padrão da distribuição nos intervalos.

Os valores de $\bar{I}$ e de $\sigma$ foram assim obtidos:

$$
\begin{aligned}
& \overline{\mathrm{I}}=\frac{n}{n \mathrm{I}} \quad\{8\} \\
& \sigma \mathrm{I}=\sqrt{\frac{\sum_{i=1}^{\mathrm{n}}\left(\mathrm{I}_{i}-\overline{\mathrm{I}}\right)^{2}}{\mathrm{nI}}}
\end{aligned}
$$

onde $\boldsymbol{n}$ é o número total de dados, $\boldsymbol{n l}$ é o número de intervalos.

A condição $\{7\}$ é validada se considerada a distribuição das freqüências como uma distribuição normal onde o campo limitado pelos valores maiores que a média mais um desvio padrão contêm os valores anômalos mais altos (Figura 2 - área em preto). 


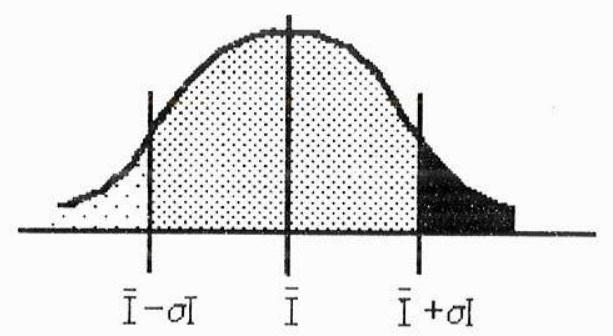

Figura 2: Áreas definidas pelos valores da média de dados por intervelo mais e menos um desvio padrão em distribuição normal. A área mais escura indica os valores anomalamente mais altos e a área mais clara os valores anomalamente mais baixos.

Este critério, porém, pode indicar a existência de mais de um intervalo que satisfaça a condição $\{7\}$ exigindo assim uma avaliação das polaridades. Para isso é proposta a seguinte classificação para os tipos de distribuição de dados de estraticações cruzadas (modificado de Potter \& Pettijohn 1977, Tucker 1981, Selley 1985 e Pettijohn et al. 1987), como apresentada na tabela 1.

\begin{tabular}{|c|c|}
\hline NÚMERO DE MODAS & POLARIDADE \\
\hline UNIMODAL & unipolar \\
\hline BIMODAL & $\begin{array}{l}\text { unipolar: menor ângulo entre os pontos } \\
\text { médios dos intervalos modais igual a } 30^{\circ} \\
\text { bipolar: } \\
\text { (1) aguda - menor ângulo entre os pontos } \\
\text { médios dos intervalos modais igual a } 60^{\circ} \\
\text { (2) ortogonal - menor ângulo entre os pontos } \\
\text { médios dos intervalos modais igual a } 90^{\circ} \\
\text { (3) aberta - menor ângulo entre os pontos } \\
\text { médios dos intervalos modais é igual a } 120^{\circ} \text { ou } 150^{\circ} \\
\text { (4) Simétrica - ângulo entre os pontos médios } \\
\text { do intervalos modais é igual a } 180^{\circ}\end{array}$ \\
\hline POLIMODAL & $\begin{array}{l}\text { unipolar: menor ângulo entre os pontos } \\
\text { médios dos intervalos modais igual a } 30^{\circ} \\
\text { randônica: qualquer outro arranjo com três } \\
\text { ou mais intervalos modais }\end{array}$ \\
\hline
\end{tabular}

Tabela 1:

Padrões de distribuição de intervalos modais segundo o critério de polaridade.

Os intervalos anomalamente altos foram considerados como a direção ou as direções principais de atuação do agente responsável pela geração da estrutura com características direcionais.

Entendido o significado geológico dos intervalos definidos como 
anomalamente altos, nota-se que a utilização simples da moda em sua definição clássica (o intervalo com a maior freqüência) pode ser incompleta e insuficiente para o caso de paleocorrentes. O método proposto procurou também substituir a interpretação "visual" ou de comparação com padrões pré-estabelecidos, estabelecendo critério único, claro e reproduzível.

Métodos computacionais mais antigos, como o de Pincus (1953 e 1956), com 36 intervalos de $10^{\circ}$, foram certamente propostos para facilitar cálculos manuais, em uma época onde o uso de cérebros eletrônicos (calculadora eletrônica ou de computador) não realizava-se em grande escala. No exemplo citado, o grande número de intervalos buscava a minimização dos efeitos da divisão por intervalos, verificada pela menor diferença entre a direção do vetor médio e a média aritmética.

Para exemplificar o procedimento ora adotado foram montados diagramas: (1) de distribuição contínua, (2) com intervalos de $10^{\circ}$ (como o de Pincus 1953) e (3) de $30^{\circ}$ (estas duas últimas com as respectivas rotaçöes), utizando-se sempre o mesmo conjunto de dados provenientes da base da Formação Pirambóia.

A figura $3 \mathrm{~A}$ apresenta os dados em uma distribuição contínua em gráfico circular, estando representado também o rumo do vetor médio (este sem relação com sua magnitude) e fornecendo os valores da magnitude do vetor, valor do vetor médio e desvio padrão angular.

Na figuras $3 \mathrm{~B}$ e $\mathrm{C}$ estão os resultados obtidos com a aplicação do método proposto por Pincus (1956), com intervalos de $10^{\circ}$ e uma rotação de $5^{\circ}$.

Os diagramas confeccionados em intervalos de $30^{\circ}$, em 6 configurações diferentes, a partir das rotações de $5^{\circ}$, estão apresentados na figuras $4 \mathrm{~A}$ a F.

Os resultados demostraram que as rotações são úteis, permitindo a obtenção de distribuições com resultados mais próximos dos da distribuição contínua (Figuras $3 A E 4 C)$.

Cabe ressaltar que o procedimento nunca deverá estar dissociado da análise de fácies e de seus processos geradores, o que realmente poderá fornecer uma interpretação mais próxima da realidade. A não observação destas relações tornam o método um simples "artifício", com pouco significado geológico.

Todos os cálculos e desenhos foram realizados pelo programa AZIMED1, desenvolvido pelo autor no Laboratório de Sedimentologia do Instituto de Geociências da Universidade de São Paulo. O programa foi elaborado na linguagem BASIC, versão MS-DOS QBASIC 1.0.

O fluxograma geral do programa está apresentado na figura 5 . Os resultados desta análise estão apresentados e discutidos no item 4.5.2, referente às paleocorrentes da Formação Pirambóia. 


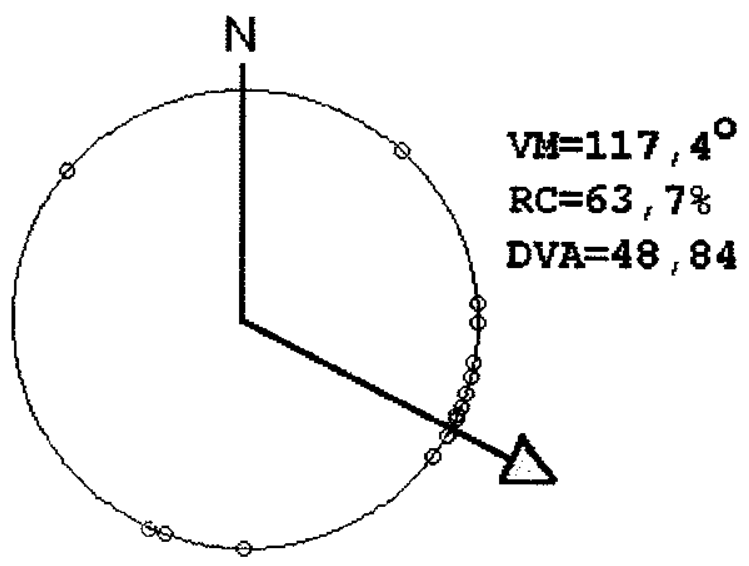

A

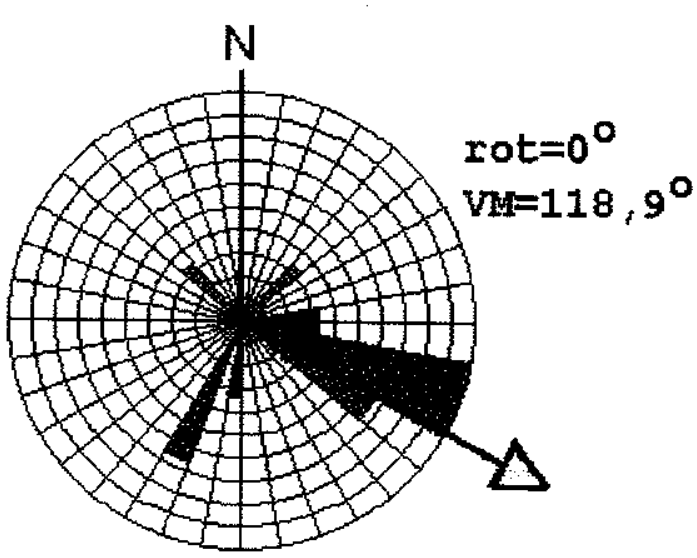

B

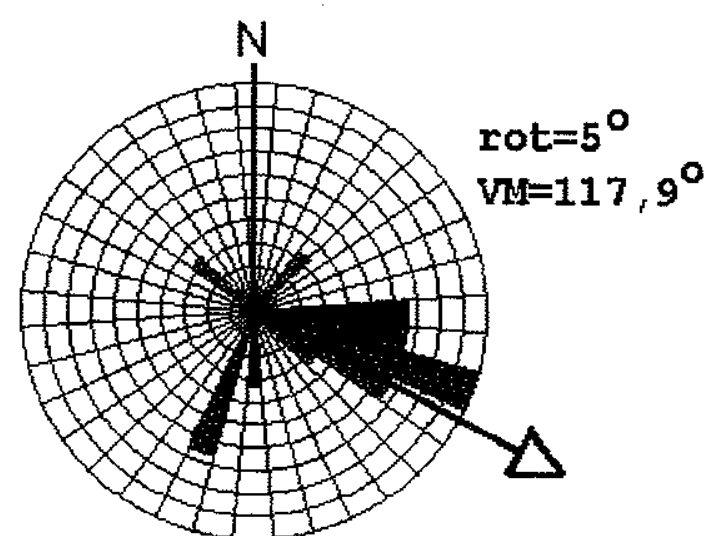

C

Figura 3: $\quad$ A.Diagrama circular com dados de paleocorrentes plotados (๑) em distribuição contínua. B e C. Resáceas com distribuição dos intervalos de $10^{\circ}$ e rotação de $5^{\circ}$.

- número total de dados $=15\left(42^{\circ}, 85^{\circ}, 90^{\circ}, 100^{\circ}, 104^{\circ}, 108^{\circ}, 112^{\circ}, 114^{\circ}, 115^{\circ}, 120^{\circ}, 126^{\circ}, 180^{\circ}, 200^{\circ}, 204^{\circ}, 310^{\circ}\right)$. 


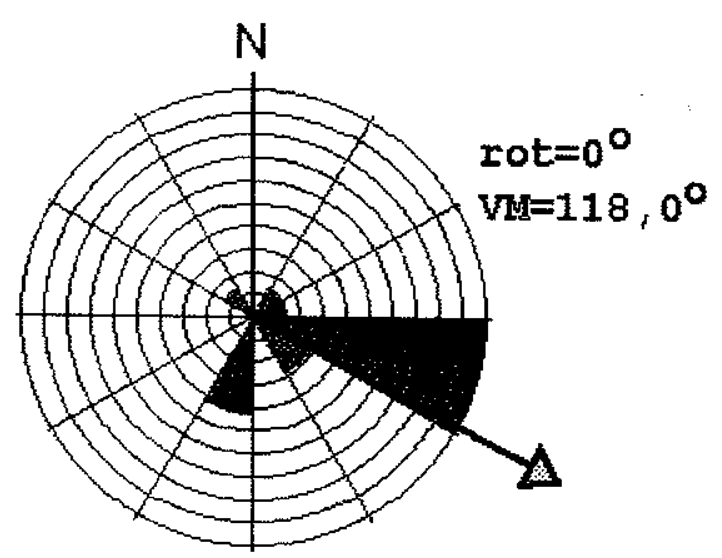

A

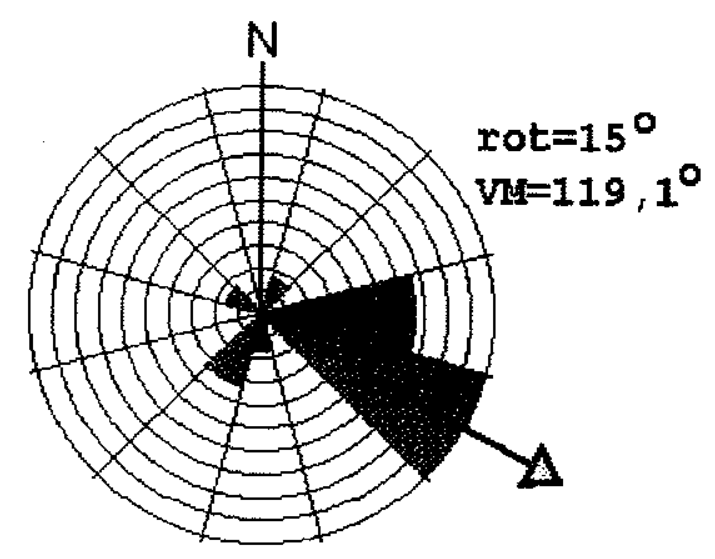

D

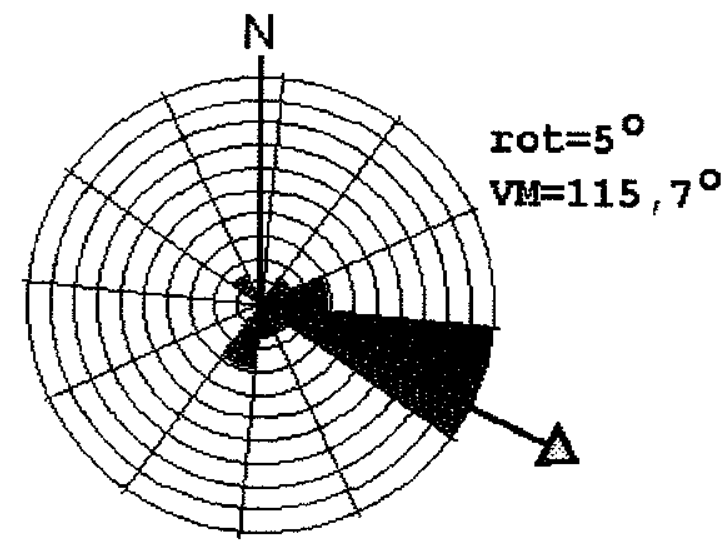

B

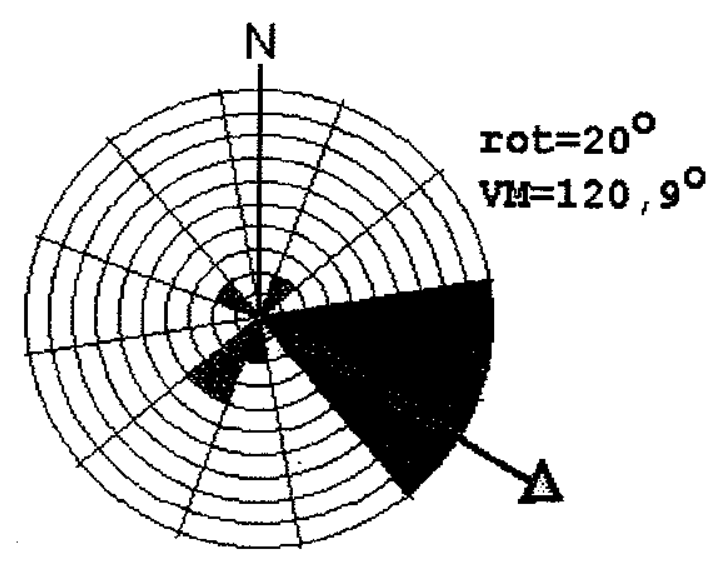

E

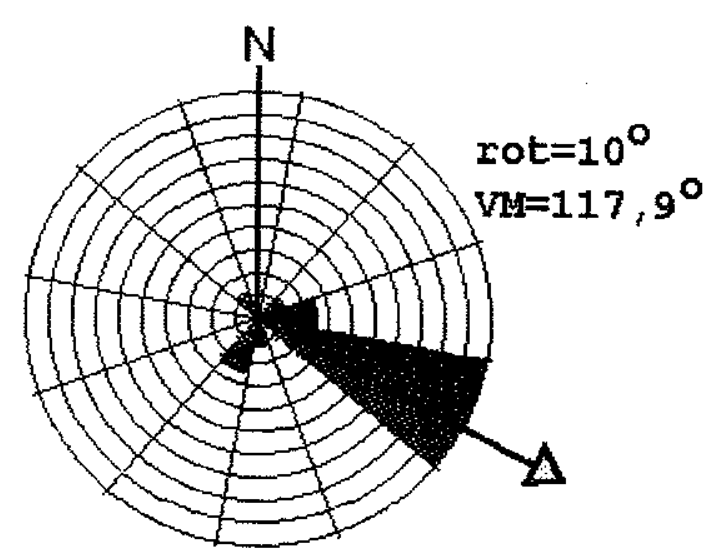

C

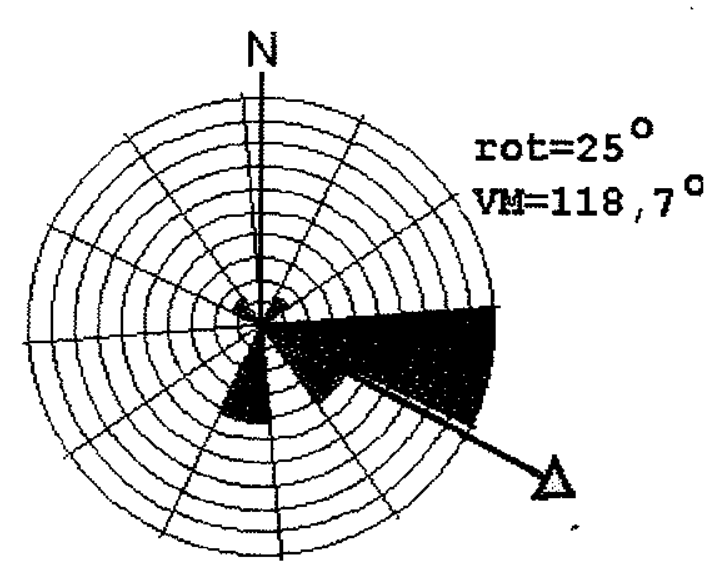

F

Figura 4: $\quad$ Rosáceas com distribuição dos dados de paleocorrentes em intervalos de $30^{\circ}$ e rotações de $5^{\circ}$. (rot = rotação em graus; $V M=$ vetor médio) 


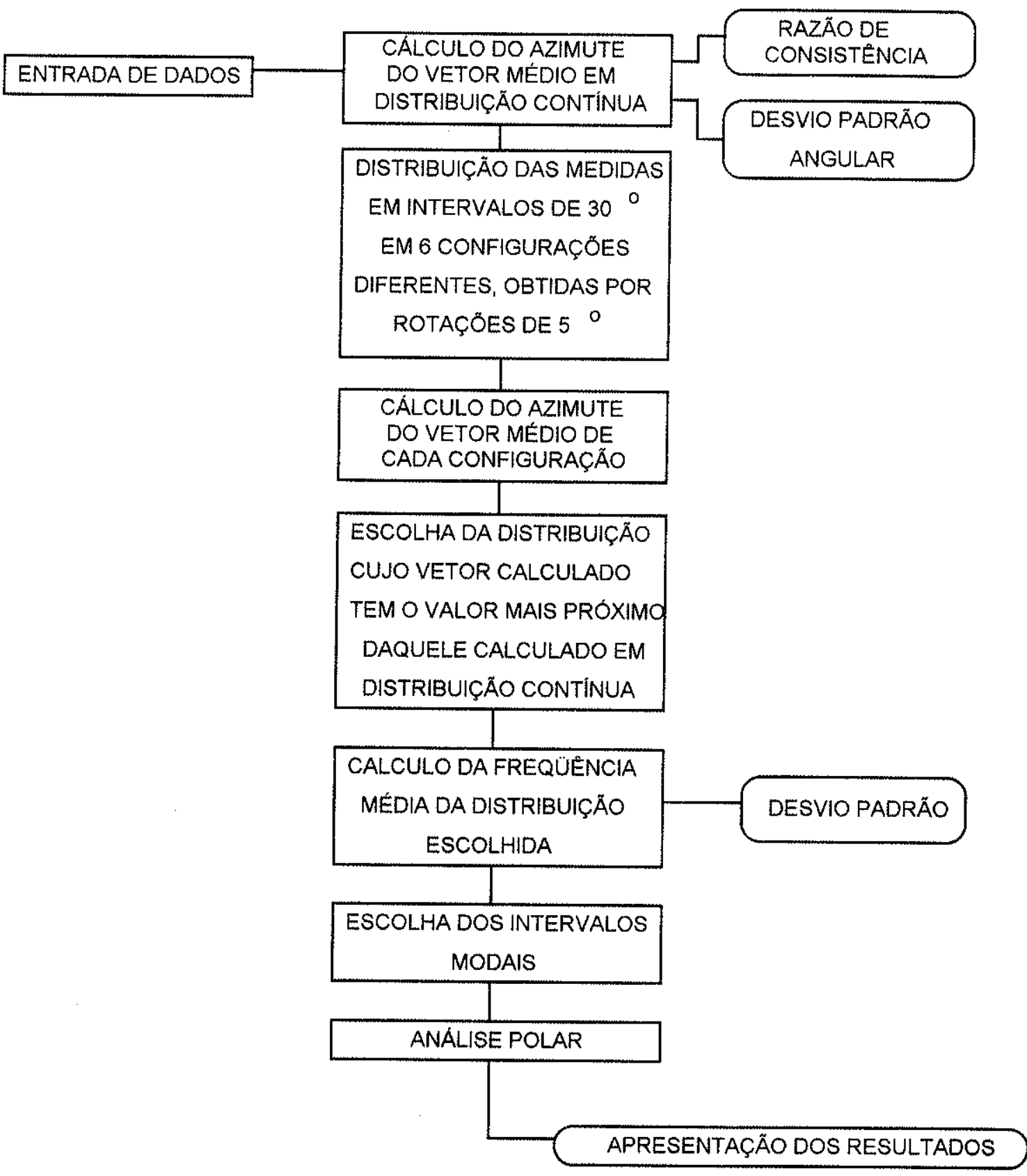

Figura 5: Fluxograma geral do programa AZIMED1, utilizado no tratamento dos dados de paleocorrentes 


\subsubsection{Determinação de argilominerais}

O estudo de argilominerais visou a obtenção de dados para complementação das informações sobre as rochas estudadas. Os métodos analíticos utilizados na identificação de argilominerais foram: difratometria de raios $\mathrm{X}$ e microscopia eletrônica de varredura.

A identificação de argilominerais é considerada ferramenta importante em caracterizações ambientais (e.g. Millot 1970), climáticas (e.g. Singer 1984) e na análise da evolução diagenética (e.g. Wilson \& Pittman 1977).

Uma das respostas mais importantes buscada na investigação de argilominerais é a definição de sua gênese, se alogênicos (sindeposicionais ou introduzidos após a deposição), preenchendo poros, ou autigênicos (neoformados ou regenerados) em processos diagenéticos.

Argilominerais alogênicos tendem a refletir as condições das áreas-fonte, o agente de transporte e as condições do sítio deposicional. Já os autigênicos refletem principalmente as condições pós-deposicionais (Singer 1984), ou eventualmente do meio deposicional no caso de autígenos precoces.

\subsubsection{Difratometria de raios $X$}

Foram analisadas 21 amostras por difratometria de raios $X$. Na preparação estas foram desagregadas, dispersas em água destilada e sifonadas após duas horas e três minutos de decantação, obtendo-se assim a fração menor que $4 \mu$. Amostras que apresentaram cimentação carbonática (sete no total) foram quebradas em prensa hidraúlica, pulverizadas em moinho de esferas e em seguida tratadas com $\mathrm{HCl}$ (tomando-se o cuidado de se diluir rapidamente o ácido). Estes dois tipos de materiais foram fixados sobre lâminas de vidro.

Três procedimentos foram adotados para a maioria das amostras: natural, exposta à atmosfera de etilenoglicol e aquecida a $500^{\circ} \mathrm{C}$. Estes procedimentos provocam variações na estrutura do argilomineral, permitindo uma identificação mais precisa.

As análises foram executadas em difratômetro de raios $X$ composto por gerador modelo IRIS 6 e goniômetro ZEISS URD6 com motor que permite a aquisição contínua de dados, acoplado a microcomputador. Foi utilizada radiação CuK $\alpha$ e obtidos registros na forma de difratogramas gráficos. A tabela 2 apresenta os resultados obtidos. 


\subsubsection{Microscopia eletrônica de varredura}

Foram analisadas 31 amostras com microscópio de varredura, modelo JEOL JSM T330A, do Instituto de Química da UNESP em Araraquara, sob a supervisão do Prof. Dr. Max Brandt Neto.

O procedimento de obtenção de dados por este método começa com a fixação de fragmento de amostra de aproximadamente $3 \times 4 \mathrm{~mm}$ sobre um cilindro de bronze de $1 \mathrm{~cm}$ de altura por $0,9 \mathrm{~cm}$ de diâmetro com esmalte incolor. Posteriormente vários suportes destes são colocados sobre um disco de alumínio e então são levados para metalização com ouro $24 \mathrm{k}$ (quilates) em vácuo por 2 minutos.

Esta montagem é colocada no microscópio e submetida à observação em monitor de televisão, com aumentos de até dez mil vezes. As imagens selecionadas são então fotografadas.

A microscopia eletrônica de varredura fornece informações sobre a forma do argilomineral, permitindo interpretação genética sobre este. 


\begin{tabular}{|c|c|c|c|}
\hline AMOSTRA & PROCEDÉNCIA & & ARGILOMINERAIS \\
\hline & & raios $X$ & MEV \\
\hline $1 \mathrm{~A}$ & Formação Pirambóia & esmectita; illita; caulinita & \\
\hline $1 \mathrm{~B}$ & Formação Pirambóia & esmectita; illita; caulinita & \\
\hline $1 \mathrm{C}$ & Formação Pirambóia & esmectita; illita; caulinita & \\
\hline $4 \mathrm{~A}$ & Formação Pirambóia & esmectita; illita; mica & \\
\hline $4 \mathrm{~B}$ & Formação Pirambóia & esmectita; illita; mica & \\
\hline $9 \mathrm{~A}$ & Formação Pirambóia & esmectita; illita; caulinita & \\
\hline 9B & Formaçāo Pirambóia & esmectita; illita; caulinita & \\
\hline 15 & Formaçāo Teresina & esmectita; illita & esmectita detritica na forma de plaquetas, com bordas neoformadas \\
\hline 151 & Formaçäo Teresina & esmectita; illita & \\
\hline 1511 & Formaçāo Teresina & esmectita; palygorskita (?) & \\
\hline $15 \mathrm{Na}$ & brechas do contato & esmectita & \\
\hline $15 \mathrm{IVb}$ & brechas do contato & esmectita & esmectita detrítica na forma de plaquetas, com bordas neoformadas \\
\hline $15 \mathrm{~V}$ & brechas do contato & esmectita & \\
\hline 15 VII & brechas do contato & & esmectita detrítica na forma de plaquetas, com bordas neoformadas \\
\hline $15 \mathrm{VIII}$ & brechas do contato & & esmectita detrítica na forma de plaquetas, com bordas neoformadas \\
\hline $15 \mathrm{IX}$ & brechas do contato & esmectita & \\
\hline $15 \times \mathrm{XIV}$ & brechas do contato & & esmectita detrítica na forma de plaquetas, com bordas neoformadas \\
\hline $19 \mathrm{~A}$ & Formação Pirambóia & esmectita; illita & \\
\hline $23 \bar{A} 1$ & Formação Teresina & esmectita; illita & \\
\hline $23 \mathrm{C1}$ & brechas do contato & esmectita; illita & \\
\hline $23 \mathrm{C} 2$ & brechas do contato & esmectita; illita & \\
\hline $23 \mathrm{D}$ & Formação Pirambóia & esmectita; illita & \\
\hline $23 E$ & Formação Pirambóia & esmectita;mica & \\
\hline $23 \mathrm{~B}$ & brechas do contato & esmectita; illita & \\
\hline
\end{tabular}

Tabela 2: Resultados obtidos por difratometria de raios $\mathrm{X}$ e por microscopia eletrônica de varredura (MEV). 


\section{ESTÁGIO ATUAL DE CONHECIMENTO SOBRE O CONTATO PASSA DOIS - PIRAMBÓIA}

As unidades Grupo Passa Dois e Grupo São Bento foram originalmente descritas e definidas no clássico trabalho de White (1908) sobre carvão na Bacia do Paraná. Classificadas então como "séries", compunham o "Sistema de Santa Catarina".

No Estado de São Paulo, os trabalhos da antiga Comissão Geográfica e Geológica, iniciados no final do século XIX, tiveram como um dos principais resultados - Mapa Geológico do Estado de São Paulo na escala 1:2.500.000 (Florence \& Pacheco 1929), onde foi representada a distribuição das unidades da Bacia do Paraná.

Desde então surgiram varias propostas diferentes de divisão e nomenclatura litoestratigráfica, nem sempre baseadas em critérios adequados. Entre os principais fatores que ocasionaram o surgimento de tais propostas estão: a realização de trabalhos em áreas restritas da bacia (principalmente os pioneiros), com conseqüente dificuldade de correlação devido às variações laterais dos depósitos, e a utilização de critérios variados na divisão das unidades. Fator complicador adicional foi a idade dos depósitos, também não consensual, o que contribuiu para a inferência de hiatos muitas vezes por simples correlação com outras bacias.

As dimensões do intervalo estudado, constituído pelas porções finais dos topos das formações Teresina, Corumbataí e Rio do Rasto (Grupo Passa Dois) e as camadas iniciais da base da Formação Pirambóia (Grupo São Bento), não permitiram maiores inferências sobre a divisão litoestratigráfica.

Assim, com o objetivo de evitar a simples reprodução das propostas de divisão e nomenclatura litoestratigráfica existentes, bem apresentadas em vários trabalhos (e.g. Melo e Sousa 1985, Lavina 1991), foi adotada a divisão apresentada por Almeida \& Melo (1981), de abrangência regional e cartografada no Mapa Geológico do Estado de São Paulo em escala 1:500.000 (Bistrichi et al. 1981), somando-se ainda a proposta de Hachiro et al. (1993) para o Subgrupo Irati (Figura 6).

\subsection{As unidades do Grupo Passa Dois}

No Estado de São Paulo a primeira citação conhecida sobre depósitos do Grupo Passa Dois foi feita por Andrada e Silva \& Andrada (1827 apud Baptista et al. 1984), ao referirem-se à "pedra calcárea" às margens do rio Corumbataí. 
A denominação "Folhelho da Estrada Nova" foi empregada pela primeira vez por White (1908), em trabaihos nos estados sulinos, para os folhelhos cinza e variegados, com concreções de sílex, camadas arenosas e restos vegetais, que ocorriam na "estrada nova do Rio do Rasto", entre o "Folhelho preto de Iraty" e o "Calcareo da Rocinha".

As denominações Teresina e Serrinha foram sugeridas por Euzébio de Oliveira (então membro da antiga Comissão Geográfica e Geológica do Estado de São Paulo) e apresentadas por Moraes Rego (1930). Posteriormente, em 1947, Gordon Jr. reformulou a proposta estratigráfica para as formações Estrada Nova e Rio do Rasto, incorporando-lhes respectivamente os termos Serra Alta e Morro Pelado.

Os trabalhos da antiga Comissão Geográfica e Geológica do Estado de São Paulo, resultaram no reconhecimento da unidade Corumbataí, definida por Pacheco (1927), relacionada então à "Série Passa Dois" de White (1908).

Segundo Almeida \& Melo (1981), as unidades em superfície do topo do Grupo Passa Dois, são a Formação Corumbataí, ao norte do divisor de águas dos rios Tietê e Piracicaba, a Formação Teresina, ao sul do referido marco e a Formação Rio do Rasto, representada pelo Membro Serrinha, que aflora na porção sul do Estado, nas imediações das cidades de Fartura e Sarutaiá. As unidades supracitadas foram assim descritas por aqueles autores:

a) Formação Corumbatai - apresenta em sua porção inferior argilitos, siltitos e folhelhos cinzentos a roxo-acinzentados, seguindo-se uma sucessão de camadas de argilito e arenito. Ocorrem também bancos e lentes de calcário. As estruturas sedimentares mais freqüentes são estratificações plano-paralelas e cruzadas de baixo ângulo, laminação flaser, marcas onduladas e gretas de contração. O uso do termo Corumbataí na denominação destes depósitos foi justificado pela impossibilidade de individualização dos depósitos correspondentes às unidades Serra Alta e Teresina. Os contatos da Formação Corumbataí foram considerados concordante com o topo da unidade Irati e erosivo com a base da Formação Pirambóia. Na unidade ocorrem bivalves, ostracodes, conchostráceos, peixes e restos vegetais.

b) Formação Teresina - caracteriza-se pela alternância de lâminas ou camadas de folhelhos, argilitos, siltitos e por vezes calcários. Apresenta como estruturas sedimentares mais comuns marcas onduladas, gretas de contração, laminação flaser e laminação plano-paralela. São transicionais os contatos com as formações Serra Alta (sotoposta) e Rio do Rasto (sobreposta). O contato com a base da Formação Pirambóia tem sido considerado erosivo. Os fósseis reconhecidos nesta unidade foram bivalves, restos de peixes, conchostráceos, ostracodes, plantas e palinomorfos. 


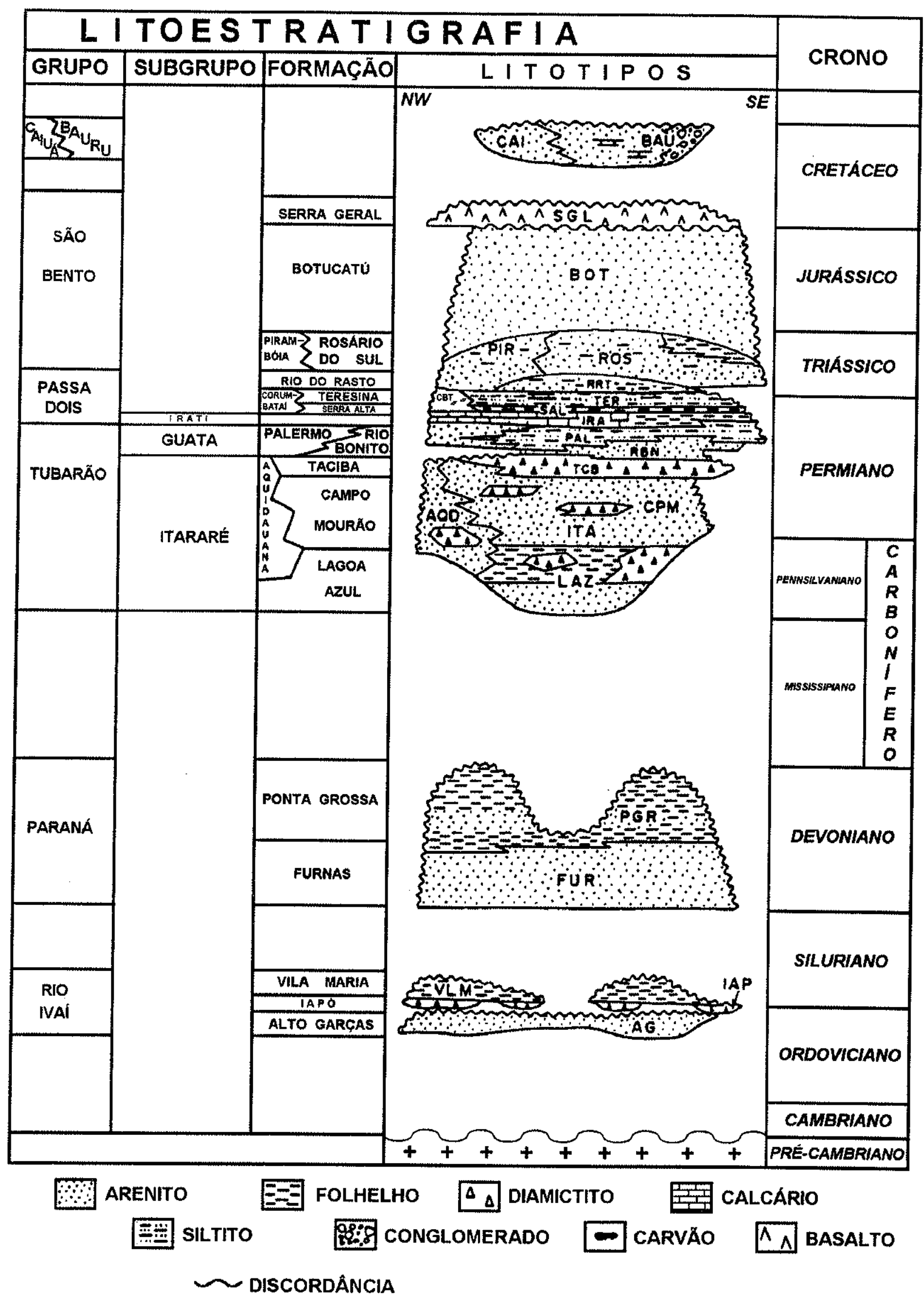

Figura 6: $\quad$ Divisão litoestratigráfica adotada para a Bacia do Paraná (modificada de Almeida \& Melo 1981, Lavina 1991, Hachiro et al. 1993 e Milani et al. 1994). 
c) Formação Rio do Rasto, Membro Serrinha (membro inferior) compreende uma sucessão de arenitos muito finos e siltitos, de cores esverdeadas, passando a avermelhadas no topo. Intercalam-se nestes litotipos folhelhos, arenitos de granulação média e calcários oolíticos ou estromatolíticos. As estruturas encontradas são estratificações plano-paralelas e cruzadas de baixo ângulo e laminação flaser. Ocorrem bivalves, conchostráceos, ostracodes, restos de peixe e de plantas e palinomorfos.

\subsection{A Formação Pirambóia}

As primeiras tentativas de divisão da unidade Botucatu, tal como definida por Gonzaga de Campos (1889), aparecem nos relatórios da Comissão Geográfica e Geológica do Estado de São Paulo dos anos de 1916 e 1917 (Comissão Geográfica e Geológica do Estado de São Paulo 1917 e 1918 respectivamente), onde a parte inferior foi denominada "grez de Pirambóia", superposta às "Camadas de Corumbataí" e sotoposta ao "grez de Botucatu".

Pacheco (1927) definiu a unidade "grez de Pirambóia" como unidade exclusivamente arenosa que constituiria a porção inferior do "Triássico" no Estado de São Paulo.

A primeira descrição com aspectos distintivos entre as unidades Pirambóia e Botucatu verifica-se em Oliveira (1930 - atribuída por aquele autor a Joviano Pacheco) onde o "Arenito Botucatu" foi descrito como arenito grosso, sem argila, vermelho e com "grânulos bem rolados" de quartzo e "mal rolados" de feldspato e o "Arenito Pirambóia" como arenito fino, sem feldspato e "claramente argiloso em vários locais".

O trabalho de Soares (1973) constituiu importante avanço nos estudos da Formação Pirambóia no Estado de São Paulo, com a caracterização da formação nos seus aspectos texturais e estruturais, reconhecendo a partir disso duas fácies, uma de canal fluvial e outra de transbordamento.

A Formação Pirambóia, que no Estado de São Paulo faz contato com os topos das unidades Corumbataí, Teresina e Serrinha, foi descrita por Almeida \& Melo (1981) como uma sucessão de camadas arenosas, avermelhadas ou rosadas, constituídas por arenito de granulação fina e média, possuindo maior proporção de fração argilosa na porção inferior. Foram destacadas estratificações plano-paralelas e cruzadas tangenciais na base, de médio a grande porte. Quanto ao conteúdo fossilifero, foram reconhecidos conchostráceos, ostracodes, escamas de peixes e restos vegetais.

Alguns autores (e.g. Washburne 1930, Soares 1973) apontaram, na Formação Pirambóia no Estado de São Paulo, a presença de intervalo basal, constituído por brechas, sobreposta às unidades Teresina, Corumbataí e Serrinha. 
Para meihor articulação e compreensão do texto, esta camada foi tratada separadamente (Item 4.4), recebendo a denominação de brechas do contato, representando então o "regolito fóssil", "solo fóssil" ou "brecha" nas denominações correntes.

\subsection{Idades dos depósitos}

Os sedimentos do topo do Grupo Passa Dois foram considerados de idade neopermiana (e.g. White 1908, Pacheco 1927, Daemon \& Quadros 1970, Zalán et al. 1990, Lavina 1991, Rohn 1995), existindo também opiniões sobre sua deposição durante o Mesozóico (e.g. Du Toit 1927, Moraes Rego 1930, Oppenheim 1935, Ragonha 1984 e 1989, Cunha \& França 1993) e ainda, em menor número, a admissão de idade permiana média ou mais antiga (e.g. Sanford \& Lange 1960). Para Almeida \& Melo (1981), as unidades Corumbataí, Teresina e Serrinha teriam idade kazaniana. Porém, os fósseis conhecidos das unidades do Grupo Passa Dois ainda não foram suficientes, do ponto de vista qualitativo, para o estabelecimento de idades mais confiáveis, principalmente no Estado de São Paulo.

Dipnóis das formações Teresina e Corumbataí, foram considerados por Ragonha (1989), em comparação com exemplares da Índia e Europa, como triássicos. Também foram utilizados por aquele autor Ceratodus e Xenacantódios como evidências adicionais para a idade proposta.

Lavina (1991) considerou totalmente permianas as unidades do topo do Grupo Passa Dois, baseado principalmente em tetrápodes fósseis encontrados na unidade Rio do Rasto e na Formação Sanga do Cabral (do grupo São Bento e considerada contemporânea), correlacionáveis com espécimes de bacias africanas (que apontam para tais idades).

Rohn \& Lavina (1993) apontaram como argumentos para manutenção da unidade Passa Dois integralmente no Permiano as presenças de tetrápodes no topo da Formação Rio do Rasto; flora glossopteridea, esfenófitas, licófitas e gimnospermas; bivalves; placas dentárias de Dipnois; palinomorfos; somando-se aspectos da história deposicional do grupo.

O palinólogo Roberto F. Daemon (informação verbal, 1993), baseado em dados fornecidos por palinomorfos, afirmou, em debates do Primeiro Simpósio sobre a Cronoestratigrafia da Bacia do Paraná, que o topo da Formação Rio do Rasto, na Serra do Cadeado, teria idade eotriássica.

A Formação Pirambóia no Estado de São Paulo, tida como mesozóica, não apresentou até o momento fósseis que fornecessem idades confiáveis e precisas. Sua idade tem sido inferida através de suas relações com o topo das unidades com as 
quais mantém contato (formações: Rio do Rasto, Teresina e Corumbataí) e com a base da unidade Botucatu. A unidade Botucatu, porém, tem apenas seu topo com idade estimável, devido ao contato com os derrames basálticos da Formação Serra Geral, estes datáveis por isótopos. Também tem sido usada a correlação com as unidades de outras porções da bacia como o Grupo Rosário do Sul. Assim, a deposição da unidade Pirambóia pode estar inserida em algum intervalo de tempo compreendido entre o Eotriássico e o Neojurássico.

Souza et al. (1971) descreveram fragmentos de Licopodiopsis derbyi na Formação Pirambóia próximo do contato com a Formação Corumbataí. Tal achado indicaria idade permiana para os depósitos, porém, indícios de transporte em alguns fragmentos e presença no mesmo jazigo de conchostráceos e ostracodes (Cypridea), tidos por aqueles autores como indicativos de idade transicional entre o Jurássico e o Cretáceo, tornaram o achado um problema. Este assunto foi retomado por Fúlfaro (1972), o qual considerou a presença de fragmentos de Licopodiopsis indicação de um intervalo de tempo menor entre o final da deposição Passa Dois e início da deposição Pirambóia. Outros autores limitaram-se apenas a citação do achado. No presente trabalho năo foram encontrados elementos que pudessem oferecer solução para tal problema.

Lavina (1991) considerou a unidade Pirambóia permiana pela correlacão com a unidade Sanga do Cabral e as relações de contato com a Formação Rio do Rasto.

Estas incertezas quanto as idades dos depósitos têm afetado a questão do contato Passa Dois-Pirambóia, principalmente no Estado de São Paulo, resultando no estabelecimento de largos hiatos (erosivos e/ou deposicionais) na tida discordância entre as unidades Passa Dois e Pirambóia. Estes hiatos inferidos chegam a variar entre alguns milhões de anos (e.g. Soares 1973; Zalán et. al. 1990) até quase uma dezena de milhões de anos (Rohn 1995), o que tentar-se-á demonstrar pouco provável. 


\section{UNIDADES PRESENTES NO INTERVALO ESTUDADO}

O intervalo estudado constituiu-se das porções superiores das unidades Corumbataí, Teresina e Serrinha e da base da Formação Pirambóia.

\subsection{Formação Corumbataí}

\subsubsection{Litotipos}

A Formação Corumbataí ocorre ao norte do divisor de águas dos rios Tietê e Piracicaba e constitui-se, em sua porção superior, de pelitos, pelitos arenosos, arenitos finos e subordinadamente micritos (mudstone), micritos fossilíferos (wackestones) e rochas mistas (silicosas e carbonáticas).

Os sedimentos finos (pelitos, pelitos arenosos e calcilutitos) da Formação Corumbataí formam camadas tabulares com espessuras de até $2 \mathrm{~m}$ e ainda lâminas e lentes, que intercaladas com arenitos finos ou calcarenitos, constituem estratificações dos tipos flaser, wavy e lenticular. Predominam cores vermelha, marrom, roxa e amarela.

Nos pelitos e calcilutitos predomina a estratificação plano-paralela. Em arenitos finos e calcarenitos ocorrem laminações dos tipos plano-paralela, cruzada ou ondulada.

$\mathrm{Na}$ região de Santa Luzia, Município de Charqueada, em afloramento correspondente à porção média a superior da Formação Corumbataí (aproximadamente 10 metros abaixo do contato com a Formação Pirambóia), Riccomini et al. (1992) descreveram um enxame de diques clásticos de arenito fino, com espessuras variando entre 15 e 40 centímetros, em pelitos. A existência de ramificações rumo ao topo dos diques bem como de dobras de arrasto nos sedimentos encaixantes seriam conseqüência, segundo os autores, de um mecanismo de injeção forçada de sedimentos liquefeitos, de baixo para cima, por abalos sísmicos (na eodiagênese). Ainda nesta região, foram observadas lentes centimétricas de brecha intraformacional constituída por fragmentos irregulares de calcilutito, imersos em matriz também carbonática.

\subsubsection{Fósseis}

Durante a presente pesquisa não foram observados fósseis próximos ao contato Passa Dois-Pirambóia. 


\subsection{Formação Teresina}

\subsubsection{Litotipos}

Calcilutitos, caicarenitos, pelitos, pelitos arenosos, arenitos finos e sedimentos mistos (silicosos e carbonáticos), formam o conjunto de litotipos mais freqüentes no topo da Formação Teresina.

As rochas pelíticas e pelíticas arenosas constituem camadas tabulares de até 2 metros ou lâminas e lentes intercaladas com arenitos finos, compondo, por vezes, estratificações dos tipos flaser, wavy e lenticular, semelhantes às da Formação Corumbataí. A estrutura interna mais comum é a laminação plano-paralela, que tornase menos distinta quanto mais argilosa a rocha. Camadas e lâminas gretadas constituem feições freqüentes. Também foram encontradas marcas onduladas assimétricas.

Arenitos muito finos dispõem-se em camadas tabulares, podendo apresentar como estruturas internas estratificações plano-paralela, cruzada, ondulada ou ainda truncada por ondas.

Os calcarenitos são constituídos por carapaças de ostracodes (Prancha 1 fotos 1,2 e 3) e menos freqüentemente, bivalves e gastrópodes. Na região dos municípios de Taguaí e Fartura, ocorrem camadas de ooesparitos (grainstones) intercaladas com lâminas ou lentes de micrito (mudstones).

Os calcilutitos mais comuns são micritos, micritos com fósseis (mudstones) que constituem camadas tabulares, lâminas e lentes. Laminação plano-paralela é a estrutura interna mais comum, ocorrendo também gretamentos.

Microbialitos (termo proposto e definido por Burne \& Moore 1987) são depósitos organo-sedimentares que crescem devido à atividade de comunidades microbianas bentônicas, por aprisionamento de partículas ou indução de precipitação mineral. Foram observados na região de Taguaí (Prancha 1 - Foto 4). Microbialitos com laminação parcialmente (arqueada) ou quase totalmente deformadas ou rompidas (Prancha 1 - Foto 5), ocorrem na região compreendida entre os quilômetros 165 e 168 da Rodovia Castelo Branco (SP 280) e nas proximidades da cidade de Conchas.

É comum a intercalação de camadas de espessuras centimétrica a decimétrica de sílex maciço nos carbonatos. Entretanto, formas diferentes e raras mereceram destaque por serem importantes nas interpretações paleoambientais.

Nos quilômetros 165; 166,5 e 168 (respectivamente pontos 07, 15 e 18) da Rodovia Castelo Branco (SP 280) e na Rodovia Mal. Rondon (SP 300), próximo à sede do município de Conchas (ponto 63), observou-se camadas tabulares, com espessuras 
centimétricas (máxima de $10 \mathrm{~cm}$ ), compostas por "seixos" e "grânulos" arredondados de sílex com formatos variando entre discóide e esférico (Prancha 2 - Fotos 6, 7 e 8), revestidos por cristais de calcita e com poros preenchidos por cimento esparítico e por sílica fibrorradiada (Prancha 2 - Foto 9). Tal textura foi denominada pé-de-moleque.

O silexito pé-de-moleque está intercalado entre camadas pelito-carbonáticas. Na ocorrência do quilômetro 168 (ponto 18), a camada de silexito pé-de-moleque está afetada por diques verticais de material silicificado que a deformaram ou romperam. Estes diques, provavelmente injeções de material sedimentar de origem ainda não totalmente esclarecida, cortaram a camada de pelito sobreposta (Prancha 2 - Fotos 6 e 10) e provavelmente provocaram a deformação já silicificados. Tal injeção pode ter origem semelhante à aquela (ligada a evento sísmico) dos diques descritos por Riccomini et al. (1992) na Formação Corumbataí. Várias outros conjuntos de diques foram descritos em porções mais inferiores da Formação Teresina por Melo e Sousa (1985).

Outra forma particular de silex encontra-se a $10 \mathrm{~km}$ ao $\mathrm{W}$ da sede do município de Anhembi (porção central do Estado de São Paulo), em estrada de terra, que margeia o reservatório de Barra Bonita, em direção a Botucatu. As ocorrências estão divididas pelo vale do ribeirão do Retiro. Os corpos apresentam formas cônica ou de tronco de cone, com alturas entre 0,5 e 1,5 metro e diametros entre 0,2 e 1 metro. São constituídos de sílex e apresentam zoneamento, sendo mais maciças nas porções externas e com porosidade vesicular na porção mais interna, esta última com formato cilindrico. Freqüentemente esta porção central de corpos partidos, apresenta porosidade vesicular (Prancha 3 - Foto 11). Na grande maioria dos casos o cilindro central é visivel no topo, ocorrendo com menor freqüência mais de um cilindro no topo e/ou na lateral (Prancha 3 - Foto 12). Alguns corpos apresentam ainda porções internas ocas, com forma de abóboda, observadas em corpos fragmentados no sentido longitudinal (Prancha 3 - Foto 13). São comuns estruturas "geminadas", com dois ou mais corpos compartilhando a mesma base. (Figura 7). A distribuição destes corpos aparenta ser caótica. Os corpos de formato cônico apresentam tendência a romperemse próximo à base exposta, dando origem a corpos de forma de tronco de cone. Até $2 \mathrm{~m}$ abaixo da "laje" de sílex foram observados pelitos cimentados por sílica. Os corpos apresentam continuidade abaixo da superfície atual, o que indica dimensões maiores do que as observadas. 


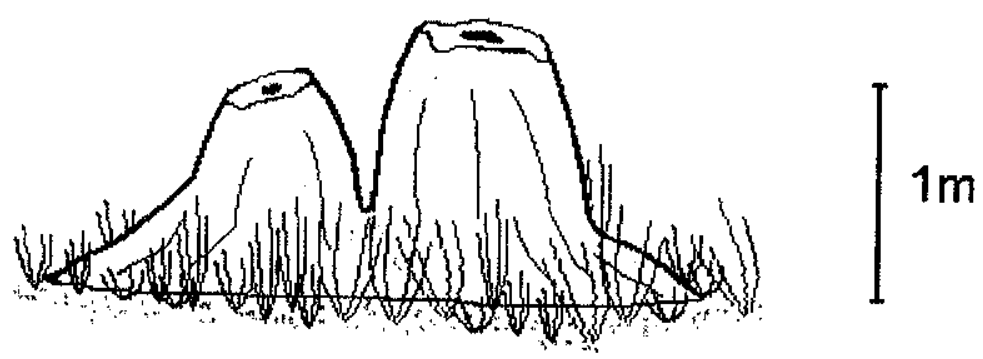

Figura 7: Gravura representando corpos geminados, compartilhando a mesma base, $10 \mathrm{~km}$ a oeste de Anhembi, próximo ao vale do Ribeirão do Retiro, SP.

Observações em cortes de amostra (Prancha 3 - Foto 14) e seções em microscópio (Prancha 3 - Foto 15) revelaram a existência de uma massa de quartzo microcristalino com veios ou bolsões de quartzo fibrorradiado. Ocorrem ainda nódulos silicosos acinzentados. Estas características são comuns a todas as porções externa e interna dos cones e à camada de silex na base destes, sendo entretanto os veios e bolsões de quartzo fibrorradiado mais comuns no cone central e os nódulos silicosos na camada basal de onde os cones emergem. A origem destas estruturas está apresentada e discutida no item 7.5 .

Uma brecha intraformacional foi observada no quilômetro 165 da Rodovia Castelo Branco (SP-280), na forma de camada com espessura centimétrica, intercalada entre camadas de micrito fossilifero (wackestones) e constituída por fragmentos de conchas de bivalves, fragmentos de sílex e matriz esparítica. Assemelha-se às descritas por Fúlfaro (1970) na região de Angatuba.

Em subsuperfície as porções do topo da Formação Teresina, descritas a partir de testemunhos por Roncarati (1971), não diferenciam-se das observadas em afloramentos, excetuando-se o predomínio da cor verde.

\subsubsection{Fósseis}

Das ocorrências fossilíferas detectadas durante as atividades de campo, mereceu destaque um fragmento petrificado de espécime de Pteridófita, ordem Marattiales, encontrado próximo do topo da unidade Teresina no $\mathrm{km} 165$ da Rodovia Castelo Branco sentido capital-interior (corte à direita).

O fóssil constitui-se de fragmento de caule, silicificado, de cor cinza escura, onde foi possivel observar, tanto em cortes longitudinais como transversais (Prancha 4 - Fotos 16 e 17), estruturas indicativas do sistema vascular. A complexidade deste fragmento de estelo, com vários vasos condutores de seiva em forma de " $C$ " (Prancha 4 - Foto 16), aponta para porções médias a superiores do caule. Por se tratar de espécime pouco deformado e sendo conhecida a relativa fragilidade física deste 
gênero de vegetal, considerou-se que eles dificilmente resistiriam a transporte e exposição muito prolongados, sendo provável que sua silicificação tenha ocorrido logo depois de sua morte e após curto transporte. Esta silicificação, a qual conservou estruturas bastante delicadas, deve ter sido possivel na presença de sílica relativamente abundante no ambiente onde o vegetal foi permineralizado. Tais condições foram reconhecidas por Mussa \& Coimbra (1984) em estudos de espécimes lenhosos permianos da Formação Teresina, onde o ambiente era de águas rasas com alta concentração de sílica, evidenciada por estruturas que indicam rápida precipitação.

Devido ao fragmento estudado representar apenas pequena porção do caule do vegetal, não foi possível classificá-to como Psaronius ou como Tieteia, pois não foram observados elementos distintivos, tais como aqueles apresentados nos trabalhos de Solms-Laubach (1913) e Derby (1915). A classificação seria possivel em seção completa do caule, já que a forma do caule e a distribuição dos vasos condutores de seiva constituem importantes características distintivas.

Cabe aqui a observação de que o espécime, com o qual Solms-Laubach (1913) identificou a espécie Tieteia singularis, provém de lugar próximo a cidade de Tietê, região onde geralmente são descritos sedimentos da unidade Itararé (e.g. Bistrich et al. 1981), indicando a possibilidade de imprecisões nas referências que apontam tais exemplares como pertencentes à unidade Corumbataí (e.g. Mezzalira 1989).

Considerou-se o presente achado relevante devido a sua localização mais a sul, já em sedimentos da Formação Teresina e por sua ocorrência próxima à rocha com restos de "licófitas" (Prancha 4 - Foto 18), estas observadas também por Röesler et al. (1985). Outra ocorrência atribuida ao gênero Tieteia foi descrita por Landim (1970), em sedimentos da Formação Corumbataí, ao norte de Batovi, na antiga Parada Camaquã da linha de trem que ligava Rio Claro a Itapé, hoje desativada.

Outra ocorrência de psaronídeos foi coletada por Jorge Hachiro (informação verbal, 1992) em sedimentos fluviais do "Conglomerado Ibicatu" (Hachiro 1991), sotopostos ao Subgrupo Irati.

Outros fósseis observados foram: conchas silicificadas de bivalves correlacionáveis a gêneros do Permiano marinho da Austrália (Rocha Campos et al. 1990), com possivel atribuição aos gêneros Pyramus Dana e Vacunella Waterhouse e ostracodes não determinados. 


\subsection{Formação Rio do Rasto, Membro Serrinha}

\subsubsection{Litotipos}

O Membro Serrinha foi identificado somente na região entre os municípios de Fartura e Sarutaiá. Na estrada que liga aquelas cidades, nas proximidades do contato entre a Formação Pirambóia e o Membro Serrinha, ocorrem neste último, siltitos e argilitos róseos a avermelhados, com estratificação lenticular e extremamente bioturbados, além de micritos com ostracodes. Neste setor destaca-se a presença de um nivel silicificado com cerca de $40 \mathrm{~cm}$, com estrutura parecida a micro-cárstica.

\subsubsection{Fósseis}

Ocorrem ostracodes e fragmentos de bivalves. Pequeno pedaço $(15 \mathrm{~cm}) \mathrm{de}$ espécie lenhosa silicificada foi coletado por Jorge Hachiro (informação verbal, 1992). Osso de tetrápode foi observado por Armando Márcio Coimbra (informação verbal, 1993)

\subsection{Brechas presentes no contado Passa Dois-Pirambóia}

\subsubsection{Conhecimento atual}

O primeiro registro conhecido sobre a presença de uma camada de brecha na base do Grupo São Bento foi feito por Washburne (1930), o qual a descreveu como "solo com seixos" formado por "derrocada" da parte superior da Formação Corumbataí. Este intervalo constituiria evidência de inconformidade na base do "arenito Botucatu".

Almeida \& Barbosa (1953), em estudos nas regiões de Piracicaba e Rio Claro, definiram a base da "Série São Bento" como marcada por um "solo fóssil", com fragmentos angulosos de diversos tamanhos, compreendendo sílex, arenitos e folheihos da Formação Estrada Nova, subjacente, imersos em matriz vermelha ou manchada de branco, areno-argilosa, não estratificada e sem qualquer arranjo mais definido.

Almeida (1954) descreveu o contato da unidade Pirambóia com as camadas permianas como uma superfície plana. Reconheceu na base do Pirambóia uma "fácies coluvial" constituída por regolito fóssil, quase sempre presente no Estado de São Paulo.

Fúlfaro (1970) identificou depósitos de brecha na base da Formação Pirambóia na região da Serra de Angatuba, repousando discordantemente sobre o 
topo da Formação Teresina. Estes depósitos de brecha constituiriam-se, segundo aquele autor, de fragmentos de siltito amarelado e subordinadamente por silex, imersos em matriz areno-argilosa vermelha.

Soares (1973) apontou o "regolito fóssil" quase sempre presente no contato Passa Dois - Pirambóia, exceto nas regiões ao sul de Jacirendi, a oeste de Piraçununga, a leste de Anhembi e a oeste de Rio Claro, onde haveria contatos planos entre siltitos da Formação Corumbatai e arenitos da Formação Pirambóia.

Ainda segundo Soares (1973), o "regolito fóssil" seria constituído, no quilômetro 166,5 da Rodovia Castelo Branco (SP-280), por fragmentos tabulares e angulosos com incipiente imbricamento na base, compostos de siltito semelhante ao do topo da Formação Teresina, e ainda fragmentos não totalmente destacados do topo desta formação. Os $40 \mathrm{~cm}$ superiores da brecha teriam se formado pela ação de correntes aquosas que retrabalhara o regolito.

\subsubsection{Litotipos}

As brechas do contato Passa Dois-Pirambóia são semelhantes em todas as exposições estudadas, independentemente da formação sotoposta (Corumbataí, Teresina ou Rio do Rasto) e compõem-se da alternância de estratos decimétricos e tabulares (em escala de afloramento) de brechas com camadas interbrechas pelíticas ou calcilutíticas.

As camadas de brechas são constituídas por fragmentos com formas irregulares a tabulares, decimétricos a subcentimétricos, com cores esbranquiçadas a arroxeadas (estes últimos em porções mais alteradas), compostos por material semelhante ao das rochas com as quais se intercalam, além de silex, imersos em matriz de cor vermelha (Prancha 5 - Fotos 19 e 20), lulítica (predominantemente argilosa), Os fragmentos não apresentam um arranjo definido, ocorrendo, algumas vezes, discreta tendência à orientação . apresentando eventuais preenchimentos por cimento carbonático (Prancha 6 - Foto 24), podendo existir calcitas de até $0,4 \mathrm{~cm}$. As brechas, apesar de constituírem, em sua maioria, camadas tabulares com certa regularidade na espessura, não apresentam no seu interior, lateral ou verticalmente, arranjo ou distribuição definiveis

As camadas interbrechas podem ser constituidas por carbonatos (bioesparitos, biomicritos, micritos, micritos fossiliferos), pelitos e pelitos arenosos ou ainda rochas mistas (silicosas e carbonáticas), apresentando fraturas preenchidas por calcita.

Os seguintes tipos de contatos ocorrem entre as camadas que compõem este pacote: (1) abruptos entre camadas de brechas e camadas interbrechas; (2) contatos transicionais entre os topos de camadas interbrechas e bases de camadas de brechas, com fragmentos "destacando-se" do topo das camadas de interbrechas (Prancha 5 - 
Fotos 21); (3) contatos abruptos entre camadas de brecha. As espessuras destas sucessões de estratos apresentam variações dentro da área estudada.

Rumo ao topo, cessam as intercalações com outros litotipos, seguindo-se uma gradação aparente entre brecha e arenito pelítico (Prancha 5 - Fotos 22 e 23). Há, além da diminuição progressiva na freqüência, também uma diminuição progressiva no tamanho dos fragmentos. A matriz também sofre mudanças, tornando-se progressivamente mais arenosa. Em sua porção de topo, ausentam-se os intraclastos, restando apenas arenito pelítico (Prancha 5 - Foto 23).

Em subsuperfície, as brechas do contato, segundo as descrições de testemunhos apresentadas por Roncarati (1971) e Thomaz Filho (1972), apresentam muitas das características texturais observadas em afloramentos, principalmente a variação da base para o topo, ou seja, a diminuição na quantidade e redução do tamanho dos clastos e passagem da matriz pelítica para arenosa. Diferenciam-se, contudo, quanto a cor predominantemente verde na maioria dos poços (PAA-1; PAA-2; PAA-3; PAA-4; PAA-7; PAA-8; PAA-9; PAA-10) e quanto a presença de nódulos de pirita (PAA-2; PAA-8; PAA-9), que aparecem tanto nas camadas de brechas, como nas camadas interbrechas. De todas as perfurações profundas executadas no Estado de São Paulo a única que documentou brechas no contato Passa Dois-Pirambóia foi a sondagem de Mandaçaia (1-MA-1-SP), entre as cidades de Avaré e Santa Barbara a aproximadamente $500 \mathrm{~m}$ de profundidade (cota $85 \mathrm{~m}$ ). Esta ocorrência é a mais afastada, até o momento notificada, em relação a faixa de afloramentos das rochas permo-triássicas.

As brechas do contato estão ausentes nas imediações das cidades de Charqueada (ponto 37), Batovi (ponto 14), onde ocorre o contato direto entre pelitos da formação Corumbataí e arenitos da Formação Pirambóia, e a oeste da cidade de Anhembi (poços PAA-10 e PAA-11) onde ocorre o contato direto entre pelitos e arenitos respectivamente pertencentes às formações Teresina e Pirambóia.

\subsubsection{Fósseis}

Ocorrem nas camadas interbrechas carapaças de ostracodes (micritos com fósseis), tabém presentes em intraclastos das brechas (Prancha 6 - Foto 25).

\subsection{Formação Pirambóia}

\subsubsection{Litotipos}

A unidade Pirambóia apresenta-se em contato abrupto, plano e horizontal com 
as brechas sotopostas. Sua porção basal é constituída por arenitos médios e finos, moderado a bem selecionados, com grãos subarredondados. Constituem camadas de espessura métrica, com superfícies de truncamento que delimitam corpos de geometria cuneiforme (em corte) (Prancha 6 - Foto 26); internamente as camadas são laminadas, na forma cruzada do tipo tangencial na base.

Sobreposta e em contato abrupto com a camada anterior, ocorre estrato de arenito com espessura entre 1 e $3 \mathrm{~m}$; a granulação é de areia média e fina, seleção moderada; a estrutura mais freqüente é estratificação plano-paralela. Em alguns afloramentos há lâminas cruzadas confinadas em camadas centimétricas tabulares.

Rumo ao topo, repetem-se arenitos laminados dispostos em camadas cuneiformes semelhantes à camada mais basal da unidade.

Estas três camadas representam geralmente os depósitos iniciais da Formação Pirambóia na maioria dos pontos estudados, excetuando-se a região da cidade de Charqueada, onde o topo da Formação Corumbataí esta em contato direto com uma camada com estratificação plano-paralela incipiente.

Ainda na região de Charqueada, em meio aos arenitos da Formação Pirambóia, Chamani et al. (1992) observaram, em duas seções distantes cerca de 10 quilômetros, pelo menos dois níveis de espessura decimétrica a métrica, apresentando estratificações contorcidas, configurando dobras irregulares, de amplitudes centimétrica $e$ decimétrica, sem padrão definido, com camadas freqüentemente rompidas. Tais camadas apresentam grande persistência lateral e encontram-se intercaladas em niveis com estratificações cruzadas de grande porte. A associação destas dobras com outras feições, tais como "falhas em dominó", faihas transcorrentes dextrais com "estruturas-em-flor" negativas, com terminações superiores coincidentes com a base dos níveis perturbados, e injeçōes de areia de forma presumivelmente tabular com estruturas de colapso, fornece, segundo os autores, fortes indícios da ocorrência de fenômenos de liquefação induzidos por abalos sísmicos.

\subsubsection{Paleocorrentes}

\subsubsection{Trabalhos anteriores}

Soares (1973) obteve vetores médios de sentido $W$ nas regiões das rodovias Castelo Branco (SP-280) e Marechal Rondom (SP-270) e de sentido WSW, a norte do rio Piracicaba.

Assine (1993) apresentou para fácies de origem eólica paleocorrentes para SE e SW e fácies de origem fluvial para WSW na "região central do Estado de São Paulo". 
Estes dois exemplos constituem a quase totalidade dos trabalhos conhecidos sobre paleocorrentes da Formação Pirambóia no Estado de São Paulo.

\subsubsection{Resultados obtidos}

O critério de coleta dos dados (item 2.3.2) permitiu um posicionamento estratigráfico mais claro, facilitando a comparação e correlação entre as regiões estudadas. Nos trabalhos citados (Soares 1973 e Assine 1993) não foi usado tal critério. Também trabalhos clássicos sobre paleocorrentes (e.g. Bigarella \& Salamuni 1961) na Formação Botucatu foi detectada tal ausência. Por outro lado, o critério adotado não permitiu uma coleta mais ampla, sendo apresentados apenas 10 pontos relativamente distantes.

Os dados obtidos foram plotados em diagramas circulares em distribuição contínua e em rosáceas (Figuras $8 \mathrm{~A}$ a $8 \mathrm{~J}$ ), segundo o método proposto (Item 2.3.2) e forneceram as informações resumidas na tabela 3.

\begin{tabular}{|c|c|c|c|c|c|c|c|}
\hline PONTOS & $\begin{array}{l}\text { NBMERO } \\
\text { DEE } \\
\text { DABOS }\end{array}$ & $\begin{array}{l}\text { AZMUUTE } \\
\text { OOVETOR } \\
\text { MEDOO }\end{array}$ & $\begin{array}{l}\text { RAZAOODE } \\
\text { CONSIS } \\
\text { TENCIA }\end{array}$ & $\begin{array}{l}\text { DESVIO } \\
\text { PAORAO } \\
\text { ANGULAR }\end{array}$ & ROTACAO & $\begin{array}{l}\text { NTERVALOS } \\
\text { MODASS }\end{array}$ & CHASSHICACAO \\
\hline $\begin{array}{l}1 ; 2 ; 3 ; e \\
4\end{array}$ & 15 & $26,6^{\circ}$ & 25,3 & $70,1^{\circ}$ & $10^{\circ}$ & $\begin{array}{l}{ }^{*}\left(10^{0}-40^{0}\right) \\
\left(310^{0}-340^{\circ}\right)\end{array}$ & $\begin{array}{l}\text { BIMODAL } \\
\text { BIPOLAR AGUDA }\end{array}$ \\
\hline 09 & 12 & $135,7^{\circ}$ & 67,8 & $46,0^{\circ}$ & $20^{\circ}$ & $\begin{array}{l}\left(110^{\circ}-140^{\circ}\right)- \\
\left(170^{\circ}-200^{\circ}\right)\end{array}$ & $\begin{array}{l}\text { BIMODAL } \\
\text { BIPOLAR AGUDA }\end{array}$ \\
\hline 15 & 19 & $206,8^{\circ}$ & 58,0 & $52,5^{\circ}$ & $5^{\circ}$ & $\left(155^{0}-185^{\circ}\right)$ & UNIMODAL \\
\hline 20 & 14 & $226,0^{\circ}$ & 48,9 & $57,9^{\circ}$ & $\begin{array}{c}0^{\circ} \\
\text { (sem rotação) }\end{array}$ & $\begin{array}{l}\left(150^{\circ}-180^{\circ}\right)- \\
\left(240^{\circ}-270^{\circ}\right)\end{array}$ & $\begin{array}{l}\text { BIMODAL } \\
\text { BIPOLAR } \\
\text { ORTOGONAL }\end{array}$ \\
\hline $23 \mathrm{e} 24$ & 15 & $117,4^{\circ}$ & 63,7 & $48,8^{\circ}$ & $10^{\circ}$ & ${ }^{*}\left(100^{\circ}-130^{\circ}\right)$ & UNIMODAL \\
\hline 29 & 10 & $243,4^{\circ}$ & 28,2 & $68,6^{\circ}$ & $5^{0}$ & - & POLIMODAL \\
\hline 38 & 11 & $294,5^{\circ}$ & 34,3 & $65.7^{\circ}$ & $10^{\circ}$ & - & POLIMODAL \\
\hline 41 & 13 & $125,6^{\circ}$ & 51,7 & $56,3^{\circ}$ & $\begin{array}{c}0^{\circ} \\
\text { (sem rotação) }\end{array}$ & $\left(90^{\circ} \cdot 120^{\circ}\right)$ & UNIMODAL \\
\hline 45 & 12 & $118,1^{\circ}$ & 84,4 & $32,0^{\circ}$ & $5^{\circ}$ & $*\left(95^{\circ}-125^{\circ}\right)$ & UNIMODAL \\
\hline 46 & 45 & $353,4^{\circ}$ & 33,1 & $66,3^{\circ}$ & $10^{\circ}$ & - & POLIMODAL \\
\hline
\end{tabular}

* intervalo modal onde se encontra o vetor médio

Tabela 3: Resultados obtidos do tratamento de dados de paleocorrentes da Formação Pirambóia.

Os resultados do tratamento revelaram o predomínio das direções SE e SW nas porções nordeste e central da área estudada, sendo NE e NW predominantes nas porções sul e sudoeste. Estas direções parecem indicar uma área de convergência de paleocorrentes, aproximadamente na porção centro-sul do Estado de São Paulo, 
porém, a pequena quantidade de pontos e a difícil correlação temporal viabilizam apenas tal proposta como preliminar. Por outro lado, as direções seguramente mostram os sentidos das paleocorrentes que iniciaram a deposição da Formação Pirambóia.

A plotagem conjunta dos vetores resultantes de cada ponto, proporcionalmente a sua consistência, mostrou o predomínio geral do sentido SE para as paleocorrentes que atuaram na deposição da porção inicial da base da Formação Pirambóia (Figura 9). 


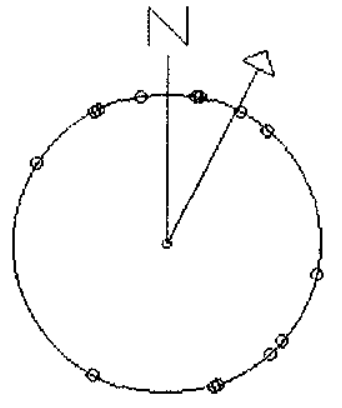

子

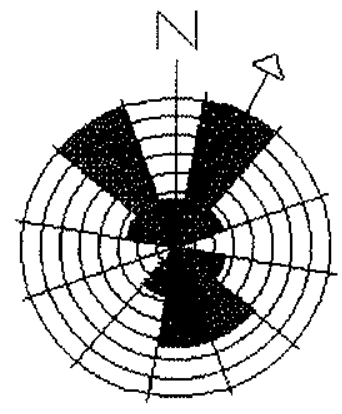

b

Pontos $1,2,3$ e 4

$\mathrm{nd}=15 \quad \mathrm{dpa}=70,1$

$\mathrm{az}=26,6^{\circ}$ rotação $=10^{\circ}$

$\mathrm{RC} \%=25,3$ Bimodal bipolar aguda

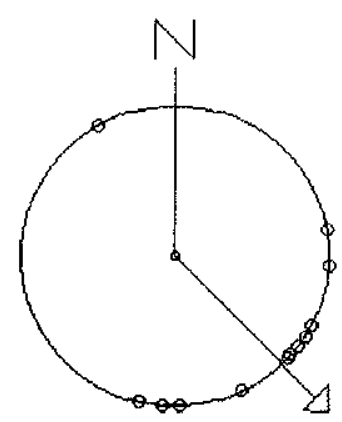

a

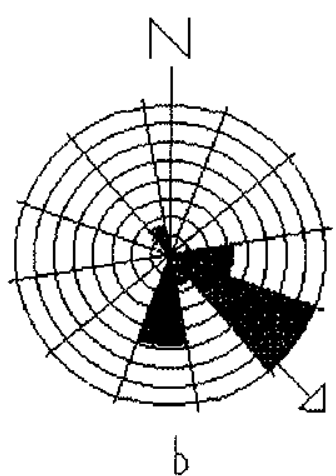

Ponto 9

$\mathrm{nd}=12$

$\mathrm{az}=135,7^{\circ} \quad$ rotação $=20^{\circ}$

$\mathrm{RC} \%=67,8$ Bimodal bipolar aguda

Figura 8 Distribuição das medidas do rumo de mergulho de estratos cruzados da base da Formação Pirambóia (só foram utilizados estratos com mergulho igual ou superior a $5^{\circ}$ ). Para cada ponto estão apresentados: a. diagrama de distribuição contínua com número de dados (nd), resultados do azimute do vetor médio (az), razão de consistência ( $R C \%$ ) e desvio padrão angular (dpa); e b. rosácea com distribuição dos dados em intervalos de $30^{\circ}$, na configuração que apresenta o vetor médio mais próximo do obtido na distribuição contínua (rotação) e sua polaridade. 

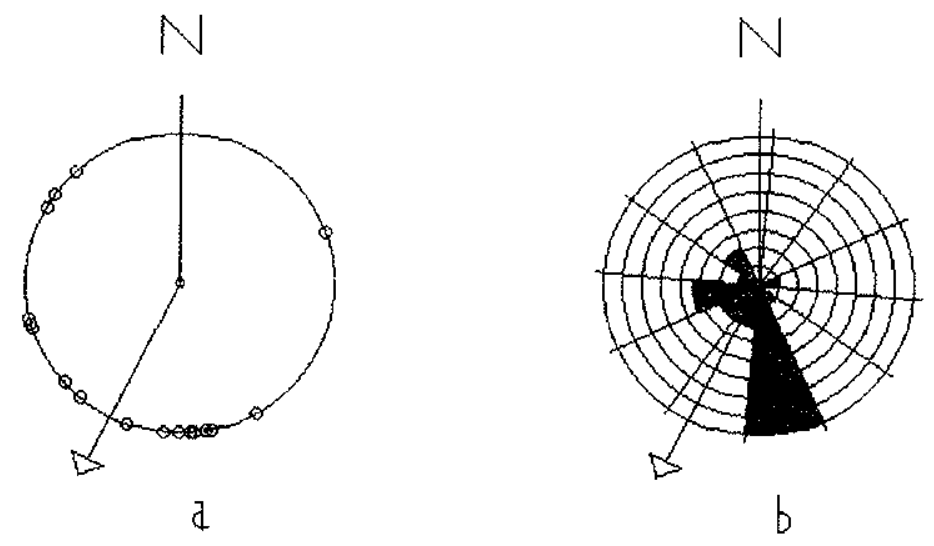

Ponto 15

$\begin{array}{ll}\mathrm{nd}=19 & \text { dpa }=52,5^{\circ} \\ \mathrm{az}=206,8^{\circ} & \text { rotação }=5^{\circ} \\ \mathrm{RC} \%=58,0 & \text { Unimodal }\end{array}$
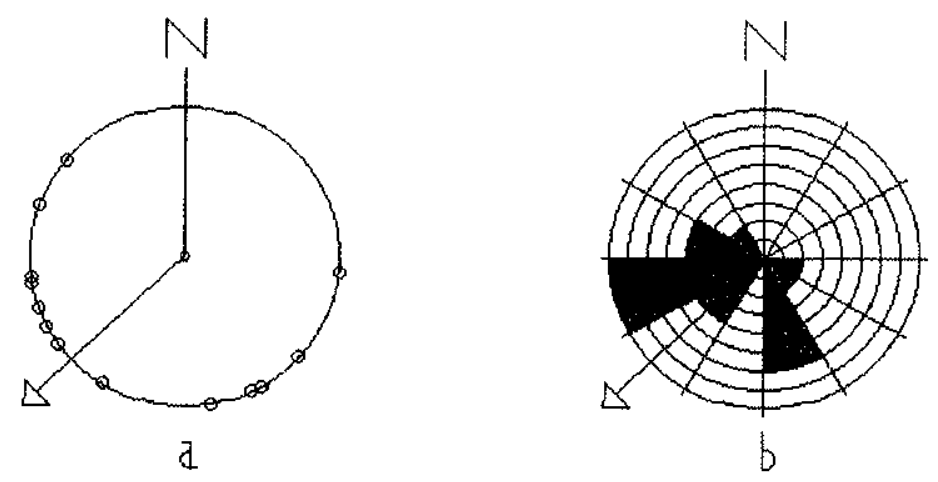

Ponto 20

$\mathrm{nd}=14 \quad \mathrm{dpa}=57,9^{\circ}$

$\mathrm{az}=226,0^{\circ}$ rotação $=0^{\circ}$

$\mathrm{RC} \%=48,9$ Bimodal bipolar ortogonal
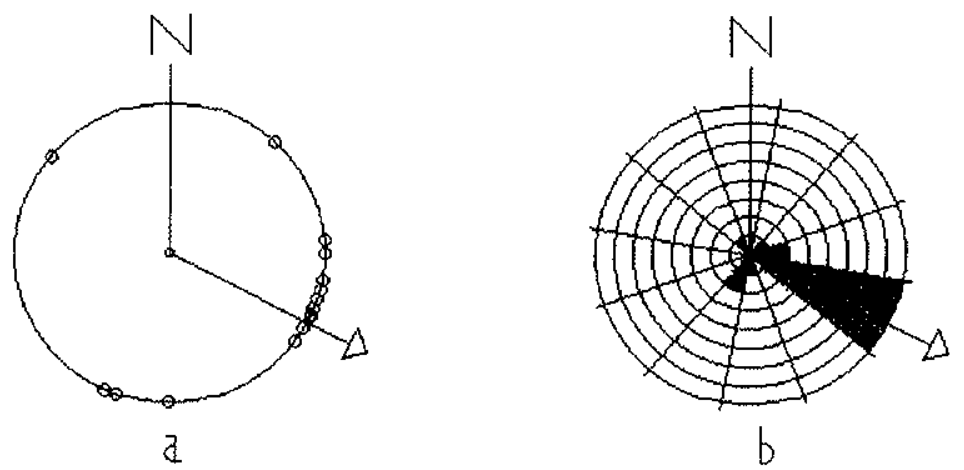

Pontos 23 e 24

$$
\begin{array}{ll}
\mathrm{nd}=15 & \text { dpa }=48,8^{\circ} \\
\mathrm{az}=117,4^{\circ} & \text { rotação }=10^{\circ} \\
\mathrm{RC} \%=63,7 & \text { Unimodal }
\end{array}
$$




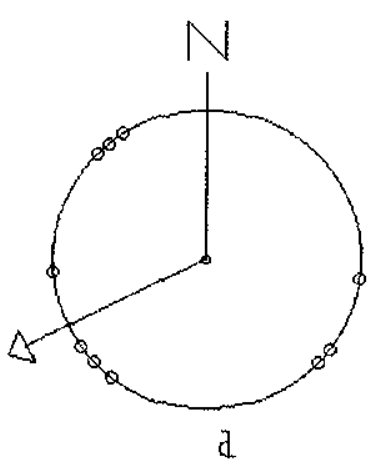

Ponto 29

nd $=10$

$\mathrm{az}=243,4^{\circ}$

$\mathrm{RC} \%=28,2$ $\mathrm{dpa}=68,6^{\circ}$

rotação $=5^{\circ}$

Polimodal
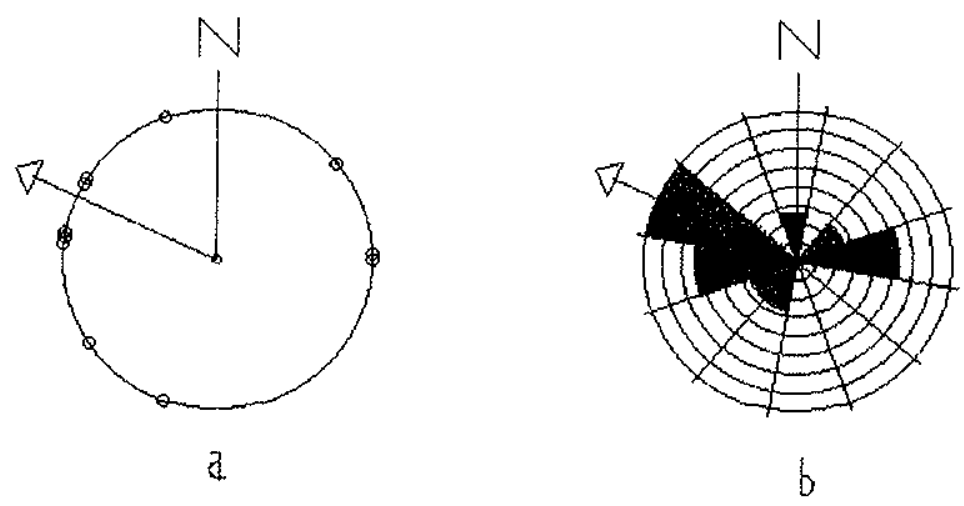

Ponto 38

nd $=11$ $\mathrm{dpa}=65,7^{\circ}$

az $=294,5^{\circ}$

rotaçăo $=10^{\circ}$

RC\% $=34,3$ Polimodal

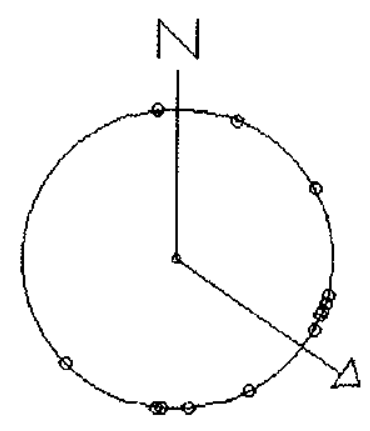

j

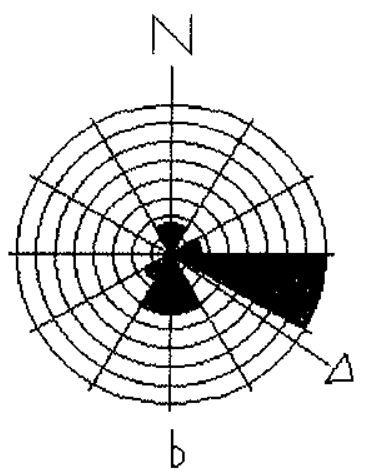

Ponto 41

nd $=13$

$a z=125,6^{\circ}$

$\mathrm{dpa}=56,3^{\circ}$

$\mathrm{RC} \%=51,7$

rotação $=0^{\circ}$

Unimodal

Figura 8: continuaçåo 

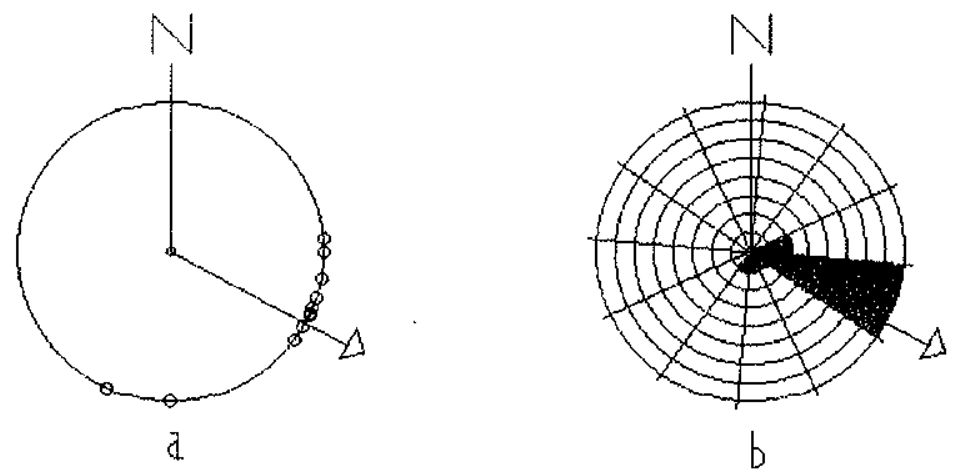

Ponto 45

nd $=12$

$\mathrm{dpa}=32,0^{\circ}$

$a z=118,1^{\circ} \quad$ rotação $=5^{\circ}$

$\mathrm{RC} \%=84,4 \quad$ Unimodal
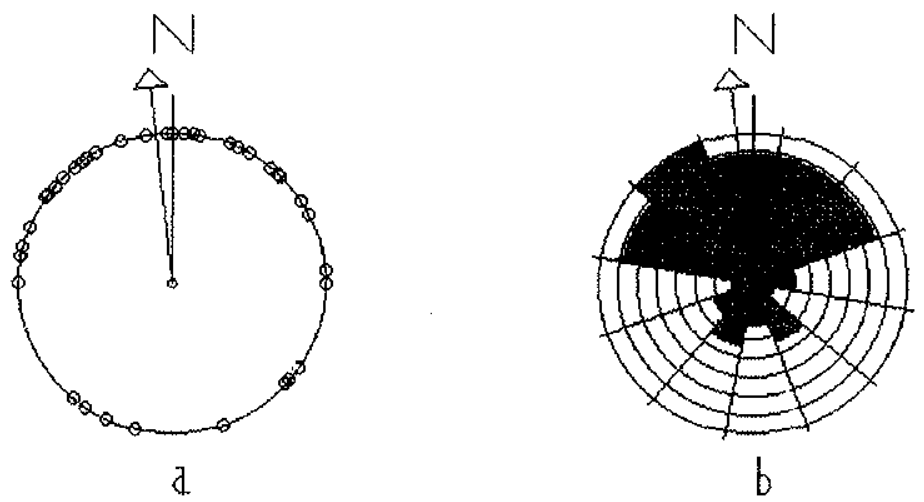

Ponto 46

nd $=45 \quad$ dpa $=66,3^{\circ}$

$a z=353,4^{\circ} \quad$ rotação $=10^{\circ}$

$\mathrm{RC} \%=33,1$ Polimodal 


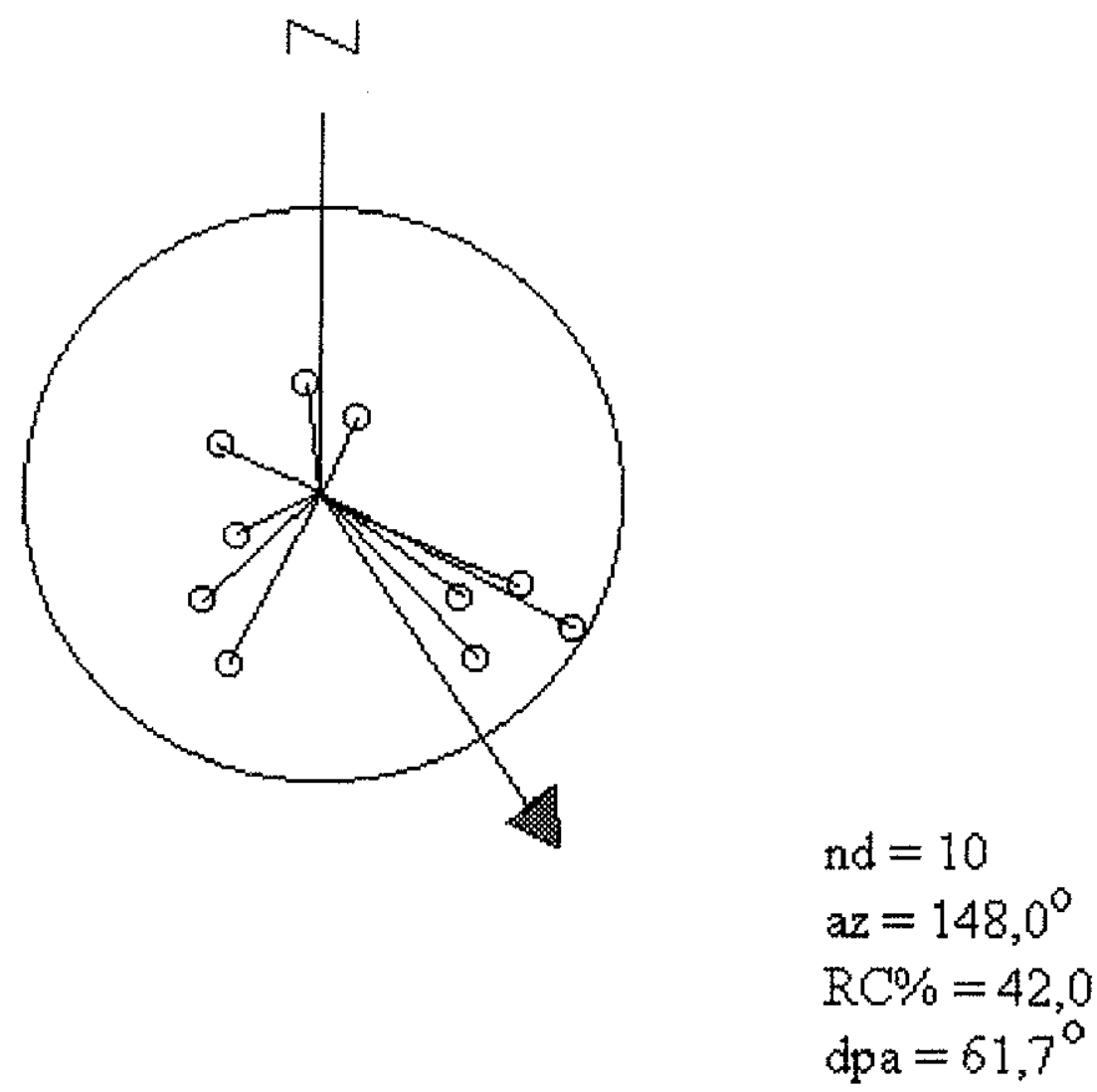

Figura 9: Diagrama da distribuição dos vetores obtidos, proporcionais a suas razões de consistência, com o vetor médio geral (az = azimute do vetor médio geral; $R C \%=$ razão de consistência do vetor médio geral; dpa = desvio padrão angula do vetor médio geral). 


\section{DESCRIÇÃO DAS LITOFÁCIES}

A seguir estão descritas as litofácies reconhecidas no intervalo estratigráfico estudado (Tabela 4).

\subsection{Litofácies LIm}

Caracteriza-se por sedimentos pelíticos, com laminação incipiente ou mesmo maciços, podendo apresentar fósseis dispersos, principalmente conchostráceos. Podem ocorrer cimentações carbonáticas. Gretas de contração são estruturas bastante freqüentes. As cores destes sedimentos variam entre o cinza arroxeado, cinza esverdeado e o rosa.

Esta litofácies constitui camadas tabulares, com espessuras variando entre centimétrica e métrica. Sua ocorrência é generalizada e freqüente nas unidades Teresina Corumbataí e Serrinha. Nas proximidades do contato é mais freqüente nas porções norte (ocorrência da Formação Corumbataí) e na região sudeste (área de ocorrência da Formação Teresina).

\subsection{Litofácies Afl}

Constituí-se principaimente de arenitos finos e muito finos (com grãos menores que $0.25 \mathrm{~mm}$ ), siliciclásticos e laminados.

Apresenta como estruturas sedimentares, estratificações plano-paralelas e cruzadas tangencias na base ou tabulares. Apresentam muitas vezes superfícies de reativação.

Ocorre de forma generalizada, na forma da camadas tabulares métricas a centimétricas, por vezes com superfícies onduladas.

\subsection{Litofácies $\mathrm{Cl}$}

Sedimentos carbonáticos finos, dos tipos micrito e micrito com fósseis (mudstone). Apresentam laminação plano-paralela, por vezes incipiente ou mesmo ausente (maciça). Podem ocorrer fósseis dispersos como conchas de bivalves, carapaças de ostracodes e folhas de licófitas. Constituem camadas tabulares, desde alguns centímetros até alguns metros. 
Algumas das ocorrências de camadas laminadas estão relacionadas à atividade microbiana. Podem apresentar gretamentos e ainda nódulos contornados por lâminas microbianas (Fotos 4 e 5).

A distribuição desta litofácies é generalizada, porém nas proximidades do contato, é mais freqüente nas porções centrais (regiões da Rodovia Castelo Branco, e entre Piracicaba e Anhembi) e sudoeste (regiões de Taguaí e Fartura) do Estado de São Paulo.

\begin{tabular}{|c|c|c|}
\hline LITOFACIES & UNIDADES LITOESTRATIGRAFICAS & PRODUTOS \\
\hline Ap & Base da Formaçáo Pirambóia & $\begin{array}{l}\text { Arenitos constituindo camadas tabulares de espessura } \\
\text { métrica, com seleçăo moderada e com acamamento } \\
\text { plano-paralelo }\end{array}$ \\
\hline$A C$ & Base da Formaçăo Pirambóia & $\begin{array}{l}\text { Arenitos bem selecionados dispostos em camadas } \\
\text { métricas, internamente com estratificacoes cruzadas }\end{array}$ \\
\hline $\mathrm{Am}$ & brechas do contato & Arenito pelitico com estrutura macica \\
\hline $\mathrm{Ai}$ & brechas do contato & $\begin{array}{l}\text { Arenito pelítico com intraclastos ou com poucos } \\
\text { intraclastos angulosos }\end{array}$ \\
\hline Ba & brechas do contato & Brecha com matriz pelitica arenosa \\
\hline BI & brechas do contato & $\begin{array}{l}\text { Brecha com matriz pelfica e poros preenchidos por } \\
\text { calcita }\end{array}$ \\
\hline $\operatorname{LIm}$ & $\begin{array}{l}\text { Topos das formaçбes Teresina, Rio do Rasto e } \\
\text { Corumbataf, e brechas do contato }\end{array}$ & $\begin{array}{l}\text { pelitos e pelitos arenosos, com laminaçâo incipiente a } \\
\text { maciço }\end{array}$ \\
\hline Afl & $\begin{array}{c}\text { Topos das formaçőes Teresina, Rio do Rasto e } \\
\text { Corumbatal }\end{array}$ & $\begin{array}{c}\text { arenitos finos com laminaçáo cruzada, tangenciais na } \\
\text { base, por vezes truncadas }\end{array}$ \\
\hline $\mathrm{Cl}$ & $\begin{array}{l}\text { Topos das formaçסes Teresina, Rio do Rasto e } \\
\text { Corumbatal, e brechas do contato }\end{array}$ & micritos e micritos com fósseis \\
\hline $\mathrm{Ca}$ & $\begin{array}{c}\text { Topos das formaçбes Teresina, Rio do Rasto e } \\
\text { Corumbatal }\end{array}$ & biosparitos e oosparitos \\
\hline$S$ & Formaçăo Teresina & nódulos e camadas de silex \\
\hline
\end{tabular}

Tabela 4: Descrição das fácies reconhecidas e sua relação com os pacotes rochosos.

\subsection{Litofácies $\mathrm{Ca}$}

Sedimentos carbonáticos arenosos compostos por carapaças de ostracodes (biosparitos-packstones) ou por oólitos (oosparitos-grainstones).

Os bioesparitos constituem camadas finas, centimétricas com forma tabulares ou lenticulares (métricas). São mais freqüentes próximo ao contato nas áreas de ocorrência da Formação Teresina

Os oosparitos foram encontrados, próximo do contato, perto da cidade de 
Fartura (estrada de acesso), ainda em sedimentos Teresina. Apresentam marcas onduladas.

\subsection{Litofácies S}

Refere-se as ocorrências de silex, comuns nas proximidades do topo do Grupo Passa Dois, nas formas de lâminas, nódulos ou mesmo camadas, mormente com aspecto maciço.

Os tipos nodulares ocorrem próximos do contato Passa Dois-Pirambóia, dispersos, predominantemente em rochas carbonáticas (como nos microbialitos) ou podem estar agrupados em camadas, como as encontradas nos quilômetros 165 e 168 (neste ocorrem duas camadas separadas po $80 \mathrm{~cm}$ de sedimentos) da rodovia Castelo Branco (pontos 7 e 18), as quais têm $5 \mathrm{~cm}$ a $6 \mathrm{~cm}$ de espessura, com forma tabular e contínua e constituí-se de "grânulos" e "seixos" de silex maciço, com excelente "arredondamento", formas esféricas e elipsoidais, ocorrendo raros contatos entre os os nódulos, estando os poros preenchidos por cimentos carbonático (franjas) e silex fibrorradiado (Fotos 6 a 10). Tal textura recebeu o nome de pé-de-moleque.

As ocorrência de Anhembi, encontram-se num contexto diferente, por isso foram tratadas separadamente no item 7.5 .

\subsection{Litofácies BI}

Caracteriza-se por brechas compostas de intraclastos de composição variável, predominando as carbonáticas (cinza amareladas) seguindo-se as de pelitos (amareladas) e de sílex (cinzas). Tais fragmentos apresentam formas angulosas, tabulares ou irregulares, decimétricos a milimétricos, imersos em matriz pelítica (predominantemente argilosa), com eventuais poros preenchidos por cimento carbonático.

O arranjo dos intraclastos dentro das camadas de brechas geralmente não obedece um padrão definível, sendo predominantemente caótico. Localmente, porém, podem ser observadas porções com discreta tendência a orientação do tipo paralela, horizontal ou pouco inclinada.

As camadas de brechas apresentam forma tabular na escala de afloramento. São freqüentes sobre os topos das unidades Teresina, Corumbataí e Serrinha, no Estado de São Paulo, atingindo espessuras entre $10 \mathrm{~cm}$ e alguns metros $(2,0 \mathrm{~m}$ em afloramentos e 3,2 $\mathrm{m}$ em subsuperfície). Também podem ocorrer em porções médias da Formação Teresina, com pequenas espessuras e isoladas como reconhecidas por Fúlfaro (1970)

Ao longo da faixa estudada ocorrem variações quanto a freqüência e 
dimensão. Ela é mais freqüente, ou seja, intercala-se mais com outras fácies em afloramentos situados relativamente mais a leste e a sul. Suas espessuras tendem a diminuir no sentido oeste.

Quanto a cor, é avermelhada quando fresca, apresentando-se roxa ou amarela em porções alteradas.

\subsection{Litofácies $\mathrm{Ba}$}

Brecha com intraclastos (mais de $25 \%$ ), com formas angulosas tabulares ou irregulares, compostos de carbonatos (alterados muitas vezes), pelitos e sílex friável. Estão imersos em matriz pelítica arenosa fina, avermelhada. Os intraclastos podem ter arranjo caótico ou orientado na forma paralela horizontal ou com inclinação suave.

A camada de brecha é tabular e apresenta gradação normal aparente (granodecrescência ascendente).

Sua ocorrência está relacionada ao contato Passa Dois-Pirambóia.

\subsection{Litofácies $\mathrm{Ai}$}

Arenito fino pelítico com intraclastos (entre 10\% e 25\%), passando gradativamente para arenito fino pelítico com pouco intraclastos. Os intraclastos podem ser carbonáticos (alterados) ou pelíticos. As formas dos intraclastos são irregulares ou tabulares, com dimensões entre alguns milímetros até $2 \mathrm{~cm}$.

As camadas são tabulares e estão relacionadas ao contato Passa DoisPirambóia.

\subsection{Litofácies Am}

Caracteriza-se por arenito fino, pelítico, livre de intraclastos ou qualquer outro fragmento maior que areia. Não apresenta estruturas internas, sendo considerado maciço. Apresenta-se na forma de camada tabular, com espessuras entre $10 \mathrm{~cm}$ e 30 $\mathrm{cm}$.

Sua ocorrência também esta relacionada ao contato Passa Dois-Pirambóia.

\subsection{Facies Ac}

Lâminas e lentes de arenito fino siliciclástico, bem selecionado, intercalados com lâminas de arenito fino siliciclástico, moderadamente selecionado.

Constituem conjuntos de laminas cruzadas (sets) que variam entre $2 \mathrm{~m}$ e $6 \mathrm{~m}$ de extensão e de $10 \mathrm{~cm}$ a $3 \mathrm{~m}$ de altura, com mergulhos entre $5^{\circ}$ e $25^{\circ}$, geralmente 
tangenciais na base e truncadas no topo. Estes conjuntos estão agrupados em camadas tabulares de 2 a $5 \mathrm{~m}$ de espessura.

Estas camadas ocorrem de forma generalizada na base Formação Pirambóia

\subsection{Litofácies Ap}

Arenitos finos e médios, com pouca matriz pelítica. Apresenta-se na forma de camadas tabulares com espessura de alguns metros, internamente laminadas na forma plano-paralela, por vezes incipiente, podendo ainda ocorrer lâminas de arenitos cruzadas confinadas a camadas centimétricas. É freqüente na base da Formação Pirambóia. 


\section{RELAÇÕES ENTRE AS LITOFÁCIES - SUCESSÕES}

As litofácies anteriormente descritas foram divididas em três conjuntos de ocorrencia: (1) intervalo correspondente ao topo das unidades Teresina, Corumbataí e Rio do Rasto; (2) brechas do contato; e (3) intervalo correspondente à base da Formaçăo Pirambóia. Tal divisão baseou-se na freqüência, abundância e ainda na exclusividade de ocorrência das litofácies.

6.1. Intervalo correspondente ao topo das unidades Teresina, Corumbataí e Rio do Rasto

As litofácies características deste intervalo são: $\mathrm{LIm}, \mathrm{Cl}, \mathrm{Afl}, \mathrm{Ca}, \mathrm{Bl}$ e S.

A litofácies LIm é uma das fácies predominantes neste intervalo. Pode estar representada por sedimentos ora mais argilosos, ora mais siltosos, intercalados verticalmente. Estas variações revelam variações relativamente pequenas nas condições deposicionais. O contato entre cada camada pode ser gradacional ou abrupto (sharp). A litofácies Afl, de menor expressão, aparece intercalada em depósitos pelíticos (litofácies LIm), na forma de camadas centimétricas a decimétricas, mantendo contatos abruptos com estes. Esta intercalação pode dar-se também entre finas camadas e/ou lâminas, com sedimentos pelíticos recobrindo ondulações dos depósitos areníticos, formando acamamentos dos tipos flaser, lenticular ou wavy. A presença de estratificações cruzadas indica a atuação de correntes direcionais físicas trativa (tração ou tração e suspensão) ou oscilatória.

A litofácies $\mathrm{Cl}$ é outra fácies freqüente neste intervalo. Ela está representada principalmente por micritos e micritos com fosseis (mudstones), sendo o principal processo de deposição a precipitação de material em suspensão. A presença de elementos fósseis como carapaças (ostracodes), conchas (bivalves) ou ainda possíveis "folhas fósseis (licófitas)", nenhum destes em posição de vida, foi interpretada como proveniente de transporte. Estes elementos fósseis também podem estar acumulados em grandes quantidades, constituindo depósitos biomicríticos (packstones e grainstones), descritos como litofácies $\mathrm{Ca}$. Laminações microbianas, também incluídas na litofácies $\mathrm{Cl}$, geradas pelo aprisionamento de partículas ou pela precipitação química de material dissolvido na água regidos pelos filamentos de organismos microscópicos dispostos em extensas esteiras, intercalam-se com depósitos de micritos. As relações de contato entre corpos da litofácies $\mathrm{Cl}$ podem ser abruptos, por vezes marcados por gretamentos, ou gradacionais, passando-se de porções com fósseis para porções livres destes.

$\mathrm{Na}$ litofácies $\mathrm{Cl}$, além dos depósitos de carapaças, também estão incluidos os 
depósitos oolíticos. Esta litofácies foi gerada pela atuação de procesos físicos trativos (tração e tração mais suspensão). Semelhantemente as litofácies Afl e LIm, a litofácies $\mathrm{Ca}$, intercalada com a litofácies $\mathrm{Cl}$ podem formar acamamentos dos tipos flaser, lenticular ou wavy. As relações de contato com a litofácies $\mathrm{Cl}$ são geralmente abruptas.

A litofácies $\mathrm{BI}$ tem pequena expressão tanto em freqüência como em espessura neste intervalo, estando intercalada geralmente em sedimentos da litofácies $\mathrm{Cl}$. Origina-se do acúmulo de intraclastos em eventos de alta dissipação de energia e alta capacidade de transporte; da superposição de várias fases de gretamento marcando períodos de exposição subaérea, com preenchimento posterior de poros por material sedimentar; ou ainda pelo rompimento de camadas por crescimento de cristais.

Os silexítos da litofácies $\mathrm{S}$ ocorrem nas formas de finas camadas ou ainda na forma de nódulos envolvidos por lâminas deformadas. Tem origem mormente pósdeposicional (em relação ao sedimento no qual ocorre) por pricipitação química, substituindo porções ou preenchendo poros do hopedeiro. No caso das camadas compostas por nódulos, os pés-de-moleque, há contato aparentemante transicional com a camada inferior, calcilutítica (litofácies $\mathrm{Cl}$ ) e abrupta com a camada superior.

As litofácies carbonáticas ( $\mathrm{Cl}$ e $\mathrm{Ca}$ ) e as litofácies siliciclásticas ( $\mathrm{Llm}$ e Afl) também aparecem intercaladas neste intervalo. Os contatos entre os dois tipos de litofácies são abruptos. É reconhecido que a presença excessiva de siliciclásticos tende a inibir a formação e deposição de sedimentos carbonáticos (Selley 1985, Miall 1992, Jones \& Desrochers 1992). Esta condição indica que ocorrem nos depósitos deste intervalo sucessões carbonáticas e siliciclásticas intercaladas e geradas em condições ambientais diferentes.

\subsection{Brechas do contato}

Neste conjunto foi reconhecida uma sucessão de fácies que repete-se ao longo de quase toda faixa de afloramentos, sempre na mesma posição estratigráfica: contato Passa Dois-Pirambóia.

É constituída pela intercalação de camadas de brechas (litofácies $\mathrm{BI}$ ) com camadas interbrechas de micritos ou micritos com fósseis (litofácies $\mathrm{Cl}$ ) ou ainda com camadas de pelitos (litofácies LIm). Os contatos podem ser abruptos entre camadas de brechas e camadas interbrechas, transicionais entre os topos de camadas interbrechas e bases de camadas de brechas (Prancha 5 - Fotos 21) e abruptos entre camadas de brecha. Rumo ao topo, a última camada de brecha com matriz pelítica (litofácies $\mathrm{BI}$ ) é seguida de uma sucessão composta de brecha com matriz pelítica arenosa (litofácies $\mathrm{Ba}$ ), arenitos com intraclastos (litofácies $\mathrm{Ai}$ ) e arenito pelítico 
maciço (litofácies Am), a qual aparenta ser uma gradação textural. Esta sucessão de fácies será referida como sucessão A (Figura 10).

Foram descritas seções deste intervalo e somadas as existente de perfutrações da PETROBRÁS (Roncarati 1971) para a montagem de perfis que permitiram uma análise das variações e da distribuiçao das brechas do contato.

Nos perfis E-W foi reconhecida uma tendência de acunheamento, com diminuição na espessura da sucessão $A$ no rumo oeste (Figura 11 - perfis A-A'; B-B'; C-C'; D-D'). A espessura média da sucessão em superfície é de $1,80 \mathrm{~m}$, variando entre $0,50 \mathrm{~m}$ e 2,50 $\mathrm{m}$. Em subsuperfície pode apresentar espessuras mais expressivas
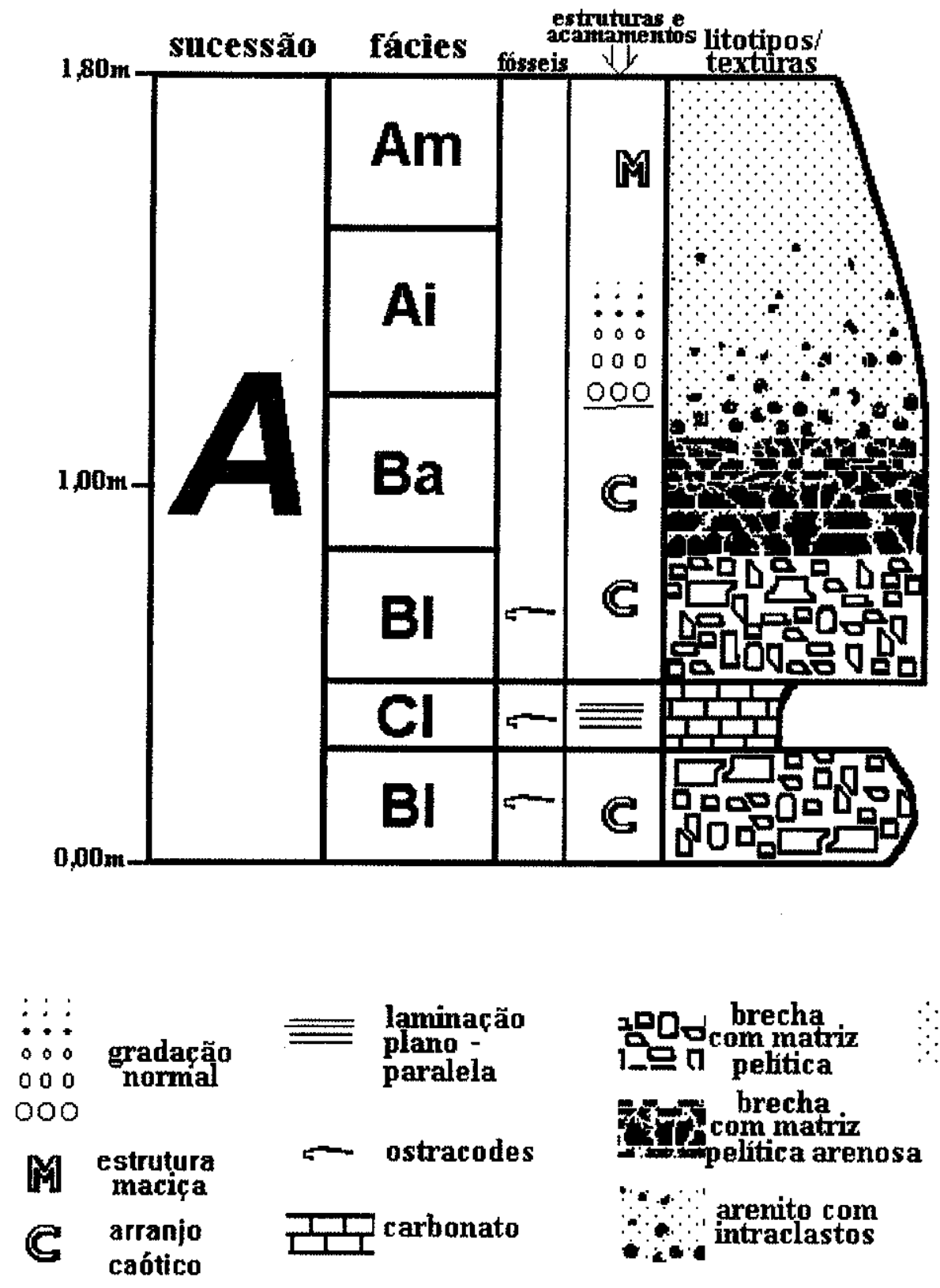

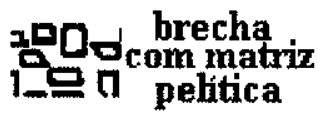

arenito pelítico

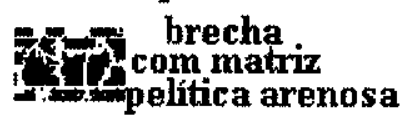

$\therefore$ intraclastos

Figura 10: espessuras das camadas correspondem somente as médias dos afloramentos 
variando entre $0,5 \mathrm{~m}$ e 4,25 $\mathrm{m}$ (2,00 $\mathrm{m}$ em média). A distribuição em área das brechas do contato é de difícil determinação devido ao caráter pontual das observações, principalmente em afloramentos, com informações de subsuperfície muito localizadas. Porém, alguns parâmetro relativos às suas dimensões puderam ser avaliados. No caso do perfil A-A' (Figura 11), se a sucessão for considerada um corpo contínuo horizontalmente, que afina para oeste, pode-se inferir uma seção de aproximadamente $27 \mathrm{~km}$ de extensão, assim também nos perfis: B-B', C-C' e D-D',com $8 \mathrm{~km}, 12 \mathrm{~km}$ e $18 \mathrm{~km}$ de extensão respectivamente.

A presença de brechas compostas por intraclastos (litofácies $\mathrm{Bl}$ e $\mathrm{Ba}$ ) foi atribuída principalmente a processos de variação de volume, provocados por constante exposição de sedimentos.

A maioria dos trabalhos anteriores considerou a gênese desta porção das brechas do contato como exclusivamente gerada por correntes aquosas, as quais teriam transportado e depositado os clastos, (e.g. Barbosa \& Gomes 1958, Landim 1970, Fúlfaro 1970). Também foram sugeridos processos de escorregamento ou derrocada (e.g. Washburne 1930, Almeida \& Barbosa 1953, Soares 1973), ou ainda algo semelhante a um colúvio formado sem a ação de correntes aquosas (Almeida 1954, 1964).

Constatou-se, entretanto, a ausência da atuação de processos dinâmicos através das seguintes características observadas nos depósitos de brechas: freqüente arranjo do tipo mosaico na superfície das camadas de brecha; a não homogeneidade das camadas de brechas, sendo possivel encontrar, em um único estrato, brechas intercaladas horizontalmente com porções apenas fraturadas da camada original; o arranjo caótico predominante com pequenas porções levemente orientadas; a presença de granocrescência e granodecrescência em uma mesma camada.

A inexistência de evidências de gradientes acentuados, apreciáveis em áreas relativamente exíguas, descartou a possibilidade de atuação de fluxos gravitacionais de massa na geração das brechas.

Processos dinâmicos de longa duração (Lasnicka 1988) como: pressurização e despressurização de fluídos, diapirismo, deformação de camadas por movimentos tectônicos, também puderam ser descartados, pois tenderiam a desfazer a integridade (limites e continuidade) das camadas, o que não foi observado.

Dois tipos de processos foram então consideradas como mais prováveis e predominantes: (1) variação de volume, que pode ser causado por contração por dessecação (desidratação), por expansão e contração combinadas (comum a regiões áridas) e por expansão (hidratação de sais); (2) processos químicos e físicos-químicos como os de dissolução e corrosão (que pode resultar em colapsos), de dissolução por pressão (estilólitos), crescimento de cristais, cimentação e recristalização. 


\begin{tabular}{|l|l|l|}
\hline & Ap & $\begin{array}{l}\text { Arenitos constituindo camadas tabulares, com seleção moderada e com } \\
\text { estratificações plano-paralela. }\end{array}$ \\
\hline & Ac & Arenitos bem selecionados dispostos em sets de estratificações cruzadas \\
\hline & Am & Arenito pelítico com estrutura maciça \\
\hline & Ai & Arenito pelítico com intraclastos ou com poucos intraclastos \\
\hline & Ba & Brechas com matriz pelítica arenosa \\
\hline & BI & Brechas com matriz pelitica \\
\hline & Ca & Bioesparitos e oosparitos \\
\hline & & \\
\hline
\end{tabular}

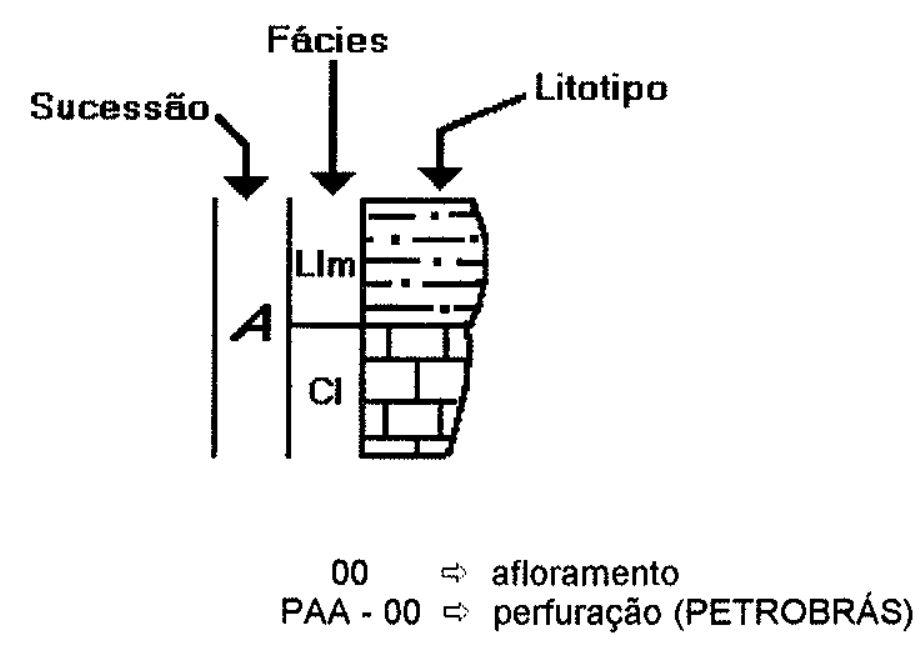

Figura 11: Legenda para as seções das brechas do contato nos perfis: A-A'; B-B'; C-C'; D-D'; E-E'; F-F'; G-G' . 


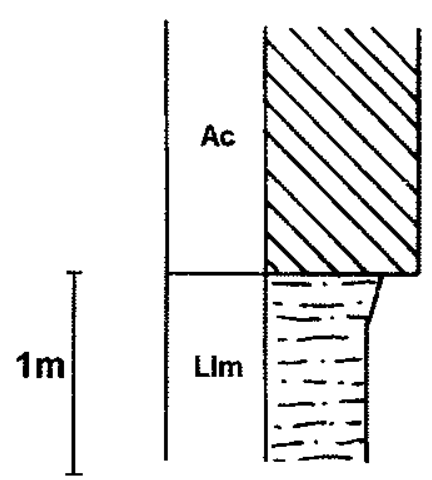

PAA - 11

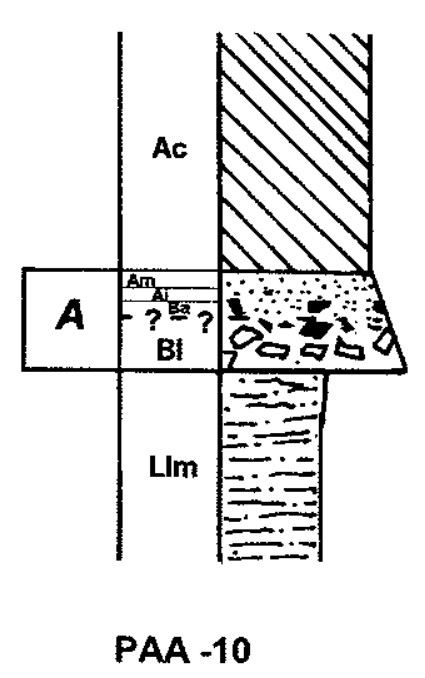

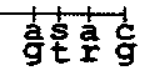

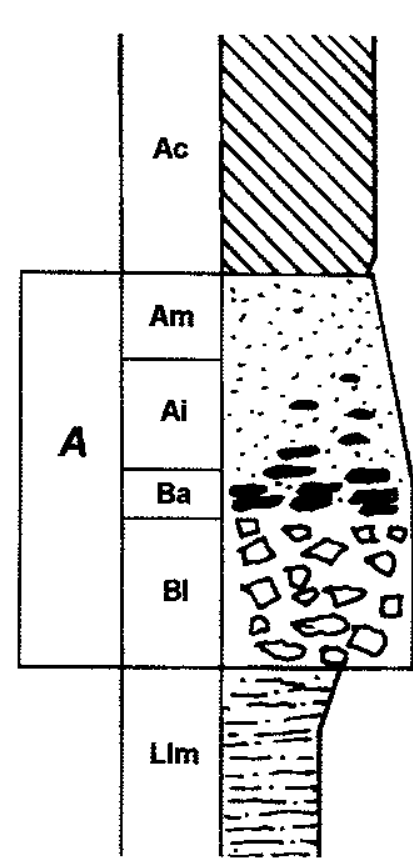

58

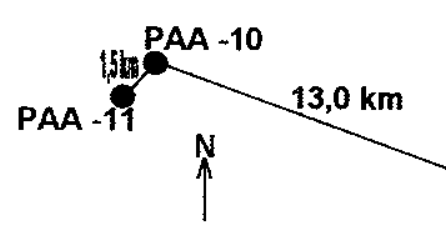

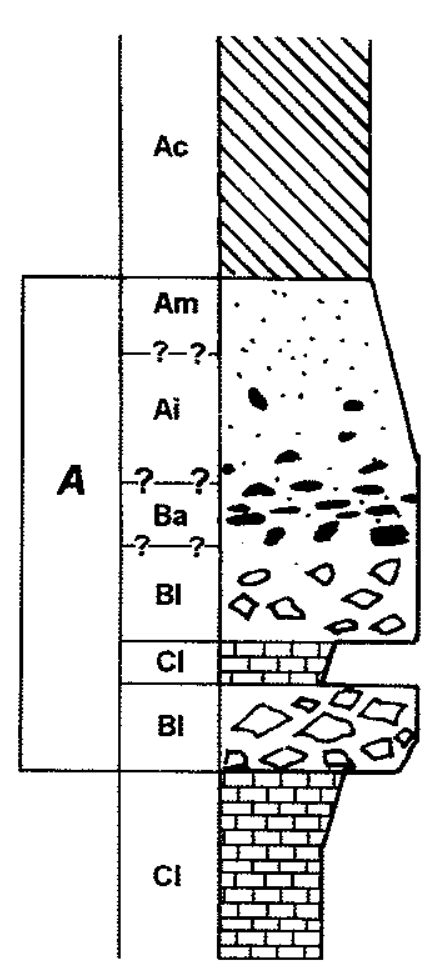

PAA -13

A 
Ш
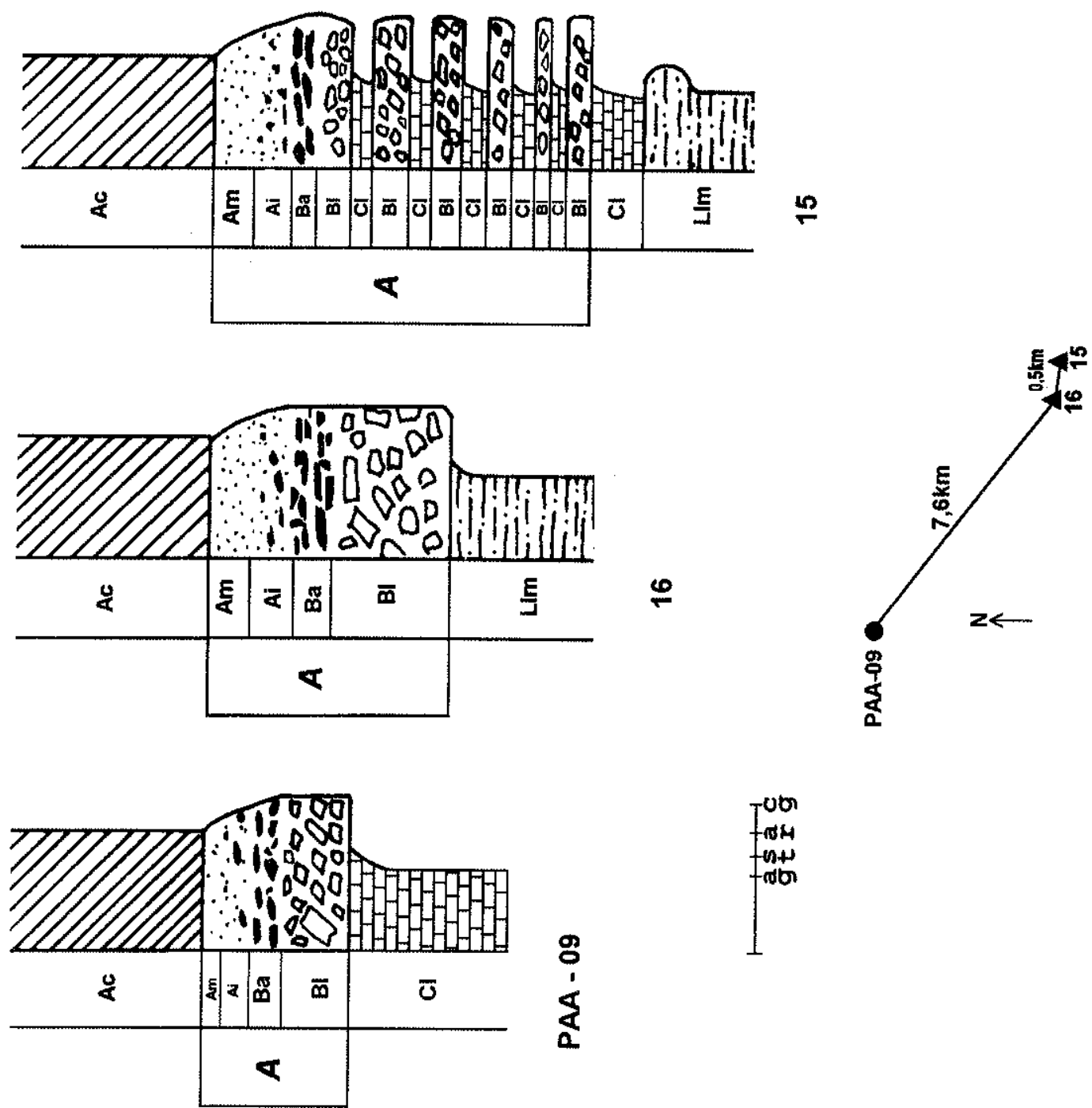

3

$\frac{1}{4}$ 


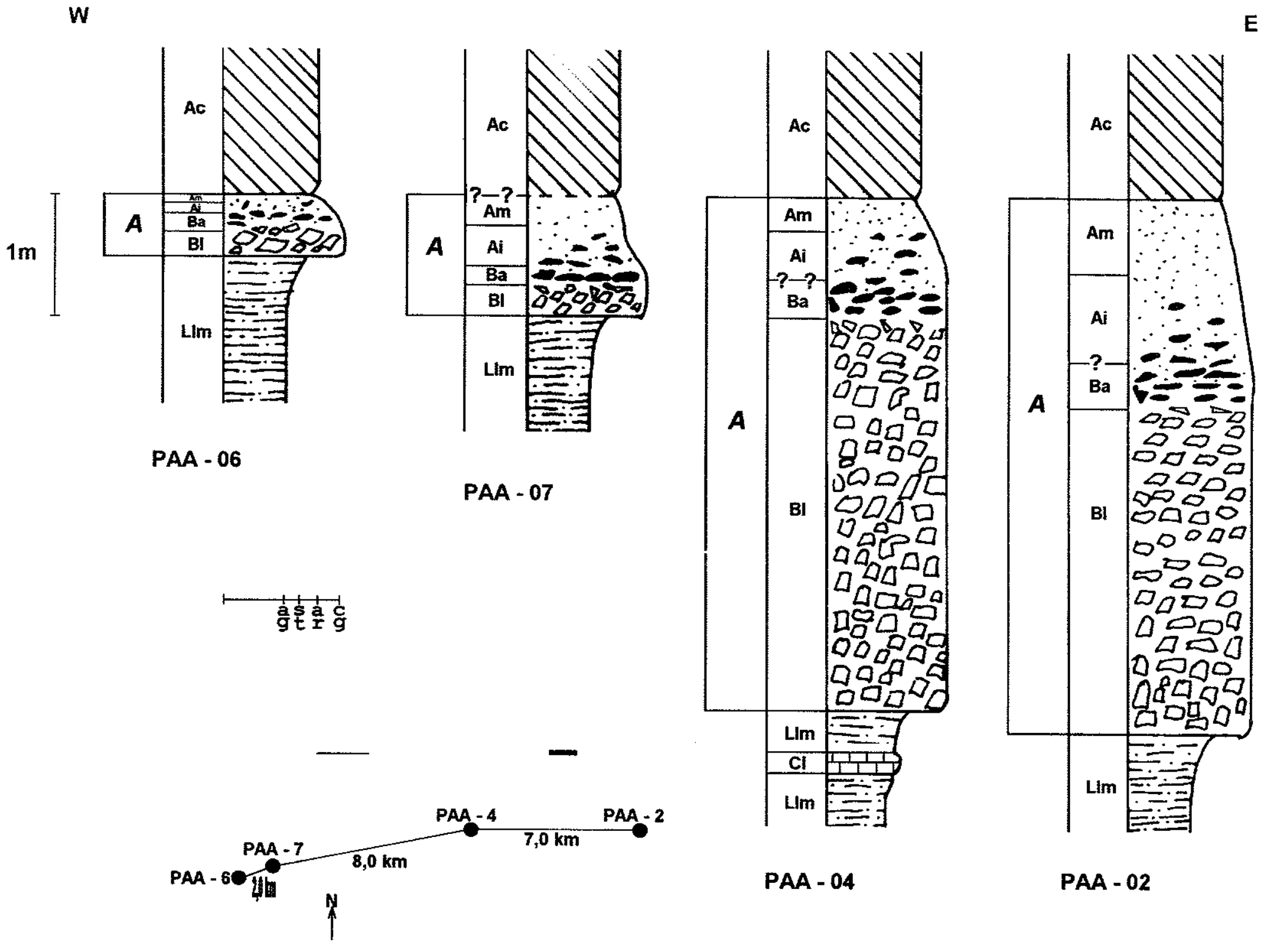


w

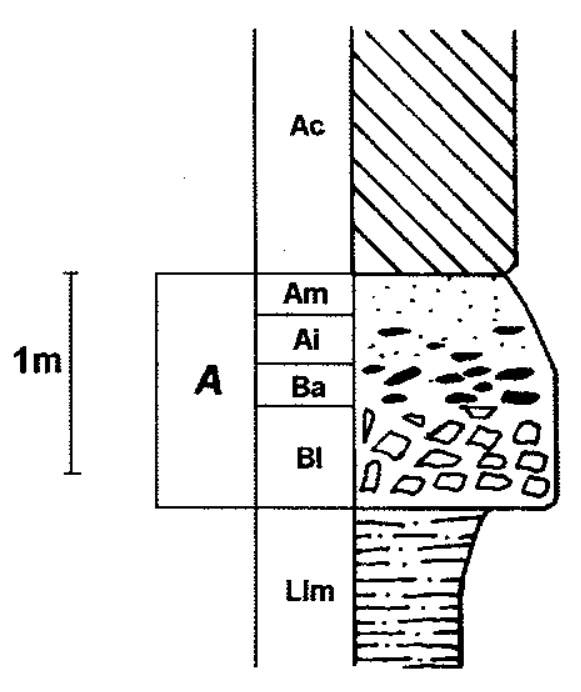

PAA - 08

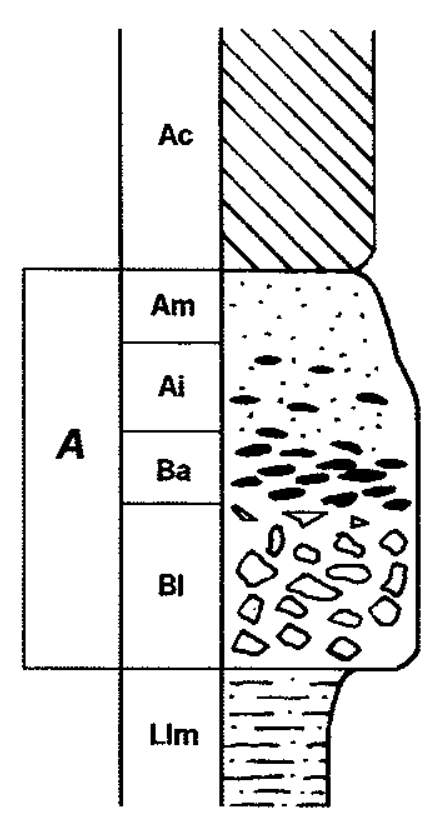

PAA - 05

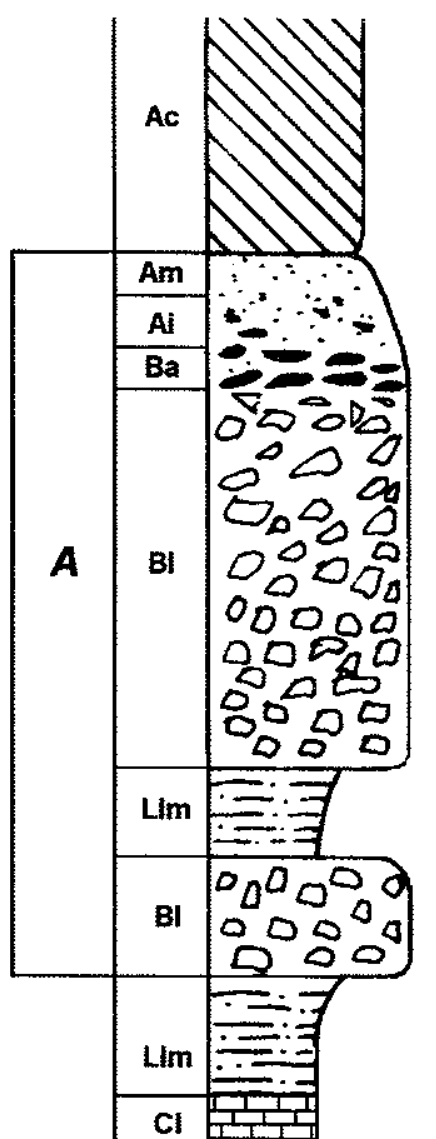

PAA - 03

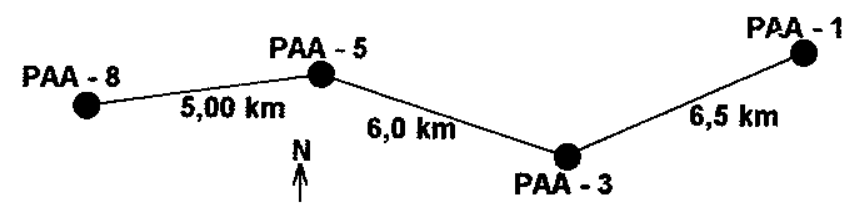

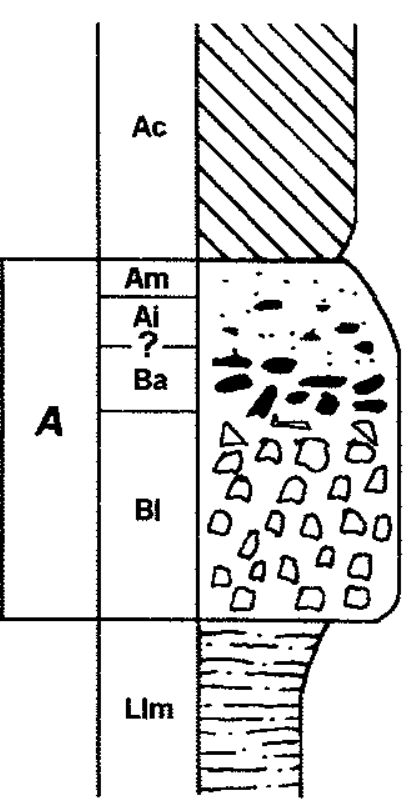

PAA - 01

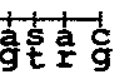

D 
w
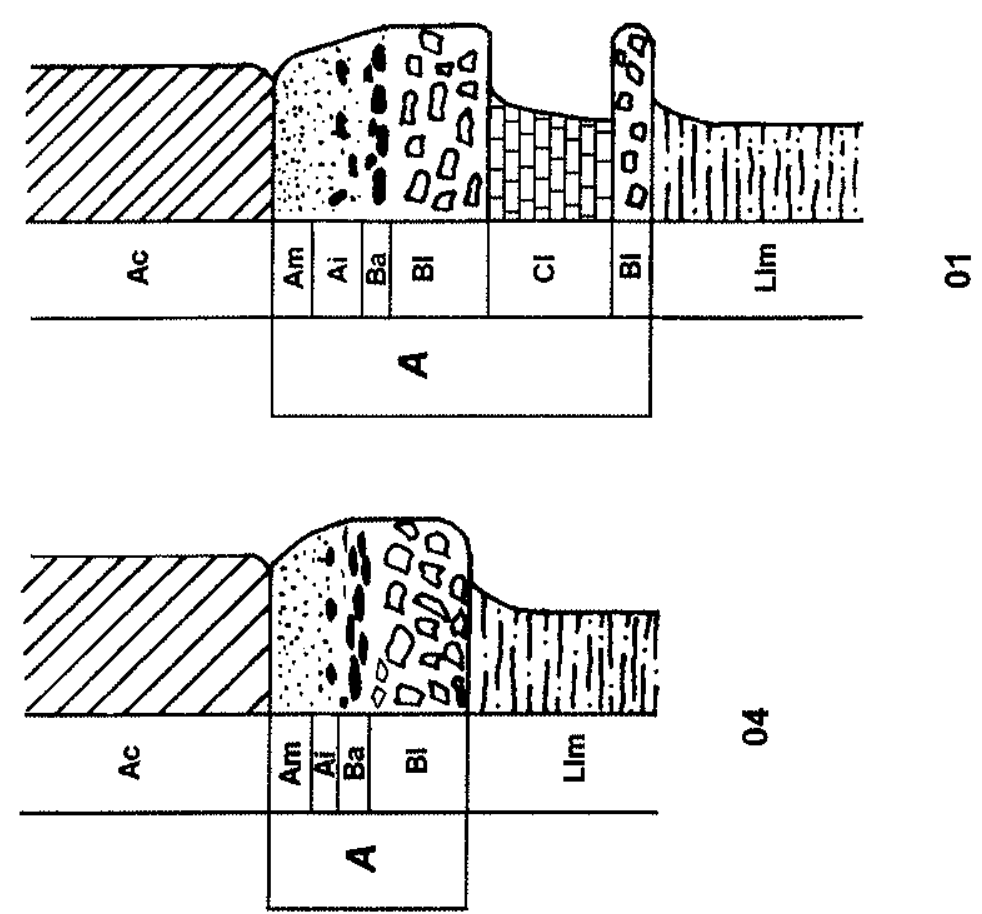

I
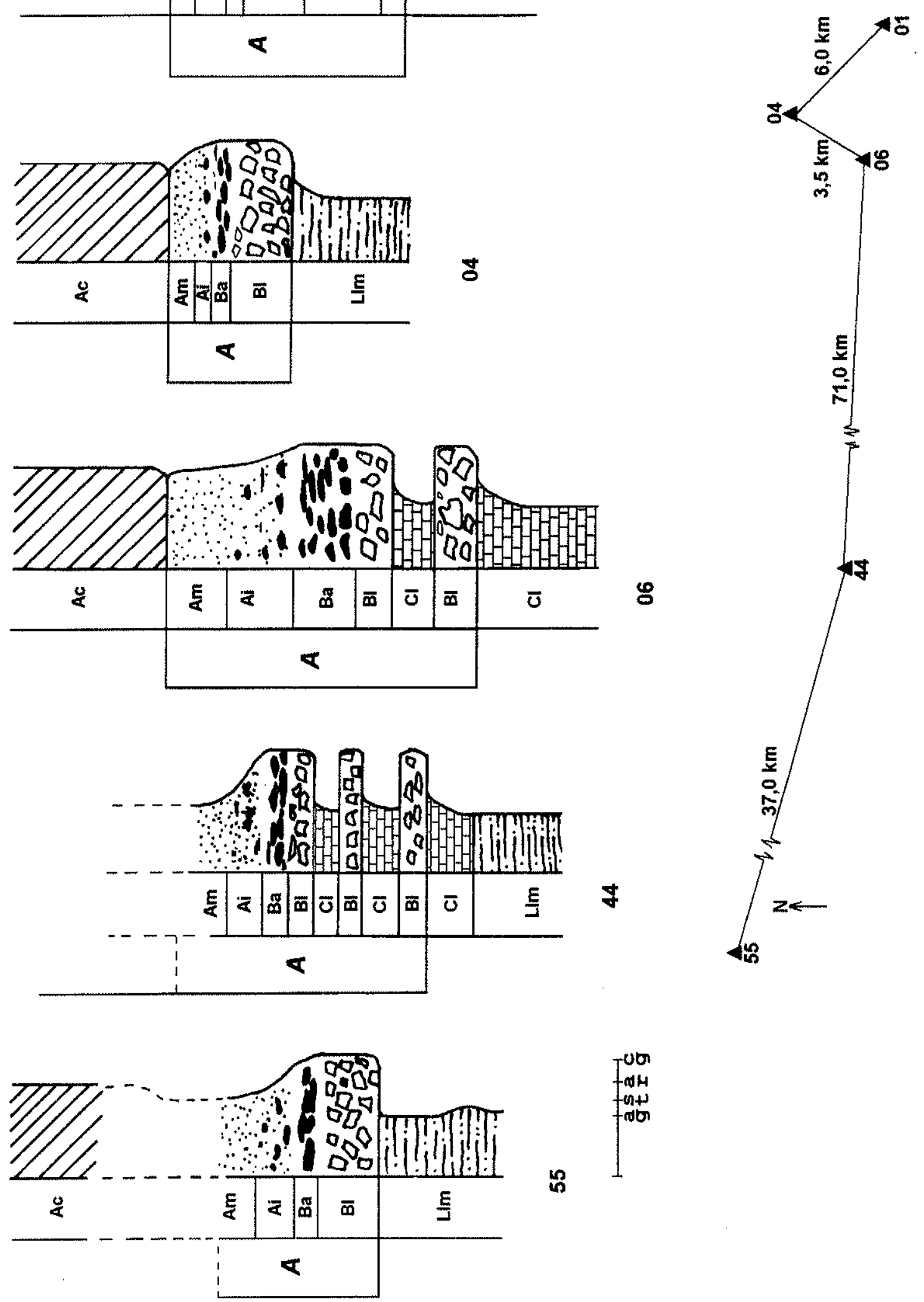


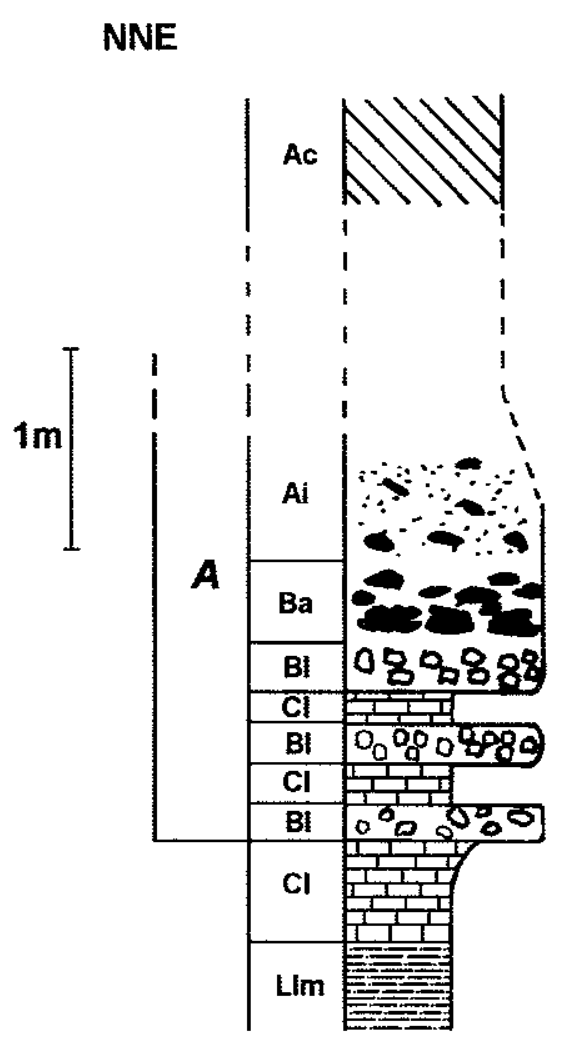

10
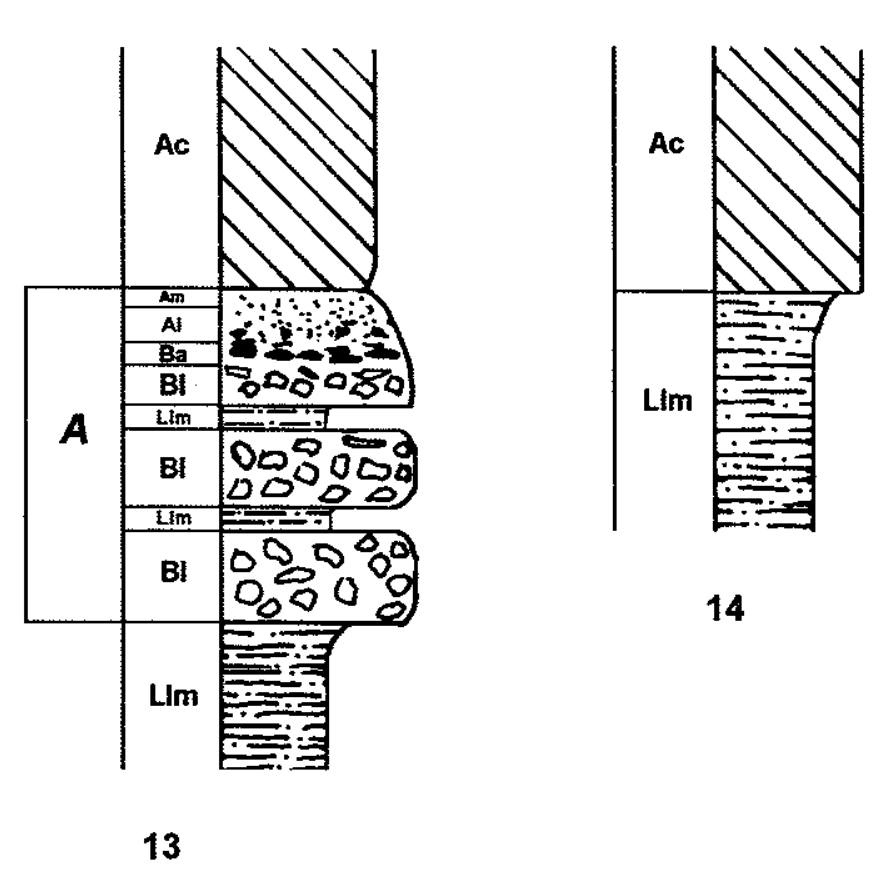

14

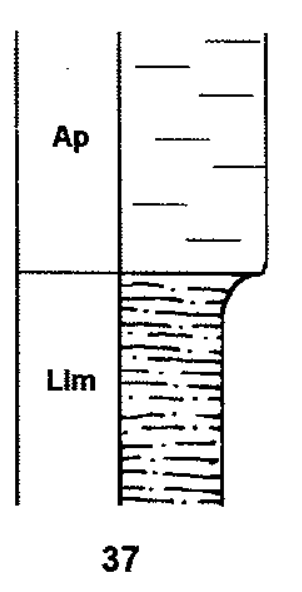

$$
\underset{20}{11,0 \mathrm{~km}} \underset{37}{14} \frac{14,0 \mathrm{~km}}{14} \underbrace{3,0 \mathrm{~mm}}_{13} 11,0 \mathrm{~km}
$$

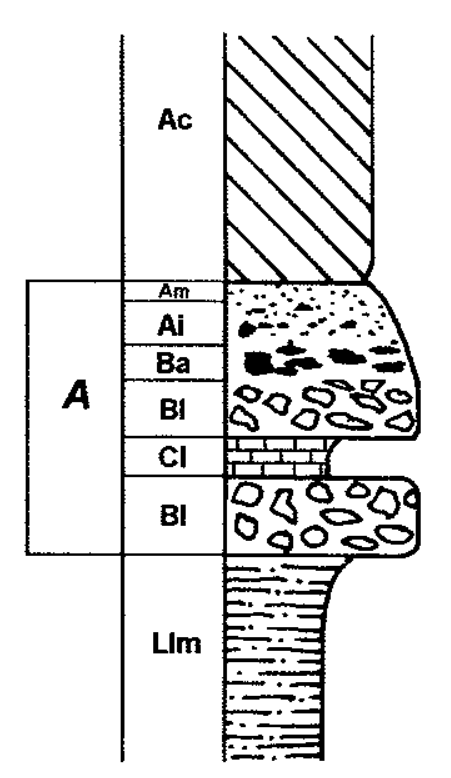

20

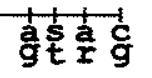




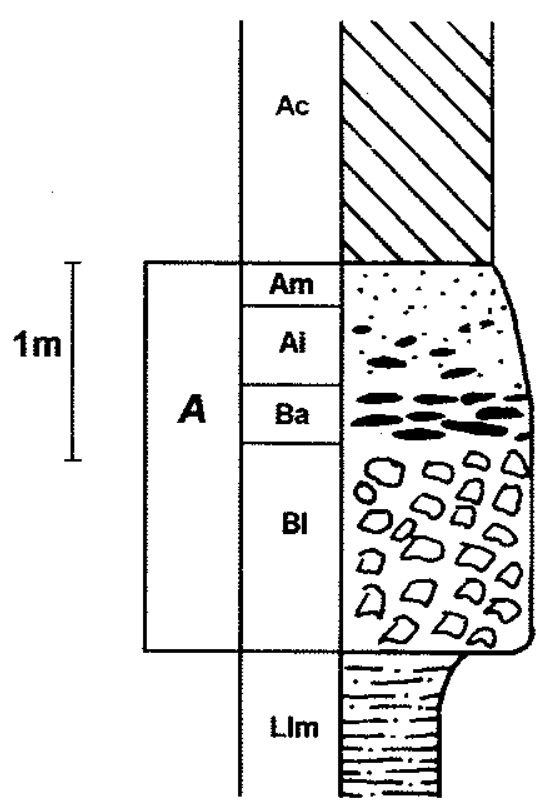

23
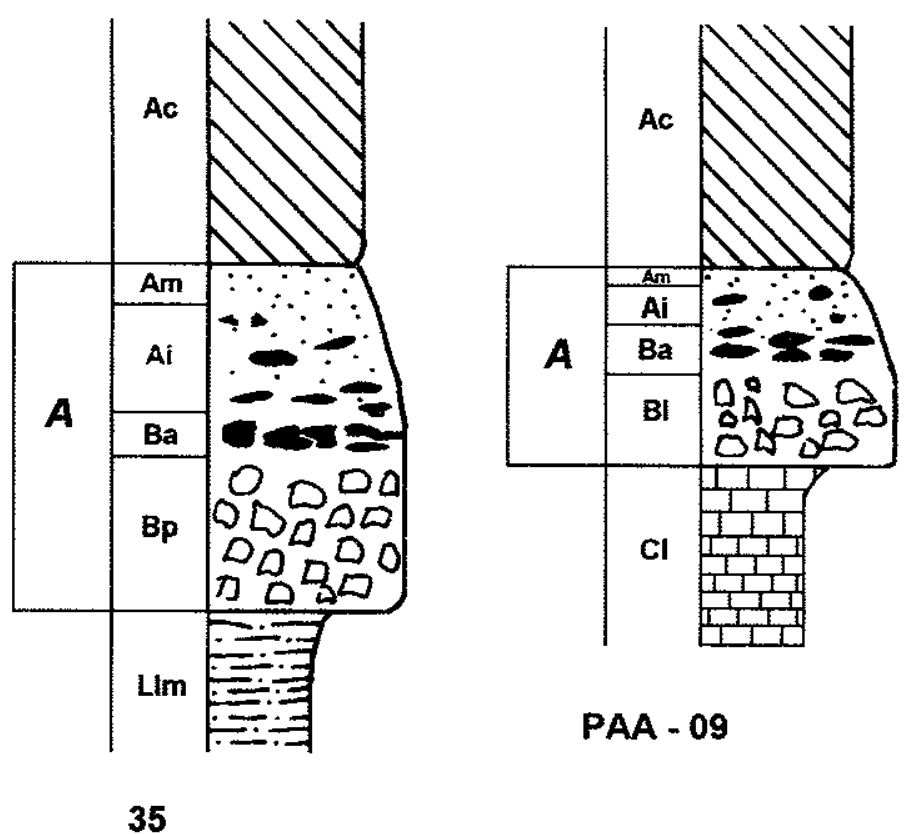

PAA - 09

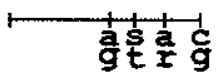

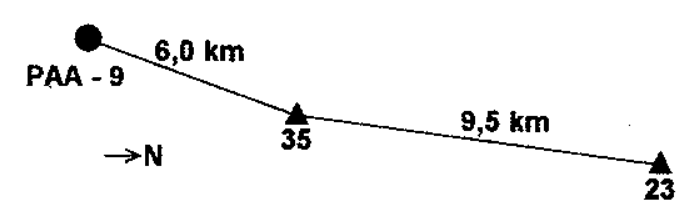

$$
\text { G }
$$


Os processos de brechamento por variação de volume são principalmente penecontemporâneos a deposição, estando ligados à desidratação e hidratação de sais (tepee e pseudoanticlíneo), dessecamento de pelitos e calcilutitos (e.g. gretas de contração), que atuam quando o sedimento recém depositado fica exposto ou com recobrimento pouco espesso.

Os processos químicos e físico-químicos podem atuar em qualquer momento da formação da rocha. No presente caso, considerou-se a atuação de tais processos após a deposição, sendo responsável pela presença de poros preenchidos por calcita, com cristais atingindo até alguns milímetros, originados da dissolução e precipitação e/ou recristalização direta do carbonato de cálcio presente nos fragmentos de brecha (Prancha 6 - Fotos 24 e 25), ocupando espaços gerados pela própria dissolução ou ainda fraturas ou vazios deixados durante a geração da brecha.

Processos hidrodinâmicos ligados a correntes aquosas ocasionais de alta energia, geradas em tempestades e/ou maremotos, também devem ter atuado na geração desta fácies, devendo ser os responsáveis por rearranjo de clastos e orientações destes.

Um encadeamento possível dos eventos geradores das brechas seria: exposição de camadas recém-depositadas, onde houve dessecação, a qual provocou variações volumétricas que gretaram os sedimentos, sendo a superfície exposta recoberta por pulso ou vários pulsos de sedimentação, podendo ocorrer fases de exposição, intercalando-se ainda eventos de transporte e rearranjo dos clastos. A atuação de processos químicos diagenéticos teriam então provocado o "incremento" do brechamento, com a formação de calcita em fraturas, sobrepondo-se às características adquiridas na exposição.

As litofácies interbrechas, $\mathrm{Cl}$ e LIm, foram geradas pela precipitação de material em suspensão em condições de baixa energia.

A litofácies $A i$, que sucede as brechas da litofácies $\mathrm{Ba}$, apresentam intraclastos que dentro da camada diminuem de tamanho e na freqüência. A presença destes intraclastos foi interpretada como indicativa da atuação de processos físicos trativos de transporte de material. Também indica uma aumento significativo em relação à porção inferior da sucessão dominada por pelitos, depositando predominantemente areia. Os intraclastos foram retrabalhados de porções gretadas ainda expostas, semelhantes as litofácies $\mathrm{Bl}$ e Ba.

Em várias ocorrências, na parte inferior da sucessão $A$ esta presente apenas uma camada de brechas com matriz pelítica (litofácies BI), seguida da aparente gradação $\mathrm{Ba} \rightarrow \mathrm{Ai} \rightarrow \mathrm{Am}$.

A sucessão A é limitada no topo por uma superfície plana e regular. Na base, - limite foi estabelecido na primeira camada de brecha próximo ao contato, no sentido 
Passa Dois $\rightarrow$ Pirambóia.

\subsection{Intervalo correspondente à base da Formação Pirambóia}

As litofácies Ac e Ap são mormente constituídas por arenitos, diferenciando-se quanto a aspectos texturais e quanto as estruturas sedimentares.

A litofácies Ac apresenta, como característica marcante, laminação cruzada do tipo tangencial na base, disposta em sets, sugerindo a atuação de correntes de alta velocidade, suficientes para movimentar as particulas arenosas. Os truncamentos da parte superior dos sets e as variação de direção dos estratos cruzados demonstram uma certa variabilidade na direção de atuação das correntes responsáveis pela deposição (item 4.5.2.).

A litofácies Ap apresentam predominantemente estratificações plano-paralelas com sets centimétricos e confinados de laminação cruzada. Também neste caso é evidente a atuação de corrente direcional trativa, porém as condições diferem das existentes na litofácies Ap. O presente caso sugere a princípio correntes com velocidades muito altas, as quais não permitiram a deposição em estratos cruzados.

Estas duas litofácies constituem camadas métricas a decamétricas, intercalado-se verticalmente em sucessão do tipo Ac-Ap, como observados em campo. O contato entre as litofácies é abrupto. 


\section{INTERPRETAÇÕES GENÉTICAS DOS DEPÓSITOS}

Até o momento foram apresentadas as interpretações baseadas nos aspectos físicos das rochas encontradas, chegando-se a definição de litofácies e a combinação destas, as sucessões de fácies.

Neste item serão feitas considerações sobre os possiveis gêneses das litofácies e das sucessões de fácies e inferências sobre aiguns aspectos paleoambientais e paleogeográficos.

\subsection{Ambiente de planícies de maré em mar epicontinental raso}

Há um consenso entre a maioria dos autores (e.g. Petri \& Coimbra 1982, Zalán et. al. 1990, Lavina 1991) que existiu, durante a maior parte do Permiano, um mar epicontinental, extenso, raso, com gradientes baixos e parte do tempo isolado do oceano.

Nas margens deste mar, desenvolveram-se, segundo Suguio et. al. (1974), Petri \& Coimbra (1982), Melo e Sousa (1985), planícies de maré, onde foram depositados sedimentos siliciclásticos e carbonáticos, com características compatíveis com este tipo de ambiente costeiro, entre elas a predominância de sedimentos pelíticos, estruturas que evidenciam exposição freqüente e presença de estromatólitos.

Particularmente na Formação Teresina, tem-se como um dos exemplos mais completos de depósitos considerados como de planícies de maré, os que ocorrem na região de Taguaí (Suguio et al 1974 e Petri \& Coimbra 1982, Coimbra et al. 1994), onde foram reconhecidos: zonas de inframaré (calcários oolíticos), intermaré (acamamento heterolítico) e supramaré (gretas de contração, tepees embrionários); áreas submersas protegidas da ação de correntes (esteiras microbianas); e tempestitos (calcário oolítico com estratificação do tipo hummocky). Vários intervalos das unidades Teresina, Corumbatai e Serrinha apresentam as mesmas características. Os depósitos siliciclásticos destas unidades também apresentam várias texturas e estruturas semelhantes às dos depósitos carbonáticos.

Mais recentemente foram questionados por Lavina (1991) e Rohn (1995) os processos regidos por marés como os responsáveis pela geração dos depósito Teresina, Corumbataí e Serrinha. Aqueles autores apresentaram, como alternativa, processos controlados na maior parte por ondas, geradas por ventos e tempestades, os quais formariam depósitos semelhantes aos das planícies de maré. O maior obstáculo para a atuação de correntes de maré seria, segundo aqueles autores, a pequena profundidade e os baixos gradiente. 
Realmente, as pequenas profundidades atribuídas ao mar epicontinental seriam um obstáculo para o desenvolvimento de correntes de maré significativas, devido principalmente ao atrito com o fundo. Outro fator importante seria o possivel isolamento deste mar do oceano. Entretanto deve ser lembrado que a mesma dificuldade de propagação enfrentada pela maré, que pode ser considerada uma onda de comprimento da ordem de centenas a milhares de quilometros e com altísssima energia (Brown et. al. 1989), também são enfrentadas por ondas de grande amplitude e comprimento, geradas em tempestades ou maremotos. Mesmo ondas geradas por ventanias $(14 \mathrm{~m} / \mathrm{s}$ a $28 \mathrm{~m} / \mathrm{s})$ ou brisas $(13,8 \mathrm{~m} / \mathrm{s}$ a $1,6 \mathrm{~m} / \mathrm{s})$, escala Beaufort, com amplitudes entre $12 \mathrm{~m}$ e $0,3 \mathrm{~m}$, podem também podem ter sua propagação afetada pelo atrito com o fundo, amplificado pelos baixos gradientes, típicos de mares epicontinentais.

Klein (1982 apud Fraser 1989) argumenta que em mares rasos isolados, as marés também dependem da extensão da bacia, ou seja, quanto maior a área inundada mais significativa seria a maré. $O$ mar epicontinental aqui tratado parece satisfazer esta condição, pois, medindo-se a distância entre as bordas atuais do Grupo Passa Dois, $1500 \mathrm{~km}$ seria a extensão mínima do eixo maior e $600 \mathrm{~km}$ a do eixo menor (considerando-se ainda que o mar recobria a maior parte desta área ao mesmo tempo). Além disso, a amplitude da maré é diretamente proporcional a profundidade máxima do corpo aquoso (Howarth 1982 apud Fraser 1989). Este parâmetro é raramente discutido pelos autores que defendem a ausência de correntes de maré significativas.

Os modelos existentes para depósitos de ambientes rasos e de baixa energia, estão, em vários trabalhos (e.g. Reading 1986, Walker \& James 1992), divididos segundo sua composição (siliciclásticos ou carbonáticos) e condições climáticas (árido ou úmido).

Para as rochas carbonáticas os modelos apresentados mais freqüentes são os de sucessão mais rasas rumo ao topo (shallowing upward succession). Segundo James (1984) e Pratt et al. (1992), uma sucessão ideal seria formada pelo empilhamento contíno, rumo ao topo, de sedimento de inframré, intermaré, supramaré e continental (sedimentos expostos a intemperismos). Ainda segundo James (1984), estas sucessões seriam mais condicionadas por altas taxas de sedimentaçăo, que excedem a de subsidência, do que por reduções da área de influência de corpos aquosos (regressões).

Dois tipos extremos de planície de maré são conhecidos (Schreiber 1986; Sellwood 1986), baseados em elementos morfológicos e climáticos: (1) o com zona de intermaré com muitos canais e pequenos corpos aquosos (ponds), bordejada por zona de supramaré bem drenada e com desenvolvimento de mangues em clima úmido; e (2) o com zona de intermaré com poucos canais, bordejada por zona de supramaré, seca, 
em clima árido. Neste último podem desenvolver-se depósitos evaporíticos diagenéticos nas zonas de intermaré (gipso) e supramaré (anidrita e halita), recebendo a denominação de sabkha. O desenvolvimento de nódulos e cristais em poros pode provocar rompimento dos depósitos hospedeiros (Kendall 1984). O tepee é uma estrutura bastante particular deste tipo de ambiente e forma-se pelo rompimento do sedimento ou de esteiras microbianas pela hidratação de sais em poros ou ainda pela força lateral de crescimento de cristais de sais depositados em poros (Schreiber 1986).

Os modelos siliciclásticos são geralmente apresentados adjacentes a lagunas em sistemas de ilhas-barreira, associados a estuários ou ainda, mais raramente em margens oceânicas. Pode apresentar sucessões granodescrescentes ascendentes, depositando areia em porções de inframaré, lama em porções de supramaré e intercalando areia e lama em porções de intermaré (Elliot 1986, Dalrymple 1992). Podem estar também intercalados, em depósitos pelíticos de porções mais rasas (supramaré), camadas de arenito originados por tempestades (Reison 1984).

As litofácies descritas no topo das unidades Teresina, Corumbataí e Rio do Rasto (Membro Serrinha) e nas brechas do contato: LIm, Afl, Cl, Ca, Bl e Ba, puderam ser interpretadas em um contexto de planícies de maré, desenvolvida nas costas do mar epicontinental entäo existente.

Litoácies constituídas por sedimentos pelíticos e micríticos (litofácies LIm e Cl respectivamente), são comuns em zonas de inframaré superior a supramaré, sítios de deposição típicos destes tipos de sedimentos, onde predominam condições de baixa capacidade de transporte e de processos de decantação de finos (Sellwood 1986, Fraser 1989), podendo haver ainda condições favoráveis para o desenvolvimento de esteiras microbianas, as quais necessitam de zonas protegidas, sem correntes fortes, para que as frágeis lâminas gelatinosas que constituem a esteira viva possam ser preservadas.

As zonas de intermaré inferior e de inframaré são as mais sujeitas a correntes fortes devido a maior profundidade e ao maior tempo de submersão. Nestas zonas podem ser depositadas areias (litofácies $\mathrm{Afl}$ ) ou oólitos (litofácies $\mathrm{Ca}$ ). A ação de correntes oscilatórias pode gerar ondulações na superfície dos sedimentos ou mesmo coordenar a deposição em sets relacionados a sua migração. Variações na direção podem também ocasionar truncamentos por reativação de superfícies.

Camadas constituídas por carapaças de ostracodes foram consideradas como produto da ação de correntes geradas em tempestades (alta e instantânea dissipação de energia), já enfraquecidas pela proximidade com a costa, mas suficientes para concentrar as carapaças, evento pouco comum em condições normais de correntes de maré em zona de intermaré.

As camadas de "pé-de-moleque" da litofácies $S$ foram interpretadas como possíveis depósitos evaporíticos, originados em sabkha litorâneo (intermaré superior e 
supramaré). O processo de formação de depósitos evaporíticos está ligado à concentração por evaporação de águas que geram soluções concentradas (salmouras) favorecendo a precipitação de sais. Em áreas mais afastadas e protegidas, zonas de intermaré superior a supramaré, as salmouras são concentradas em pequenas lagunas (tidal ponds) ou ainda próximo à superfície na zona vadosa em sedimento hospedeiro. Nesta última situação é comum a precipitação de evaporitos nodulares (gipso ou anidrita). As camadas com textura "pé-de-moleque" assemelhamse quanto à forma e distribuição aos depósitos nodulares de gipso (Rouchy 1979), que se formam nas porções mais baixas da zona de supramaré, ou seja, zonas com maior contato com água (Kendall 1984). A posterior substituição por sílex pode ter ocorrido ainda na diagênese precoce, onde condições físico-químicas favoráveis para a deposição de silex, como a rápida diluição de salmouras por águas doces ou menos salinas. Tal processo foi proposto por Salvany et al (1994) para depósitos de gipso silicificado na Bacia do Ebro, Espanha.

Tais depósitos, mais do que fornecer informações sobre possível sítio de deposição, apontam para a existência de condições climáticas áridas e a presença de salmouras.

Ainda em ambiente de planície de maré em clima árido é bastante comum a formação de microbialitos em zonas próximas de sabkhas (Schreiber 1986). O contato com salmouras pode ter favorecido o surgimento e crescimento de nódulos evaporíticos em eventuais espaços vazios entre lâminas.

A sucessão A apresentou características que permitiram interpretá-la com originada em zonas de intermaré superior a supramaré, onde os processos de exposição são mais freqüentes, com inundações e deposições menos freqüentes.

No intervalo inferior da sucessão $A$ ocorre, intercalados as brechas (litofácies $\mathrm{BI}$ ), sedimentos como micritos (litofácies $\mathrm{Cl}$ ) e ainda pelitos (litofácies $\mathrm{LIm}$ ). Tal intercalação (Figura 11, pontos $01,06,10,13,15,20,44$ ) foi considerada uma evidência marcante da continuidade dos processos comuns as porções de intermaré sucedidos por condições de supramaré, nas quais as brechas foram geradas. Isto significa também a continuidade da influência do mar epicontinental na deposição. Outros autores como Almeida \& Barbosa (1953) e Soares (1973) consideraram este intervalo como de origem subaérea, gerando solos em período de exposição. Nos pontos 10,13,15 e 44 (Figura 11), pôde-se notar ciclicidade dos processos acima descritos, com até sete pares de camadas de brecha e de interbrecha (Figura 11, ponto 15). Nos demais pontos há apenas uma camada de brecha representando a parte inferior da sucessão.

Deve ser entendido que as camadas interbrecha foram geradas em condições de intermaré, ou seja, deposição de sedimentos finos, sem longas exposições. As camadas de brecha também foram inicialmente geradas em condições de intermaré, 
onde depositaram-se micritos, micritos fossiliferos ou pelitos, posteriormente expostos e gretados. $O$ alto grau de fragmentação e o grande espectro de tamanhos de intraclastos (de alguns milimetros até $20 \mathrm{~cm}$ ) e a espessura de mais de dois metros em alguns casos, apontam para uma provável geração policíclica, ou seja, mais de uma geração de gretamentos e mais de uma geração de deposição embutidos em cada camada de brecha. Estas intercalações de camadas brechadas e não-brechas, podem ter origem em variaçōes do nivel do mar, provocadas por mudanças climáticas. O mar isolado, como considerado por Lavina (1991) e Rohn (1995), seria bastante sensível a tais variações.

A parte superior da sucessão A, que está representada por uma gradação aparentemente entre brecha e arenito (litofácies $B a \rightarrow A i \rightarrow A m$ ), está inserida num contexto diferente. Estes sedimentos foram considerados como depositados em condições energéticas mais altas que a parte inferior, sendo notório o aumento de siliciclásticos rumo ao topo

Nas porções mais altas da zona de supramaré foram depositados materiais trazidos por ondas de tempestade, que tinham disponíveis, além de areia, fragmentos oriundos de planícies expostas e gretadas.

Woods \& Brown (1975) reconheceram em zonas de supramaré, do Nilemah Embayment (Shark Bay, Australia), sedimentos intraclásticos gradando de brechas (clastos de $10 \mathrm{~cm}$ a $30 \mathrm{~cm}$ ) para areias progressivamente mais finas, no sentido mar $\rightarrow$ continente. Tais depósitos seriam originados do por retrabalhamento de material por ondas de tempestade.

A parte superior da sucessão A parece registrar este tipo de distribuição, onde verticalmente sucedem-se sedimentos cada vez mais finos, podendo ser atribuídos a porções progressivamente mais altas da zona de supramaré.

O aumento de siliciclásticos rumo ao topo, foi causado pela possível proximidade das zonas de supramaré com áreas contínentais adjacentes, onde já poderiam estar atuando processos eólicos.

A sucessão A conteria então os registros finais do mar epicontinental na área estudada.

\subsection{Mares de areia}

A combinação de dois fatores são essenciais para a formação e conservação de depósitos eólicos de areia: a existência de área subsidente e suprimento de material (Miall 1992). Sem subsidência os sedimentos acumulados dificilmente seriam fixados, sendo novamento levados pelos ventos. O suprimento de material para as áreas de deposição determina a taxa de acúmulo de sedimentos. A ação de ventos com pouco ou nenhum suprimento tende a originar áreas de deflação. A granulometria 
e o regime de ventos são determinantes da forma e evolução dos depósitos eólicos(Brookfield 1984).

Os depósitos de areias são referidos como mares de areia (sand seas) e representam $20 \%$ da área total de um sistema desértico atual.

Segundo Collinson (1986), três tamanhos diferentes de corpos arenosos podem ser encontrados: draas, os de maior escala, dunas, que trafegam sobre as draas e por fim ondulações que migram em cima das dunas.

As ondulações podem ocorrer sobre dunas e em zonas de interdunas. Suas formas são geralmente de baixo relevo e de crista reta, sendo o principal processo que rege seu movimento o de saltitação de grãos. Um tipo particular de ondulação é a de adesão, comuns as zonas de interdunas, onde ocorrem superfícies úmidas, nas quais os grãos aderem.

As dunas, estruturas maiores, podem apresentar formas variadas, as quais são condicionadas pelo suprimento, velocidade e direções dos ventos. Quatro tipos podem ser reconhecidos: formas transversais de crista reta ou curvas (barcanas); formas parabólicas de frente convexa, associadas a regiões úmidas e com vegetação; e formas longitudinais, com cristas paralelas às direções dos ventos.

As draas, corpos de escala maior que as dunas, apresentam formas parecidas às das dunas, porém mais complexas e compostas (Brookfield 1984).

Entre corpos como dunas e draas podem ser desenvolvidos, com o devido suprimento de areia, (Collinson, 1984) as interdunas e interdraas. Kocurek (1981) relacionou três tipos diferentes de interdunas: a seca $(d r y)$ onde podem predominar a deposição de areias por ação dos ventos, gerando ondulações, sem entretanto serem desenvolvidas dunas e podendo eventualmente tornar-se uma superfície de deflação quando o suprimento torna-se pequeno; interdunas úmidas (damp), onde a superfície está freqüentemente úmida, devido à proximidade do lençol freático com a superfície, e onde é possível as adesões de grãos e o desenvolvimento de vida, registrada na forma de bioturbações; e por último as aquosas (wet), onde podem ser desenvolvidas várias das estruturas comuns a corpos aquosos como lagos ou ainda drenagens.

Hunter (1977) reconheceu em corpos arenosos os seguintes tipos mais freqüentes de laminações:

Laminação plana: produto de ventos de alta velocidade, não permitindo a formação de ondulações. A laminação surge por variações de velocidade e/ou suprimento.

Laminação ondulada traslatent: constituí-se do registro da migração de ondulações cavalgantes, podendo ser o cavalgamento em ângulo maior ou menor que o de barla-vento. Os de ângulo maior (supercríticas) apresentam laminações cruzadas (porções sotavento) e registram altas taxas de acúmulo de material. Os de ângulo menor (subcrítico) produzem laminações bem definidas, milimétrica sem registros da 
porção de sotavento (estratificações cruzadas).

Laminação por queda de grãos: ocorre a partir da crista do corpo eólico, por segregação de fluxo, que favorece a deposição do material em suspensão ou proveniente da saltitação. a seleção pode ser pobre e dificultar o reconhecimento de laminações.

Laminação por fluxo de grãos: altos ângulos em frentes de dunas podem favorecer processos de avalanche (ou de fluxo de grãos), com segregação granulométrica, formando corpos lingüiformes ou cônicos. Em corte vertical, transversal à frente da duna, tais lâminas aparecem na forma de lâminas e em cortes verticais paralelos a frente da duna apresentam forma lenticular, ou tabular se amalgamadas.

As superfícies geradas pela migração de corpos eólicos constituem outro elemento importante utilizado na classificação de corpos éolicos (muito útil em depósitos antigos). Brookfield (1977) apresentou a seguinte classificação:

Superficies de primeira ordem: ligadas à migração de draas, trunca todas as demais estruturas são geralmente de baixo ângulo.

Superficies de segunda ordem: são confinadas entre superfícies de primeira ordem, apresentando mergulhos na direção do vento. São geradas pela migração de dunas.

Superfície de terceira ordem : são limitadas por superfícies de segunda ordem. São geradas pela erosão e reinício da deposição, quando há variações locais na direção do vento.

As litofácies Ap e Ac puderam ser interpretadas como originadas em contexto eólico de deposicão de areias.

A litofácies Ac apresenta laminação interna proveniente de processos de queda de grãos, com seleção boa a moderada e laminações provenientes de processos de fluxo de grãos (avalanches), de seção lenticular em corte vertical paralelo à frente de duna (prancha 6 - Foto 27), com seleção localmente variando de boa a muito boa. Estas lâminas compõem conjuntos de estratificação cruzada (sets), geralmente tangencial na base e truncada no topo. Estes conjuntos foram interpretados como provenientes de variações na direção dos ventos sendo então as superfícies de truncamento entre eles, característica de terceira ordem. Estes conjuntos de lâminas estão confinados entre duas superfícies relativamente planas, que representam então superfícies de segunda ordem, ou seja, superfícies geradas por migração de dunas.

O estudo do comportamento dos conjuntos de lâminas, quanto ao sentido de mergulho, permitiu o estabelecimento de possiveis direções relativas de atuação dos paleoventos (item 4.5.2).

Em interdunas secas ocorrem estruturas de baixo ângulo de origem eólica, 
com processos de queda de grãos e migração de ôndulações. A litofácies At, dentro do contexto eólico admitido, constitui os depósitos de interdunas do tipo seca, com estratos de baixo ângulo. Estes depósitos ocorrem na forma de camada com espessuras de $3 \mathrm{~m}$ a $5 \mathrm{~m}$, limitada por superfícies de truncamento, em contato com camadas da litofácies Ac.

Nos afloramentos estudados foi observada, com exceção da exposição perto de Charqueada (ponto 37), a sucessão Ac-Ap, a partir do topo das brechas do contato.

O primeiro trabalho a relatar a existência de depósitos eólicos na Formação Pirambóia foi o de Washburne (1929), em resumo apresentado no American Association of Geologists Bulletin, onde reconheceu sedimentos eólicos e fluviais intercalados. Já em seu trabalho sobre a geologia de petróleo do Estado de São Paulo, publicado em 1930 pela Comissão Geográfica e Geológica do Estado de São Paulo, a interpretação foi somente de depósitos fluviais.

Soares (1973), apresentou um dos principais trabalhos na linha de interpretação de depósitos originados exclusivamente por processos fluviais, reconhecendo depósitos de canal e de transbordamento em sistema meandrante.

Lavina (1991) retomou a gênese eólica, considerando ambientes eólicos na deposição Pirambóia intercalados com depósitos lacustres do topo do Rio do Rasto.

Caetano-Chang et al. (1991) desenvolveram trabalhos na Formação Pirambóia, no municipio de São Pedro, São Paulo, onde caracterizaram fácies eólicas como dunas e interdunas.

\subsection{Interpretação paleoclimática}

Através da identificação de argilominerais, do reconhecimento de depósitos característicos foi possivel reconhecer uma tendência de aridez climática durante a deposição do intervalo estudado.

Ramos \& Formoso (1975) reconheceram, baseados em estudos de dados de amostras de subsuperfície, que a illita está sempre presente nas unidades permianas (Corumbataí, Teresina e Rio do Rasto), sendo rara nas formações Pirambóia e Botucatu. A esmectita é predominante nas unidades Teresina, Corumbataí, Rio do Rasto (detrítica para o topo), Pirambóia e Botucatu, sendo de origem detrítica para estas duas últimas unidades. Clorita é comum na Formação Teresina, rara e excludente com esmectita na Formação Corumbataí, rara e associada a interestratificados 10-14M (illita-esmectita) nas formações Rio do Rasto e Botucatu. Estes autores destacam ainda o aparecimento de corrensita na Formação Teresina e na base da Formação Rio do Rasto, principalmente em zonas de calcários oolíticos.

A predominância de esmectita detrítica nas formações Pirambóia e Botucatu e 
nos topos das unidades Teresina, Corumbataí e Membro Serrinha indicaria, ainda segundo Ramos \& Formoso (1975), contribuição de áreas-fonte de clima semi-árido.

Também baseados em dados de subsuperfície, Rodrigues \& Quadros (1976), apresentaram mapas de distribuição dos argilominerais (Figura 12A) e de teor de boro (Figura 12B) do intervalo Formação Ponta Grossa - Formação Rio do Rasto. $O$ teor de boro varia conforme 0 ambiente aquoso: sedimentos depositados em água doce são mais pobres em boro do que aqueles depositados em água mais salgada como a marinha (Potter et al. 1963).

Em vários intervalos das formações Teresina e Corumbataí e Rio do Rasto (Membro Serrinha), estão presentes esmectita e illita próximo às bordas atuais e em boa parte da bacia no Estado de São Paulo, enquanto que na porção sudoeste do estado aparecem clorita, illita e corrensita. Concluem Rodrigues \& Quadros (1976) que a distribuição generalizada de esmectita e interestratificados, a presença de corrensita, geralmente associada a ambientes mais ricos em magnésio (Millot 1970) e os altos teores de boro (Figura 12B) nas formações Teresina e Corumbataí, principalmente de suas seções médias rumo aos topos, indicariam os estágios finais de uma regressão do corpo aquoso epicontinental sob condições de forte evaporação.

Uma superposição dos mapas de distribuição de argilominerais e de teores de boro (Figura 12C) de Rodrigues \& Quadros (1976) mostrou relação entre isoteores de boro e áreas definidas pela distribuição de argilominerais específicos, sugerindo que a paleossalinidade foi um dos fatores controladores da ocorrência de determinados argilominerais ao longo da bacia. Esmectita e illita ocorrem preferencialmente nas bordas da bacia, onde encontram-se os mais altos teores de boro. A associação illita, clorita e interestratificados aparece onde ocorrem teores médios de boro. Illita e clorita (sem esmectita) restringem-se às porções mais centrais da bacia, onde os teores de boro são os mais baixos.

As amostras provenientes de afloramentos das unidades Teresina, Corumbataí e Pirambóia analisadas por difração de raios $X$ apresentam esmectita como o grupo argilomineral predominante (Tabela 2), sendo a característica mais marcante as distâncias no intervalo entre $14 \AA$ e $15 \AA$. Tal predomínio deste argilomineral foi confirmado em imagens obtidas com MEV, onde foram observadas placas bem desenvolvidas, levemente onduladas nas bordas (Prancha 7 - Fotos 28 a 33).

Também outros grupos de argilominerais foram identificados através da difratometria de raios $\mathrm{X}$ : a) illita presente na maioria das amostras; b) caulinita na Formação Pirambóia; c) indícios de palygorskita em rochas das brechas do contato e da Formação Teresina. Pela microscoscopia eletrônica de varredura foi observada halloysita (grupo da caulinita) na forma de tubos desenvolvidos nas pontas de placas de esmectita (Prancha 7 - Foto 32) e clorita na forma de placas (Prancha 7 - Foto 33) sendo estas duas ocorrências na Formação Pirambóia. 

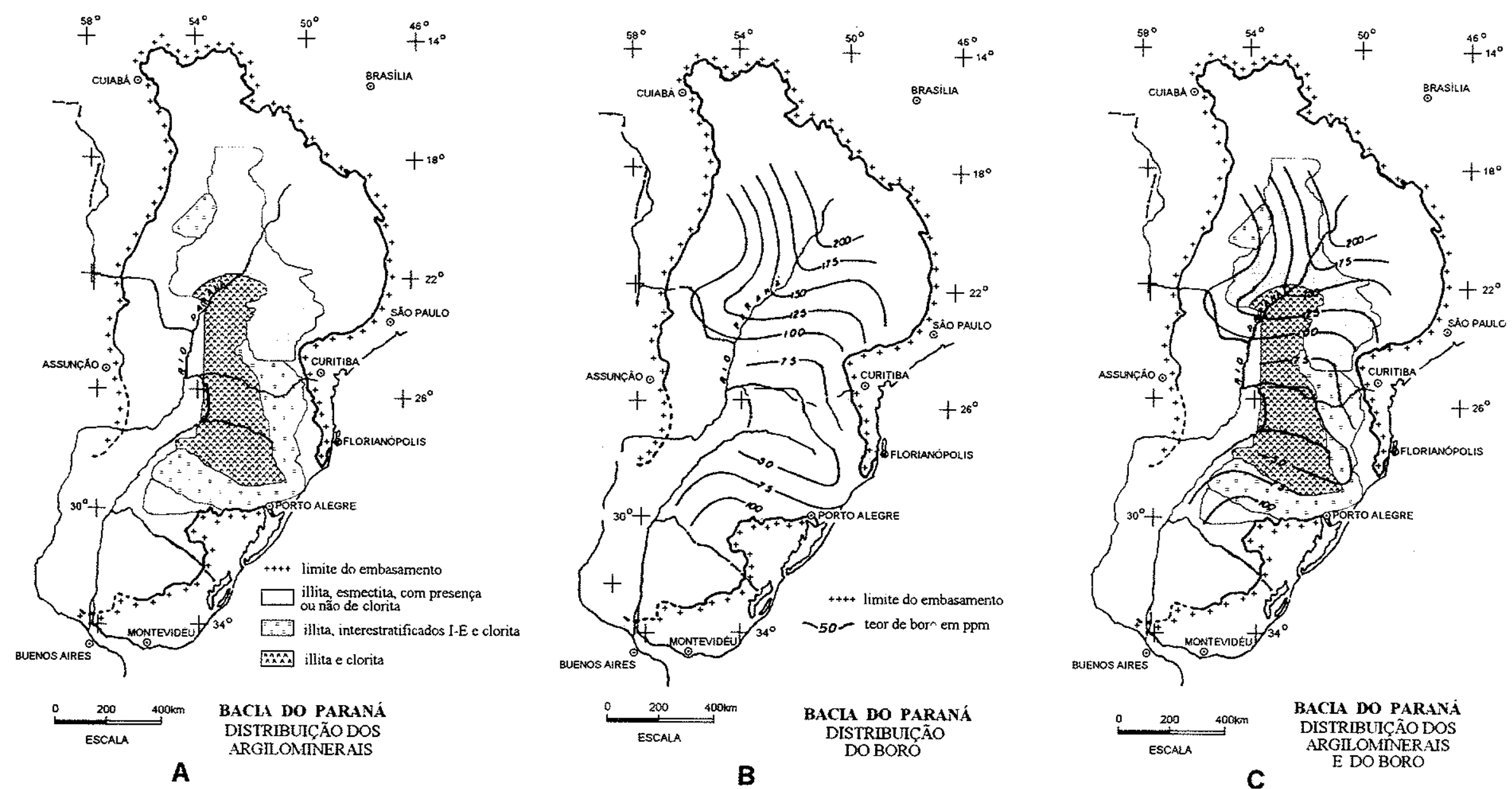

Figura 12: A - Distribuição dos argilominerais das unidades Corumbataí, Teresina e Rio do Rasto (segundo Rodrigues \& Quadros 1976);

B - Curvas de isoteores de boro das unidades Corumbatai, Teresina e Rio do Rasto (segundo Rodrigues \& Quadros 1976);

C - Sobreposição da distribuição dos argilominerais e curvas de isoteores de boro das formações Corumbataí, Teresina e Rio do Rasto (Membro Serrinha). Observar a relação entre as isolinhas de teor de boro e os contornos das áreas de ocorrência dos argilominerais. 
As atuais formas de esmectitas, originalmente detríticas, apresenta desenvolvimento diagenético das bordas de placas, gerando formas delicadas, de difícil conservação em transporte. A presença de esmectita detrítica ou produto de diagênese precoce (eodiagênese) indica condições de semi-aridez climática e drenagem ineficaz no sítio deposicional.

A não observação em imagens de MEV de illita, caulinita e palygorskita, identificadas através da análise de difratogramas de raios $X$, deve ser conseqüência de suas pequenas proporções.

A possível existência de depósitos evaporíticos (atualmente silicificados) e a ocorrência de textura radial em oólitos, tal como reconhecida por Coimbra (1990) e Coimbra et al. 1994) em calcarenítos oolíticos da região de Taguaí, indicam a existência de condições de hipersalinidade. O processo de concentração de sais por evaporação é característico em corpos aquosos isolados ou com pouca circulação de água, em clima com tendência à áridez.

Suguio et al. (1974) e Rodrigues \& Quadros (1976), também já apontaram condições de evaporação intensa em clima árido durante a deposição dos sedimentos das formações Teresina e Corumbataí, baseando-se nos teores do isótopo mais pesado do oxigênio $\left(\mathrm{O}^{18}\right)$ e na elevação relativa dos teores de boro principalmente da porção média para o topo.

O clima ainda continuou árido na continentalização e desertificação da bacia durante a deposição das unidades Pirambóia e Botucatu.

A presença de vegetal pouco pôde colaborar na identificação do clima predominante no sítio deposicional. Além de não ter sido achado em posição de vida, o pequeno fragmento de psaronídeo pouco poderia informar sobre seu local de vida, já que uma correlação direta com seus parentes atuais, comuns em regiões úmidas $e$ relativamente quentes, seria pouco adequada, pois não há informações sobre outras partes do vegetal (como folhas ou a superfície externa do caule).

Por outro lado, baseando-se nas características do fragmento de caule do espécime, semelhantes a parte interna de formas viventes, admite-se que esta parte do vegetal não suportaria transporte e/ou exposição prolongados, apontando a necessidade de permineralização logo após sua morte para ser preservado, indicando condições de alta concentração de sílica no sítio de deposição durante este evento. A pequena ou inexistente deformação do fragmento indica que a permineralização deve ter ocorrido antes do espécime ter sido sepultado ou quando recoberto por fina camada de sedimentos. 


\subsection{Contexto paleotectônico}

Alguns autores identificariam na passagem Passa Dois-Pirambóia uma variação no comportamento tectônico da bacia, baseados em uma possível desconformidade existente entre as unidades Passa Dois e São Bento.

Almeida (1981) apontou "comportamento tectônico quiescente" durante a deposição das unidades Irati, Serra Alta, Teresina e Rio do Rasto, seguido de ascensão epirogênica e instalação de processos erosivos, sem a possibilidade de fixação dos produtos destes. A fixação de sedimentos só se reiniciaria no Triássico, em ambiente tectônico calmo com deposição exclusivamente continental.

Zalán et al. (1990) também apontaram um período de soerguimento no final do Permiano ligado à orogenia Finiherciniana, com parada na sedimentação, a qual reiniciar-se-ia somente no Mesotriássico em ambiente flúvio-lacustre.

Particularmente no Estado de São Paulo, Soares (1973) interpretou o acunhamento das unidades neopermianas, verificado em perfil SW-NE obtido com dados de sondagem, como conseqüência da "peneplanização pré-Pirambóia", reflexo de acentuado soerguimento da porção central do Estado de São Paulo em relação ao Arco de Ponta Grossa.

No Estado de São Paulo é marcante a feição conhecida por "Depressão Deposicional de São Paulo", reconhecida por Northfleet et al. (1969). Tal feição constitui um embaciamento que condicionou a deposição das unidades sedimentares dos grupos Passa Dois e São Bento (Figuras 13A e 13B).

Sobre a paleogeografia, Hachiro \& Coimbra (1992) consideraram esta área de maior "embaciamento" da Bacia do Paraná no Estado de São Paulo como a responsável pela origem do vasto golfo durante a deposição dos sedimentos do Subgrupo Irati. A presença de depósitos evaporíticos e de taxas relativamente altas de salinidade (teores de boro elevados) indicam a provável continuidade do corpo aquoso epicontinental semi-restrito, descrito por Hachiro \& Coimbra (1992), evoluindo para um corpo aquoso em extinção durante a deposição final dos sedimentos das formações Teresina, Corumbataí e Rio do Rasto (Membro Serrinha).

A inferência a discordância erosiva no contato Passa Dois - Pirambóia foi baseada, em boa parte, na inexistência de depósitos típicos da Formação Rio do Rasto nas porções centro e norte do Estado de São Paulo, interpretada como depositada e posteriormente retirada por erosão, possívelmente através de levantamentos tectônicos pré-Pirambóia.

Um possivel levantamento tectônico no eixo transversal (WNW) do "embaciamento de São Paulo" (durante a deposição final do Grupo Passa Dois e início da deposição da Formação Pirambóia) seria a causa principal da remoção de partes 

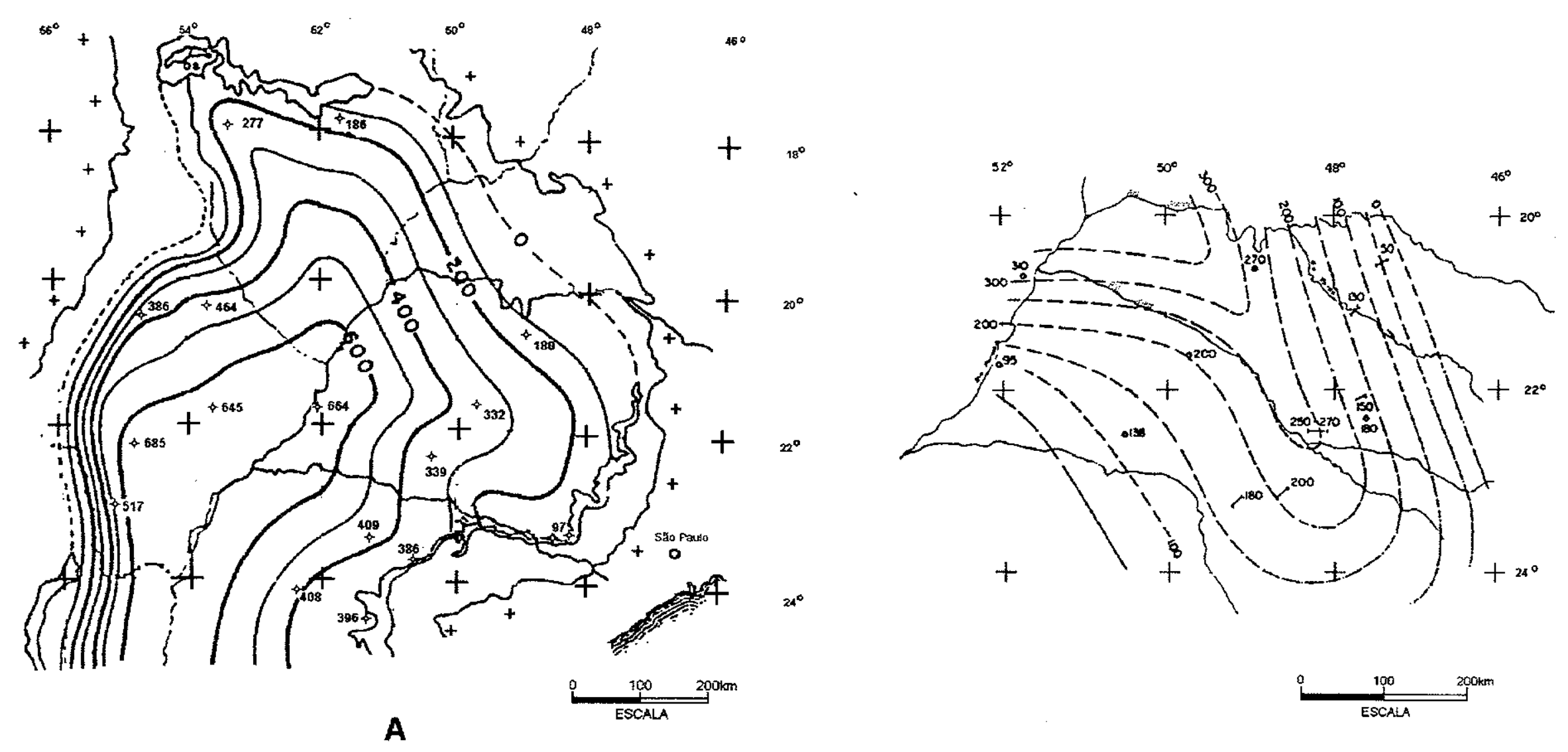

B

Figura 13: A - Mapa de isópacas das formaçōes Teresina, Corumbataí e Rio do Rasto - Membro Serrinha (segundo Northfleet et al. 1969);

B - Mapa de isópacas da Formação Pirambóia (segundo Soares 1973). 
das unidades Corumbataí, Teresina e Rio do Rasto. Esta hipotese, tal como aventada por Melo e Sousa (1985), pôde ser descartada pela observação das isópacas das unidades (Figuras 13A e 13B). Há indícios de que na porção central do Estado de São Paulo persistiu uma depressão onde ocorrem as maiores espessuras destas unidades, feição ativa também durante a deposição das unidades Pirambóia e Botucatu.

Neste contexto, os depósitos das brechas do contato representam os episódios finais de atuação do corpo aquoso epicontinental nas áreas estudadas, sem desníveis que permitissem remoção de material por ele depositado. O sistema deposicional eólico também foi condicionado pela depressão, continuando a criação de espaço e assim permitindo acúmulo e fixação dos sedimentos.

\subsection{Hidrotermalismo}

O primeiro relato sobre as estruturas silicosas de Anhembi deve-se a Soares (1972), que as interpretou como estromatólitos cônicos e hemisferóides, cuja presença em sedimentos da Formação Teresina seria, ainda segundo aquele autor, compatível com os sedimentos de planícies de maré descritos na unidade.

Entretanto, várias feições destas estruturas levaram a uma reinterpretação de sua gênese, permitindo considerá-las como resultado de atividade hidrotermal em superfície. Dentre estas feições citam-se: as formas cônicas, a presença de um cilindro central com textura vesicular contrastando com a textura maciça do resto da estrutura, a existência de vazios internos em forma de abóboda e a continuidade abaixo da laje de sílex. Estas características são comparáveis às dos geiseritos encontrados no Yellowstone Park, localizado da região noroeste do Estado do Wyoming, EUA, onde a constante expulsão de água quente rica em sílica dissolvida resulta em três formas diferentes de gêiseres: (1) cones semelhantes aos encontrados em Anhembi; (2) piscinas em forma de funil; e (3) gêiseres escalonados com água corrente, constituindo piscinas em vários niveis diferentes (Bouer 1947, White 1967, Fournier et al. 1992).

\subsubsection{Origem e funcionamento dos gêiseres}

O processo de erupção dos gêiseres ocorre, segundo White (1967), quando águas de origem meteórica, penetrando centenas de metros no subsolo através de descontinuidades nas rochas (falhas ou fraturas) ou ainda através de rochas permeáveis (zonas de recarga de aqüiferos), são aquecidas a temperaturas maiores que $200^{\circ} \mathrm{C}$, muito acima da temperatura de ebulição da água em superfície, sendo isto possível pelas altas pressões em subsuperfície. A ascenção desta água aquecida 
e sua ebulição devida à diminuição de pressão próxima à superfície resulta nas fontes termais. Enquanto em algumas ocorrências o vapor é liberado por escape calmo e constante, em outras há uma quantidade excessiva de vapor para ser perdido por esta forma. Assim, de tempos em tempos, este vapor em exesso eleva a água, impulsionado-a para cima e para fora da abertura, ocorrendo assim uma queda de pressão nos níveis mais inferiores, incrementando a ebulição e iniciando uma reação em cadeia que provoca a erupção, sendo este tipo de fonte chamada de gêiser (Figura 14).

Dentro da interpretação proposta, os corpos de Anhembi constituiriam estruturas edificadas pela precipitação de sílica ao redor de extintas aberturas de escape de água. O cilindro central composto por material silicificado com porosidade vesicular foi interpretado como o duto de escape dos gêiseres, preenchido por detritos, introduzidos pelo próprio gêiser, por material introduzido durante o soterramento dos corpos (a silicificação destes materiais seria posterior à sua introdução), ou ainda por sílica depositada por águas que ficariam paradas no duto. Outros cilindros encontrados em certos corpos indicam mais de um duto de escape ou dutos que substituíram o original quando este foi obstruído.

A camada de sílex na base dos corpos, onde ocorrem nódulos de sílex, seria conseqüência da formação de pequenos corpos aquosos ao redor dos gêiseres.

\subsubsection{Idade e gênese dos geiseritos de Anhembi}

A questão mais importante para a definição da idade dos geiseritos é a identificação de quando houve a exposição da superfície sobre a qual os cones foram edificados, superfície esta correspondente a uma laje decimétrica de sílex, existindo continuidade dos corpos abaixo desta. A laje encontra-se em sedimentos da Formação Teresina, em área de exposição restrita à feição conhecida como Domo de Anhembi. Esta estrutura pertence, segundo Soares (1974), ao conjunto de estruturas dômicas da Bacia do Paraná, ativas no período anterior à deposição Bauru. Compõem a estrutura três blocos movimentados diferencialmente, separados por falhas verticais, sendo que uma delas encontra-se injetada por dique de diabásio.

Duas hipóteses foram admitidas para explicar esta ocorrência de geiseritos: a) construção dos geiseritos dentro do intervalo de tempo de deposição da Formação Teresina; b) construção ligada a hidrotermalismo, após evento de exumação da Formação Teresina. Nas duas hipóteses, a instalação em sedimentos Teresina foi considerada mais do que um acaso. Estes sedimentos são predominantemente pelíticos e calcilutíticos, menos permeáveis, o que favorece um fluxo confinado, com menor perda de pressão ao longo de falhas e fraturas.

A primeira hipótese sugere a construção dos geiseritos durante evento de 

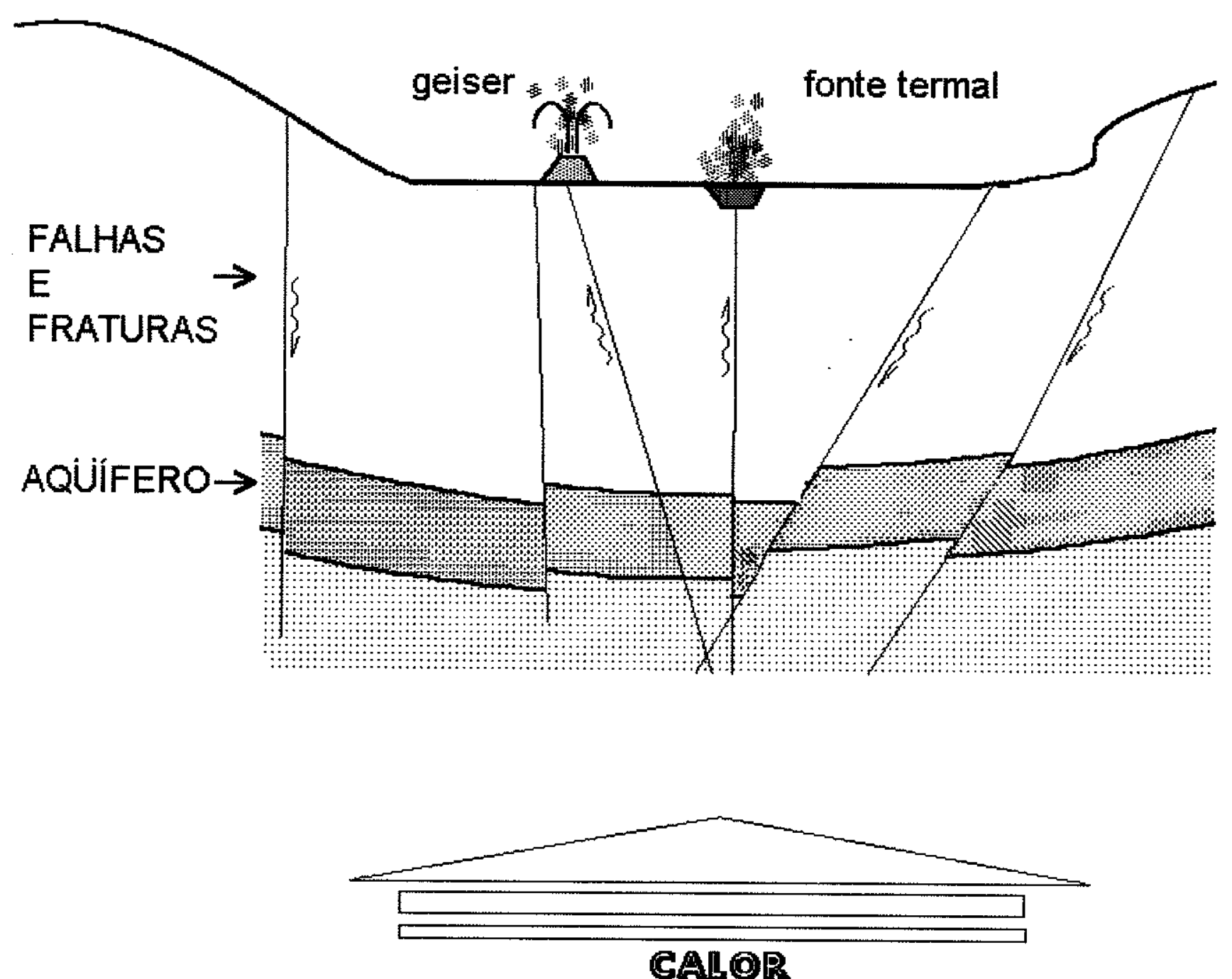

Figura 14:

Modelo genérico de um sistema hidrotermal em profundidade, abastecido por águas de origem meteórica, resultando, após aquecimento e transporte para a superfície, em gêiseres e fontes termais (segundo White 1967 e Gupta 1980). No desenho não houve preocupação com a geometria das falhas ou com a proporcionalidade. As setas indicam um possivel padrão de circulação de água no sistema. 
hidrotermalismo no intervalo de tempo correspondente à deposição da Formação Teresina. Porém, para que isto possa ter acontecido, seriam necessárias algumas condições comuns às ocorrências de gêiseres atualmente conhecidas.

Marler \& White (1975) e White (1991) observaram que gêiseres do tipocolunar (ou cônico) são construídos onde as rochas próximas à superfície são competentes, não facilmente fragmentadas, enquanto os formas do tipo piscina em forma de funil tendem a se instalar onde as rochas próximas à superfície são menos resistentes e podem ser facilmente quebradas e ejetadas.

A presença de gêiseres colunares em Anhembi indicaria então a existência de uma camada superficial com resistência suficiente para não ser rompida durante as erupções, supondo-se que deva ter ocorrido um ganho de resistência em evento diagenético anterior.

Também seria necessária a emersão desta superfície, ou seja, a ausência do mar epicontinental nesta área, pois condições suaquosas comprometeriam não só a deposição de sílica, pela diluição quase imediata da água expelida, como o próprio funcionamento dos gêiseres, com a possibilidade de refluxos constantes de água fria.

Outra condição para o funcionamento dos gêiseres é a existência de fonte de calor que alimente com energia o sistema hidrotermal. A maioria das bacias geiseríticas conhecidas estão relacionadas a câmaras magmáticas rasas, como o Yellowstone Park nos EUA ou o Geysir Group na Islândia (Waring 1965). Porém, já foram relatadas excessões como os Beowawe Geysers, no Estado de Nevada, EUA, onde não foram encontradas evidências de corpos magmáticos rasos (White 1992), apesar da ocorrência de geiseritos colunares ativos.

$\mathrm{Na}$ área ocupada pela Bacia do Paraná, não foi relatada até o momento a existência de atividade vulcânica ou câmara magmática rasa neopermianas ou eotriássicas.

A atividade sísmica é mais uma das características das áreas de ocorrência de gêiseres, influindo diretamente na geração das falhas e fraturas responsáveis pelo transporte de água até a superfície (Bauer 1947, Maler 1964, MacDonald 1972 e Merler \& White 1975).

Em sedimentos da Formação Corumbataí, correlata da Formação Teresina no extremo norte da bacia, Riccomini et al. (1992) reconheceram feições de liquefação, induzidas por abalos sísmicos, penecontemporâneas a deposição, na forma de diques clásticos em depósitos marinhos rasos. Tais sismos estariam relacionados, segundo aqueles autores, aos pulsos iniciais do processo de ruptura do Gondwana. Também Fernandes \& Coimbra (1993) apresentaram indícios marcantes da atuação de sismos em sedimentos do topo da Formação Rio do Rasto, também neopermiana em parte, no Estado do Paraná; tais indícios constituem-se de níveis de espessura decimétrica com estratificação contorcida. Landim (1970) reconheceu "estruturas de 
deformação e perturbação pós-deposicionais" na Formação Corumbataí, entre Piracicaba e São Pedro (centro-leste do Estado de São Paulo), as quais denominou de "estruturas interpregueadas", interpretando-as como camadas submetidas a uma oscilação qualquer. Segundo Dzulynsk \& Smith (1963) tal oscilação também deve ser de origem sísmica.

Tal atividade sísmica no intervalo de tempo, no qual os geiseritos de Anhembi podem ter-se desenvolvido, teria sido responsável pelo seu aparecimento e abastecimento. Também é possível que a atividade sísmica tenha suprido a ausência de fonte de calor rasa, com desconfinamento de água em fraturas ou em aquíferos (Sibson et al. 1975, Sibson 1981) em processo semelhante ao descrito por lijima (1969 apud Tsuneishi \& Nakamura 1970), que relatou a ocorrência de expulsão de água ao longo da zona de falha (cerca de $10^{7} \mathrm{~m}^{3}$ ) próxima a cidade de Matsushiro, Japão, durante período de atividade sísmica intensa.

A segunda hipótese, que considera o evento hidrotermal registrado no Grupo Bauru também responsável pelo surgimento dos geiseritos de Anhembi, respalda-se na proposta de Coimbra et al. (1981), que admitiram a ocorrência de atividade hidrotermal concomitante à sedimentação Bauru na Serra de Itaqueri, onde águas termais carregadas em sílica penetraram através de fraturas, provocando a formação de opala. A ausência de evidências de digestão de clastos e as deformações sofridas pelas opalas seriam evidências de sua possivel formação sincrônica à deposição. Tal atividade hidrotermal estaria, ainda segundo Coimbra et al. (1981), associada ao Alinhamento do Rio Mogi Guaçu, de direção N20\% W. No prolongamento deste alinhamento encontram-se corpos de rochas alcalinas, Jaboticabal ao norte e Araçoiaba da Serra a Sudeste.

A exposição da Formação Teresina poderia então ter ocorrido por exumação durante o levantameno do Domo de Anhembi.

Ainda não foram encontrados elementos que permitam excluir alguma das hipóteses apresentadas. A hipótese de atividade hidrotermal neopermiana-eotriássica carece ainda de evidências, como a existência de geiseritos recobertos por sedimentos das formações Teresina ou Pirambóia, o que atestaria sua idade. No caso de atividade hidrotermal eocretácica são necessárias mais evidências da seqüência de eventos de alçamento do Domo de Anhembi, exumação da Formação Teresina e a atividade hidrotermal que afetou o Grupo Bauru. 


\section{ESTABELECIMENTO DE NOVA UNIDADE LITOESTRATIGRÁFICA: CAMADA PORANGABA}

O intervalo que contém o contato Passa Dois-Pirambóia, marcado pelas brechas do contato, tem boa parte de suas atuais características originadas em transformações pós-deposicionais (precoces ou tardios) de rochas semelhantes as dos topos das formações Corumbataí, Teresina e Rio do Rasto (ítens 4.1, 4.2 e 4.3).

Estes aspectos apontaram a impropriedade da interpretação das brechas do contato como "depósitos basais iniciais" da unidade Pirambóia, pois tratam-se de depósitos com composições e gêneses diferentes.

Assim, sugere-se que o intervalo passe a integrar os topos das formações Corumbataí, Teresina e Rio do Rasto, ficando então o contato do topo destas unidades com a base da Formação Pirambóia, marcado pela superfície plana, limite do topo das brechas, a qual foi reconhecida na maioria das exposições estudadas do contato.

Propõe-se também o estabelecimento de uma nova unidade litoestratigráfica, com hierarquia de camada, constituída pelo intervalo até o momento denominado de brechas do contato.

(1) Justificativa - o intervalo compreendido pelas brechas do contato vem sendo utilizado, desde o início dos estudos sistemáticos da Bacia do Paraná no Estado de São Paulo, como marco estratigráfico do contato entre o topo do Grupo Passa Dois e a base da Formação Pirambóia.

(2) Seleção do nome - o nome geográfico selecionado para compor a denominação da nova unidade foi do município no qual se encontra sua seção-tipo, em corte da rodovia Castelo Branco (SP 280 - sentido capital-interior), km 166,5, sendo ele 0 de Porangaba. Este nome não aparece denominando nenhuma das unidades relacionadas em Baptista et al. (1984), nem em Schobenhaus (1984), obras mais abrangentes sobre unidades litoestratigráficas existentes no Brasil.

A utilização de termo litológico, baseado no litotipo mais característico, neste caso brecha, traria confusões com outros intervalos das unidades sotopostas, além de ser forte lembrança do antigo conceito de "brecha da base" da unidade Pirambóia, reinterpretado de maneira diferente no presente trabalho.

Optou-se assim pela denominação composta pelo termo hierárquico mais o termo geográfico. Para o presente caso, o Código Brasileiro de Nomenclatura Estratigráfica aconselha a categoria de "camada", passando a denominar-se Camada Porangaba as brechas do contato. 
(3) Caracterização de área tipo e localização do estratótipo - a ocorrência mais característica da Camada Porangaba aparece em cortes às margens da rodovia Castelo Branco, entre os quilometros 166,5 e 167, dentro do território do município de Porangaba. Destas exposições foi escolhido como holoestratótipo, o afloramento do lado direito da pista capital-interior no km 166,5. (Ponto 15, Figura 1)

(4) Descrição das características da unidade - as características distintivas da unidade foram apresentadas nos ítens 4.2 e 5.1. Dentre elas destacam-se: as intercalações de camadas de brecha e camadas de micritos e pelitos, da base até a porção média. Desta porção para o topo, há uma transição de brecha para arenitos pelíticos com intraclastos, terminando com arenito pelítico. Esta transição é uma das características mais marcante da Camada Porangaba e ocorre em todas as exposições conhecidas, onde o perfil foi encontrado completo. A porção inferior foi a que apresentou a maior variaçäo de espessura.

(5) Fixação dos limites - o contato superior com a base da Formação Pirambóia se dá de maneira abrupta por superfície plana e regular, a qual separa os arenitos pelíticos com estrutura maciça dos arenitos médios e finos, com pouca matriz pelítica e organizados em estratos tabulares internamente laminados na forma cruzada. 0 contato basal foi definido arbitrariamente como a primeira camada de brecha da base do intervalo de intercalações de brechas e camadas não brechadas das unidades Teresina, Corumbatai e Serrinha.

A existência de brechas intraformacionais em porções intermediárias da Formação Teresina poderia ser confundida com a Camada Porangaba, devendo ser usados como critérios distintivos a proximidade com a unidade Pirambóia e a transição brecha-arenito pelítico, a partir da porção média da camada.

A continuidade lateral da camada foi de difícil rastreamento, dada a distribição pontual dos dados de subsuperfície e de superfície. Sua ausência foi notada nas regiões de Batovi (ponto 14), a oeste de Anhembi (poços PAA-10 e PAA-11) e próximo a Charqueada (ponto 37).

(4) Dimensão e forma - a Camada Porangaba varia quanto a espessura, de 60 $\mathrm{cm}$ a $2,5 \mathrm{~m}$ em afloramentos e $30 \mathrm{~cm}$ a $4,8 \mathrm{~m}$ em poços. Sua forma é tabular na escala de afloramento, porém, como mostram os dados dos poços, há variações acentuadas na escala quilométrica (Figuras 1 e 11), aparentando forma de cunha, mais estreita no sentido do centro da bacia.

(7) Correlação, idade e gênese - A porção inferior da Camada Porangaba (correspondente à parte inferior da sucessão A) foi gerada pela deposição em porções de inter e supramaré, e posterior transformação de sedimentos semelhantes aos dos topos das unidades Corumbataí, Teresina e Rio do Rasto. A porção superior da Camada Porangaba (correspondente à parte superior da sucessão A) foi gerada em porções mais afastadas das linhas de costa rumo ao continente, sem a existência de 
desniveis que permitissem a remoção de material. Isto permite interpretar que, na área hoje compreendida pelo Estado de São Paulo, as sedimentações Corumbataí, Teresina e Rio do Rasto, principaimente aquosas, continuavam em porções mais centrais e restritas da bacia e enquanto que em regiões periféricas iniciava-se a deposição Pirambóia.

A questão idade é ainda motivo de controvérsias, tanto para a unidade Pirambóia, como para as unidades Corumbataí, Teresina e Serrinha (item 3.3), o que impede o estabelecimento de uma idade para a Camada Porangaba. Pode-se considerá-la apenas como inserida dentro do intervalo de tempo compreendido entre o Neopermiano e o Eotriássico. Ressalta-se que no presente trabalho constatou-se a inexistência de hiatos significativos nas passagens topo do Grupo Passa Dois para a base do Pirambóia, o que deve ser considerado indicativo de idades próximas entre tais unidades.

A Camada Porangaba é restrita ao Estado de São Paulo e pode ser correlacionada ao topo da Formação Rio do Rasto, Membro Serrinha, de outras regiões.

Esta unidade está sobreposta aos topos de unidades distintas, Teresina, Corumbataí e Serrinha, o que segundo o Código Brasileiro de Nomenclatura Estratigráfica (Petri et al. 1985), artigo B7, inciso segundo, não caracteriza impedimento para o estabelecimento de camada com características distintivas claras. Também sua gênese ligada em parte a eventos pós-deposicionais não implica em obstáculo, já que a gênese não pode ser critério para a constituição de unidades litoestratigráficas (artigo B1 inciso primeiro).

O principal objetivo do estabelecimento desta unidade foi facilitar as futuras citações e discussões deste intervalo, pois constitui-se de pacote rochoso particular, sendo uma referência clara para o contato Passa Dois-Pirambóia, melhor do que os termos "brechas da base", ou "regolito fóssil", usadas até o presente.

A tabela 5 apresenta um resumo das características do intervalo estudado relacionando: litofácies, unidades litoestratigráficas, produtos, processos geradores das litofácies, interpretação paleoambiental e ambientes deposicionais principais. 


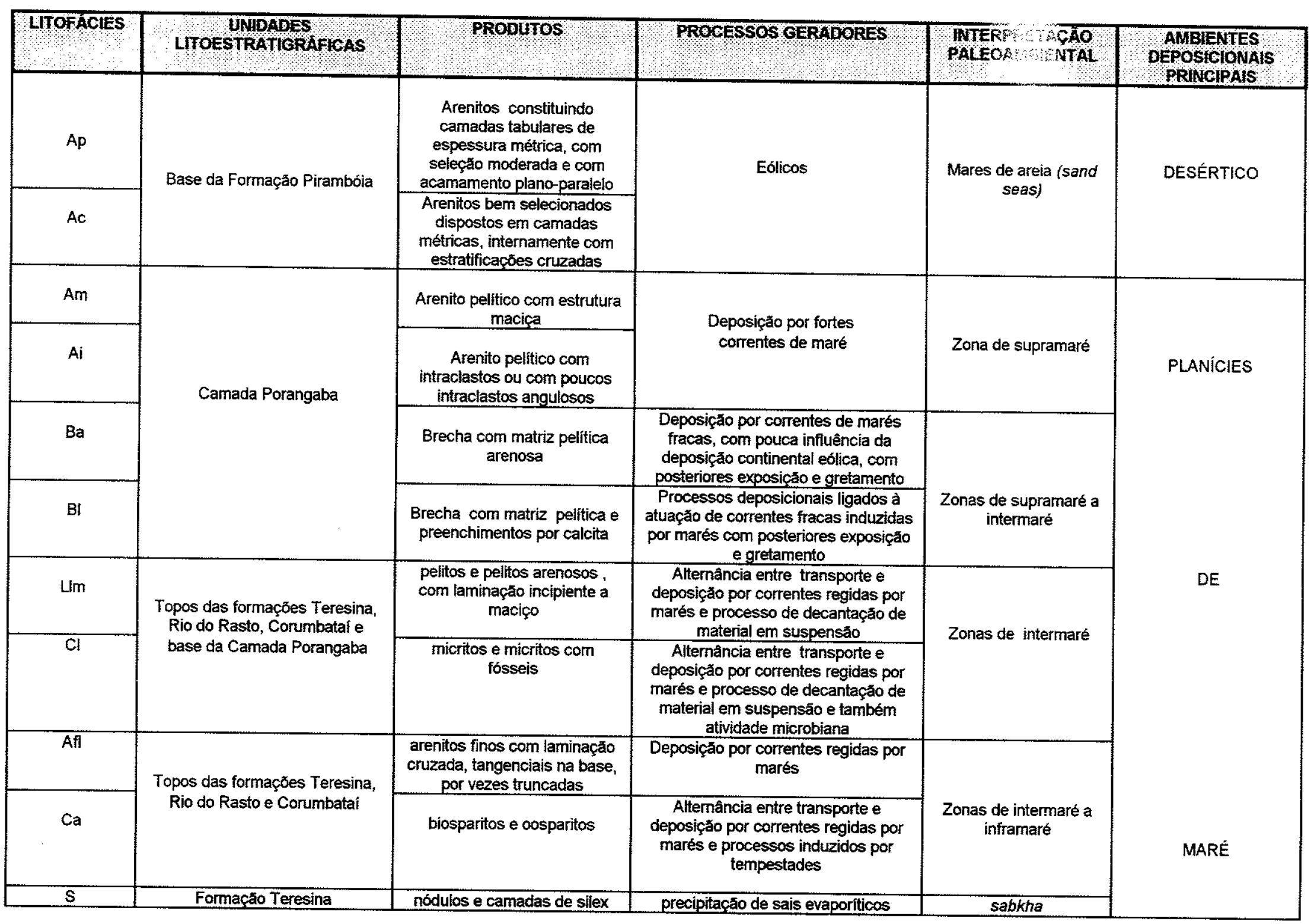
Tabela 5: Quadro relacionando: fácies, unidades litoestratigráficas, produtos, processos geradores, interpretação paleoambiental
e ambientes sedimentares principais. 


\section{O CONTATO PASSA DOIS-PIRAMBÓIA E AS SEQÜÊNCIAS ESTRATIGRÁFICAS}

\subsection{Trabalhos anteriores}

O contato entre as unidades Passa Dois e São Bento foi adotado como limite de seqüências por ser interpretado como uma discordância de âmbito geral da bacia, marcada por grande hiato erosivo e/ou deposicional. Soares et al. (1974) utilizaram este contato como limite entre a Seqüência Delta e a Seqüência Delta $A$, definidas segundo o conceito de Seqüências Estratigráficas de Sloss (1963). Neste conceito as seqüências estratigráficas são unidades de grau mais alto que supergrupo, limitadas por discordâncias reconhecidas em bacias ao longo de todo o craton, sendo que cada seqüência representa um ciclo transgressivo-regressivo completo, regido por ciclo de depressão do craton abaixo do nível de base e posterior emersão. Outros exemplos mais antigos de propostas de divisão em seqüências dos depósitos da Bacia do Paraná, baseadas no conceito de Sloss (1963), foram Gomes (1968) e Almeida (1969) e encontram-se representados na figura 15.

Zalán et al. (1990), valendo-se do conceito de "sintemas" de Chang (1975), dividiram o pacote sedimentar da Bacia do Paraná em cinco destas unidades, denominadas de Siluriana, Devoniana, Permo-Carbonífera, Triássica e Juro-Cretácea.

Lavina (1991) dividiu os depósitos da Bacia do Paraná do intervalo compreendido entre o Neocarbonífero e o Eotriássico em seqüências deposicionais, utilizando a conceituação de Mitchum et al. (1977 apud Ojeda 1988). Segundo esta conceituação: "seqüência deposicional é uma unidade estratigráfica composta por sucessão de estratos concordantes, relacionados geneticamente, limitados no topo e na base por discordâncias ou suas concordâncias relativas, tendo também significado cronoestratigráfico".

Particularmente para a passagem Passa Dois-Pirambóia no Estado de São Paulo, Lavina (1991) interpretou um período de "onlap alto", no qual foi depositada a porção superior da unidade Corumbataí, seguindo-se "uma queda do onlap", com desenvolvimento de truncamento erosional e por fim "uma elevação do onlap", com a deposição da unidade Pirambóia. O modelo evolutivo de Lavina (1991) apresentou como importante contribuição, a incorporação da transição existente entre as unidades Rio do Rasto e Pirambóia, evidência desprezada em vários trabalhos de âmbito geral da bacia (e.g. Zalán et al. 1990). Este modelo, mesmo apresentado como hipotético pelo autor, necessitaria da seguinte discussão e complementação de dados: a) evidências de erosão do topo da unidade Corumbataí nas porções marginais da bacia, 


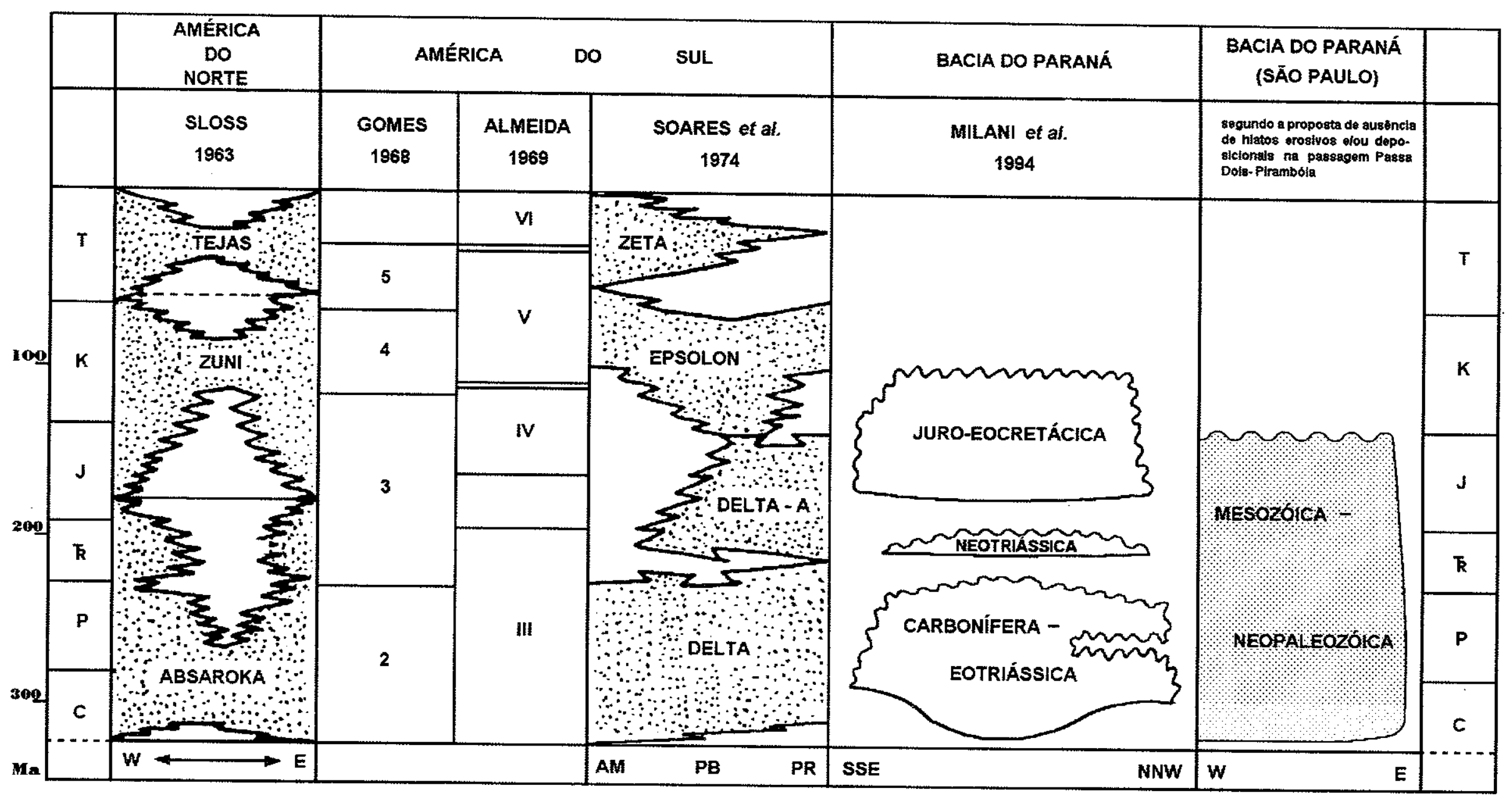

Figura 15: Seqüências estratigráficas reconhecidas na Bacia do Paraná. 
antes do início da deposição Pirambóia; b) detalhes quanto aos mecanismos que teriam ocasionado as variações de onlap; e c) dados de paleocorrentes e das áreasfonte dos sedimentos.

Milani et al. (1994) apresentaram divisão em seis seqüências estratigráficas limitadas por expressivas desconformidades: Ordoviciana-Siluriana, Devoniana, Carbonífera-Eotriássica, Neotriássica, Juro-Eocretácica e Neocretácica. Esta proposta representa uma evolução da proposta de Zalán et al. (1990), principalmente em relação à idade dos depósitos. Uma das mais importante mudança foi a atribuição de idade eotriássica para a porção final do Grupo Passa Dois (figura 15)

Recentemente Rohn (1995) apresentou proposta de divisão do Grupo Passa Dois em "intervalos", baseada em perfis geofísicos de poços (perfilagens) e somada a dados paleontológicos e litológicos. Um dos principais critérios adotado pela autora foi o de estabelecimento de limites em picos radioativos (perfis de raios $\gamma$ ) de menor intensidade, delimitando formas de funil. Tais intervalos foram interpretados como seqüências granodecrescentes, que alinhadas, seriam capazes de mostrar "histórias batimétricas similares", parte do mesmo ciclo de variação do "nível de base". Assim, estariam estabelecidas unidades isócronas. Este critério condicionou a autora citada a interpretar um hiato maior do que dez milhões de anos, entre o topo da Formação Corumbataí e a base da Formação Pirambóia, pois estariam ausentes sete dos 10 "intervalos" presentes nas unidades Teresina e Rio do Rasto nos estados do Paraná e Santa Catarina

\subsection{O significado do contato}

Os contatos Teresina-Camada Porangaba e Corumbataí-Camada Porangaba são transicionais, pois há a intercalação de camadas não brechadas com características semelhantes às presentes nestas unidades com brechas geradas em processos pós-deposicionais. Os contatos Camada Porangaba-Pirambóia (Prancha 9 Fotos 36 e 37) e Corumbataí-Pirambóia são planos e litologicamente abruptos (Prancha 9 - Fotos 38 e 39), sugerindo uma troca brusca de ambiente, sem entretanto implicar em volumosas erosões ou exposições mais prolongadas que permitissem desenvolvimento de solos.

Isto indica uma proximidade cronológica entre a deposição final Passa Dois e inicial Pirambóia. Os sedimentos eólicos fixaram-se sobre as antigas planícies de maré, em direção ao centro da bacia, acompanhando o recuo do corpo aquoso adjacente.

A instalação da deposição eólica acompanhou o processo de redução da área ocupada pelo corpo aquoso epicontinental, o qual terminou junto com o final da 
deposição Rio do Rasto.

A presença de estruturas relacionadas a eventos sísmicos pode indicar idades próximas entre os depósitos das formações Teresina, Corumbataí, Rio do Rasto e Pirambóia, pois parecem obedecer os critérios de Sims (1975) para a correlação de tais tipos de estrutura: a) restrição a um único intervalo estratigráfico e separação por camadas não deformadas; b) possibilidade de correlacão ao longo de grandes áreas; c) presença de horizontes planos e não afetados por processos de escorregamento.

A possivel existência de correlação cronológica entre as formações Rio do Rasto, Pirambóia, Rosário do Sul e Misiones (esta no Paraguai), já foi admitida por Petri \& Fúlfaro (1983). Também Ragonha (1989) e Lavina (1991) interpretaram a simultaneidade na deposição das unidades do topo do Grupo Passa Dois e da base do grupo São Bento.

Estes elementos permitiram questionar a existência da discordância tão utilizada como evidência de hiato erosivo e/ou deposicional entre a seqüência marinha carbonífera-permiana e a seqüência continental mesozóica.

Com a soma das evidências de transição entre depósitos Rio do Rasto e Pirambóia em áreas centrais da bacia e da presente interpretação do contato, foi possivel considerar a possibilidade de existência de uma seqüência estratigráfica do tipo de Sloss (1963) constituída por depósitos dos grupos Tubarão, Passa Dois e sedimentos do São Bento, unidades Pirambóia e Botucatu, estas representando o estágio final do preenchimento, por sedimentos continentais predominantemente é́licos, recobrindo as planícies de maré, sem provocar erosão e sem permitir exposição prolongada (Figura 15). A Formação Serra Geral representa o evento magmático efusivo em momento tectônico diferente, existindo opiniōes sobre a existência de discordância erosiva anterior ao evento (Leinz 1949, Eik et al. 1973).

$\mathrm{Na}$ utilização dos conceitos de Posamentier et al. (1987 apud Ojeda 1988) deve-se observar a inexistência de hiato deposicional acentuado entre o final da deposição em planícies de maré, quando do recuo do corpo aquoso, e início da deposição eólica. Este seria um dos elementos necessários para o estabelecimento de um limite de seqüência do tipo 2 (Posamentier et al. 1988 apud Walker 1992), ou seja, exposição subaérea prolongada com deslocamento do onlap costeiro abaixo da quebra da linha de praia deposicional (local situado na plataforma, a partir da qual, na direção do continente, a superfície deposicional encontra-se ao nivel de base ou próximo dele e, em direção à bacia, estaria abaixo do nivel de base) sem ocorrência de rejuvenescimento de drenagens e com o deslocamento das fácies deposicionais para o interior da bacia. Lavina (1991) chegou a estabelecer um limite do tipo 1 entre as unidades Corumbataí e Pirambóia considerando a existência de hiato deposicional e erosivo nas margens da bacia. 


\section{CONSIDERAÇÕES FINAIS}

A Camada Porangaba constitue o elemento mais característico presente no contato Passa Dois-Pirambóia da Bacia do Paraná no Estado de São Paulo, tanto em afloramentos na borda leste como em perfurações que demonstraram certa continuidade da camada, rumo ao centro da bacia. Do reconhecimento da atuação de processos comuns às planícies de maré na deposição da camada foi possível concluir que ela deu-se, da base para o topo, em zonas mais altas, progressivamente mais afastadas da linha de costa rumo às terras então emersas. Estas interpretações, somadas às características litológicas da unidade e às suas relações de contato, posicionaram a Camada Porangaba como pertencente ao conjunto de rochas do Grupo Passa Dois.

A feição negativa que deu origem ao embaciamento, abrigou o corpo aquoso epicontinental, com planícies de maré associadas a leste, palco da deposição dos sedimentos das unidades Corumbataí, Teresina e Serrinha, persistiu durante a deposição dos sedimentos do Grupo São Bento (formações Pirambóia e Botucatu), indicando a ausência de levantamentos acentuados, que promovessem a remoção de material.

A gênese da Camada Porangaba permitiu ainda reconhecer a inexistência de hiato expressivo no contato, mostrando uma sedimentação praticamente contínua, onde anteriormente eram reconhecidas feições e produtos de erosão. Esta camada mantém contato abrupto com a base da Formação Pirambóia, o qual marca uma passagem da deposição regida por marés para a regida por ventos. Tal mudança deuse quando o corpo aquoso recuou permitindo o avanço da deposição eólica.

Os ventos responsáveis pela deposição Pirambóia sopraram, no momento inicial, nos sentidos $S W \Rightarrow N E$ e $S E \Leftrightarrow N W$ na porção sul e sudoeste da área e $N \leftrightharpoons S$ e $N W \Rightarrow S E$ nas porções nordeste e central, o que sugeriu, ainda preliminarmente, uma zona de convergência.

O clima predominante no sítio deposicional era então árido a semi-árido, como demonstraram os argilominerais encontrados, teores de boro e ainda a presença de sedimentos indicativos de hipersalinidade como oólitos fibrorradiados e possíveis depósitos evaporíticos.

As evidências de atividade hidrotermal na região de Anhembi, na forma de cones silicosos não teve ainda sua idade definida, a qual poderá ser desvenda com a confirmação de uma das hipóteses apresentadas para sua gênese.

A continuidade na sedimentação em porção considerada de borda ou muito próxima desta e também a ocorrência de transição em porções mais centrais da Bacia indicam uma possibilidade de existência de uma grande seqüência estratigráfica, do 
tipo definida por Sloss (1963), com registro sedimentar contínuo, que uniria então as sequências designadas de Delta (grupos Tubarão e Passa Dois) e de Delta A (sedimentos do Grupo São Bento) por Soares et al. (1974). 


\section{BIBLIOGRAFIA}

ADAMS, A.E.; MACKENZIE,M.; GUILFORD,C.-1984- Atlas of sedimentary rocks under the microscope. Essex, Longman Scientific \& Technical. 104p.

ALLEN, J.R.L.-1987- Sedimentary structures. Oxford, Elsevier. 1256p.

ALMEIDA, F.F.M. DE -1954- Botucatu, um deserto triássico na América do Sul. Rio de Janeiro. Notas Preliminares e Estudos. Divisăo de Geologia e Mineralogia. Departamento Nacional da Produçáo Mineral, v.86, p. 1-21.

ALMEIDA, F.F.M. DE -1964- Fundamentos geológicos do relevo paulista. Boletim do Instituto Geográfico e Geológico, v. 41, p. 169-263.

ALMEIDA, F.F.M. DE -1969- Diferenciação tectônica da Plataforma brasileira. In: CONGRESSO BRASILEIRO DE GEOLOGIA, 23., Salvador, 1969. Anais. Salvador, SBG. p.29-46.

ALMEIDA, F.F.M. DE -1981- Síntese sobre a tectônica da Bacia do Paraná. In: SIMPÓSIO REGIONAL DE GEOLOGIA, 3., São Paulo, 1981. Atas. São Paulo, SBG. v. 1, p. 1-20.

ALMEIDA, F.F.M. DE; BARBOSA, O.-1953- Geologia das quadrículas de Piracicaba e Rio Claro. Rio de Janeiro. Boletim. Divisão de Geologia e Mineralogia. Departamento Nacional da Produção Mineral. v.143, p.1-97.

ALMEIDA, F.F.M. DE; MELO, M.S. DE -1981- A Bacia do Paraná e o vulcanismo mesozóico. In: IPT. Mapa Geologico do Estado de São Paulo, escala 1:500.000. São Paulo, IPT. v.1, p.46-81 (Monografias $\mathrm{n} \underline{0} 6$ ).

ASSINE, M.L.-1993- O eólico e o fluvial na Formação Pirambóia. In: SIMPÓSIO SUL BRASILEIRO DE GEOLOGIA, 5., Curitiba, 1993. Boletim de resumos. Curitiba, SBG. Núcleos PR/SC/RS. p 53-54.

BAPTISTA, M.B.; BRAUN, O.P.G.; CAMPOS, D.A.-1984- Léxico estratigráfico brasileiro. Brasilia, Departamento Nacional da Produção Mineral-CPRM. 560p.

BARBOSA,O.; GOMES, F.A.-1958- Pesquisa de petróleo na Bacia do Rio Corumbataí, Estado de São Paulo. Boletim. Divisão de Geologia e Mineralogia. Departamento Nacional da Produçăo Mineral, v. 171, p. $1-40$.

BAUER, C.M.-1947- Yellowstone geysers. Yellowstone Park, Heynes. 127p.

BIGARELLA, J.J.; SALAMUNI, R.-1961- Early Mezosoic wind patterns as suggested by dune bedding in Botucatu sandstone of Brazil and Uruguay. Geological Society of America Bulletin, v. 72, p. $1089-1106$.

BISTRICHI, C.A.; CARNEIRO, C.D.R.; DANTAS, A.G.S.; PONÇANO, W.L.; CAMPANHA, G.A.C.; NAGATA, N., ALMEIDA, M.A. DE; STEIN, D.P.; MELO, M.S. DE; CREMONINI, O.A.-1981Mapa Geologico do Estado de Såo Paulo, escala 1:500.000. São Paulo, IPT. v. 2 (Monografia no $6)$.

BROOKFIELD, M.E.-1984- Eolian facies. In: WALKER, R.G. (ed.) Facies mode/s. Toronto, Geological Association of Canada. p. 91-105. (Geoscience Canada Reprint Series,1).

BROOKFIELD, M.E.-1977- The origin of bounding surfaces in aeolian sandstones. Sedimentology, v. 24, p. 303-332. 
BROWN, J.; COLLING, A.; PARK, D.; PHILLIPS, D.; ROTHERY, D.; WRIGHT, J.-1989- Waves, Tides and Shallow-water Processes. Walton Hall, The Open University-Pergamon Press. 187p.

BURNE, R.V., MOORE, L.S.-1987- Microbialites: organic-sedimentary deposits of benthic microbial communities. Palaios, v. 2, n. 3, p. 241-254.

CAETANO-CHANG, M.R.; WU, F.T.; BRIGHETTI, J.M.P.-1991- Caracterização eólica de arenitos da Formação Pirambóia, proximidades de São Pedro. In: SIMPÓSIO DE GEOLOGIA DO SUDESTE, 2., São Paulo, 1991. Atas. São Paulo, SBG. p. 53-58.

CHAMANI, M.A.C.; MARTIN, M.A.B.; RICCOMINI, C.-1992- Estruturas de liqüefação induzidas por abalos sísmicos no Permo-Triássico da Bacia do Paraná, Estado de São Paulo, Brasil. In: CONGRESSO BRASILEIRO DE GEOLOGIA, 37., São Paulo, 1992. Boletim de Resumos Expandidos. São Paulo, SBG. v. 2, p. 508-509

COIMBRA, A.M.; BRANDT NETO, M.; COUTINHO, J.M.V. -1981- Silicificação dos arenitos da Formação Bauru no Estado de São Paulo. In: A FORMAÇÃO BAURU NO ESTADO DE SÃO PAULO E REGIÕES ADJACENTES - MESA REDONDA, São Paulo, 1981. Coletánia de trabalhos e debates. São Paulo, SBG. p. 103-111.

COIMBRA, A.M.-1990- A Bacia do Paraná no Estado de Såo Paulo - Roteiro de Excursăo. São Paulo, Departamento de Paleontologia e Estratigrafia/IGc-USP. 44 p. (Roteiro utilizado no curso de sedimentologia).

COIMBRA, A.M.; GÓES, A.M.; HACHIRO, J.; SANT'ANNA, L.G.; HELLMEISTER Jr., Z.; CABRAL Jr., M.; MORAES, M.C. DE; STEFANI, F.L.; VIEIRA, P.C.-1992- Proposta de classificação integrada de rochas sedimentares clásticas. In: CONGRESSO BRASILEIRO DE GEOLOGIA, 37., São Paulo,-1992. Boletim de Resumos Expandidos. São Paulo, SBG. v. 2, p. 419-421.

COIMBRA, A.M.; GÓES, A.M.; MATOS, S.L.F. DE -1993- Classificação de estruturas sedimentares. In: SIMPÓSIO DE GEOLOGIA DO SUDESTE, 3., Rio de Janeiro, 1993. Atas. Rio de Janeiro, SBG. p. 282-285.

COIMBRA, A.M.; HACHIRO, J.; MAZARELLI, S. -1994- Petrologia dos calcários da Formação Teresina, Taguaí, São Paulo. Anais da Academia Brasileira de Ciencias, v. 66, n. 4, p. 497-498.

COLLINSON, J.D. -1986- Deserts. In: READING, H.G. ed. Sedimentary Environments and Facies. 2ed. Oxford, Blackwell. p. 95-112.

COMISSÃO GEOGRÁFICA E GEOLÓGICA -1917- Relatório do ano de 1916. São Paulo, Comissão Geográfica e Geológica do Estado de São Paulo.

COMISSÃO GEOGRÁFICA E GEOLÓGICA -1918- Relatório do ano de 1917. São Paulo, Comissão Geográfica e Geológica do Estado de São Paulo.

CUNHA, P.R.C.; FRANÇA, A.B.-1993- Estudo das taxas de sedimentação das formações Teresina e Rio do Rasto - Bacia do Paraná. In: SIMPÓSIO SOBRE A CRONOESTRATIGRAFIA DA BACIA DO PARANÁ, 1., Rio Claro, 1993. Resumos. Rio Claro, UNESP/SBG. p.77-80.

DAEMON, R.F.; QUADROS, L.P.-1970- Bioestratigrafia do Neopaleozóico da Bacia do Paraná. In: CONGRESSO BRASILEIRO DE GEOLOGIA, 24., Brasilia, 1970. Anais. Brasilia, SBG. p. 359412.

DALRYMPLE, R.W.-1992- Tidal deposicional systems. In: WALKER, R.G.; JAMES, N.P. (ed.) Facies Models - Response to sea level change. Toronto, Geological Association of Canada. p. 195-218.

DERBY, O.A.-1915- Illustrations of the stem structure of Tietea singularis. American Journal of Science. v. 231, p. 251-260.

DUNHAM, R.J.-1962- Classification of carbonate rocks according to deposits texture. In: HAM, W.E. (ed.) Classification of carbonate rocks. American Association of Petroleum Geologists Memoir, 
v. 1, p. $62-84$

DU TOIT, A.L.-1927- A geological comparison of South America with South Africa. Pubication. Carnige Institution of Washington, v. 381, p. 157.

DZULYNSKI, S; SMITH, A.J.-1963. Convolute lamination, its origin, preservation and significance. Journal of Sedimentary Petroly, v. 33, p. 616-627.

EIK, N.C.; GAMERMANN, N.; CARRARO, C.C.-1973. A discordância pré-formação Serra Geral. Pesquisas, v. 2, n. 1, p. 73-74.

ELLIOT, T.-1986. Siliciclastic Shorelines. In: READING, H.G. ed. Sedimentary Environments and Facies. 2ed. Oxford, Blackwell. p.154-188.

FERNANDES, L.A.; COIMBRA, A.M.-1993. Registros de episódios sísmicos na parte superior da formação Rio do Rasto no Paraná, Brasil. In: SIMPÓSIO DE GEOLOGIA DO SUDESTE, 3., Rio de Janeiro, 1993. Atas. Rio de Janeiro, SBG. p. 271-275.

FLORENCE, G.; PACHECO, J.-1929- Carta geológica do Estado de Săo Paulo, Brasil, escala 1:2.000.000. Boletim da Comissăo Geográfica e Geologica de Estado de Sáo Paulo, v. 22. (Mapa anexo).

FOLK, R.L.-1974- Petrology of sedimentary rocks. Austin, Hemphill Publication Co. 159 p.

FOLK R.L.; PITTMAN, J.S.-1971- Length-slow calcedony: a new testament for vanished evaporites. Journal of Sedimentary Petrology, v. 41, n. 4, p. 1045-1508.

FRASER, G.S.-1989- Clastic Deposicional Sequences - Processes of evolution and principles of interpratation. Englewood Cliffs, Prentice Hall. 460 p.

FOURNIER, R.O.; CHRISTIANSEN, R.L.; HUTCHISON, R.A.; PIERCE, K.L. -1994- A Field-Trip Guide to Yellowstone National Park, Wyoming, Montana, and Idaho - Volcanic, Hydrotermal, and Glacial Activity in the Region. U.S. Geological Survey Bulletin, n. 2099, 46p.

FÚLFARO, V.J.-1970- Contribuição à geologia da região de Angatuba, Estado de São Paulo. Boletim. Divisåo de Geologia e Mineralogia. Departamento Nacional da Produçăo Mineral, v. 253, p. 1109.

FÚLFARO, V.J.-1972- The Paraná Basin Upper Permian and Lower Mesozoic stratigraphic succession. Anais da Academia Brasileira de Ciências, v. 44 (Suplemento), p. 147-148.

GAMA Jr., E.; BANDEIRA Jr., A.N.; FRANÇA, A.B.-1982- Distribuição espacial e temporal das unidades litoestratigráficas paleozóicas na parte central da Bacia do Paraná. Revista Brasileira de Geociências, v. 12 , n. 4 , p. 578-589.

GOMES, F.A.-1968- Fossas tectônicas do Brasil. Anais da Academia Brasileira de Ciencias, v. 40(Suplemento), p. 255-271.

GONZAGA DE CAMPOS, L.F. -1889- Secção Geológica. In: DERBY, O.A. (ed.) Relatório apresentado à Assembléia Provincial de Såo Paulo. São Paulo, Comissão Geogrâfica e Geológica da Província de São Paulo. p. 3-4.

GORDON Jr, M.-1947- Classificação das formações gondwânicas do Paraná, Santa Catarina e Rio Grande do Sul. Rio de Janeiro, Notas Preliminares e Estudos. Divisáo de Geologia e Mineralogia. Departamento Nacional da Produçăo Miñeral, v. 38, p. 1-20.

GUPTA, H.K.-1980- Geothermal resources: an energy alternative. Amsterdam, Elsevier. 227 p.

HACHIRO, J.-1991- Litotipos, associaçães faciológicas e sistemas deposicionais da Formaçåo Irati no Estado de Săo Paulo. São Paulo, 175p. (Dissertação de Mestrado - Instituto de Geociências- 
USP).

HACHIRO, J.; COIMBRA, A.M.-1992- Tectônica e paleogeografia da Formação Irati no nordeste da Bacia do Paraná. In: Boletim /G-USP. Publicaçăo especial. v. 12, p. 51-52 / Apresentado nas Jornadas Científicas,2, São Paulo.

HACHIRO, J.; COIMBRA, A.M.; MATOS, S.L.F. DE -1993- O caráter cronoestratigráfico da unidade Irati. In: SIMPÓSIO SOBRE A CRONOESTRATIGRAFIA DA BACIA DO PARANÁ, 1., Rio Claro, 1993. Resumos. Rio Claro, UNESP/SBG. p.72-74.

HUNTER, R.E. -1977- Basic types of stratification in small eolian dunes. Sedimentology, v.24, p. 361388.

JAMES, N.P.-1984- Shallowing-upward sequences in carbonates. In: WALKER, R.G. (ed.) Facies Models. Toronto, Geological Association of Canada. p. 213-228. (Geoscience Canada Reprint Series, 1).

JONES, B.; DESROCHERS, A.-1992- Shallow platform carbonates. In: WALKER, R.G.; JAMES, N.P. (ed.) Facies Models - Response to sea level change. Toronto, Geological Association of Canada. p. 277-302.

KENDALL, A.C.-1984- Evaporites. In: WALKER, R.G. (ed.) Facies Mode/s. Toronto, Geological Association of Canada. p. 259-296. (Geoscience Canada Reprint Series,1).

KOCUREK, G.-1981. Significance of interdune and bounding surfaces in aeolian dune sands. Sedimentology, v. 28, p. 753-780.

LANDIM, P.M.B.-1970- O Grupo Passa Dois (P) na Bacia do Rio Corumbataí (SP). Rio de Janeiro. Boletim. Divisão de Geologia e Mineralogia. Departamento Nacional da Produçăo Mineral, v. 252, p. 1-103.

LASNICKA, P.-1988- Breccias and coarse fragmentites. New York, Elsevier. 832p.

LAVINA, E.L.-1991- Geologia sedimentar e paleogeografia do Neopermiano e Eotriássico (intervalo Kazaniano-Scythiano) da Bacia do Paraná. Porto Alegre, 450p. (Tese de Doutoramento Universidade Federal do Rio Grande do Sul).

LEINZ,V.-1949- Contribuição à geologia dos derrames basálticos do sul do Brasil. Boletim da Faculdade de Filosofia, Letras e Ciencias Humanas da Universidade de Sáo Paulo. Serrie Geologia. v. 103, n. 5, p. 61-76.

MARLER, G.D.-1964- Effects of the Heggen Lake Earthquake of August 17, 1959, on the hot springs of Firehole Geyser Basin, Yellowstone National Park. U.S. Geological Survey Professinal Paper, v. 435-Q, p.185-197.

MARLER, G.D.; WHITE, D.E.-1975- Sismic geyser and its bearing on the origin and evulution of geyser and hot springs of Yellowstone National Park. Geological Society of America Bulletin, $v$. 86, p. $749-759$.

MacDONALD, G.A.-1972- Volcanoes. Englewood Cliffs, Prentince-hall. 510p.

MELO E SOUSA, S.H.-1985- Fácies sedimentares das formaçסes Estrada Nova e Corumbatal no Estado de Săo Paulo. São Paulo, 142p. (Dissertação de Mestrado - Instituto de GeociênciasUSP).

MEZZALIRA, S.-1989- Os fósseis do Estado de São Paulo 2ed. São Paulo, Instituto Geológico. 142p. (Série Pesquisa)

MIALL, A.D.-1992- Principles of Sedimentary Basin Analysis. New York, Springer-Verlag. 490p. 
MILANI, E.J.; FRANÇA, A.B.; SCHNEIDER, R.L.-1994- Bacia do Paraná. Boletim de Geociencias da Petrobrás. v. 8, n. 1, p. 69-82.

MILLOT, G.-1970- Geology of clays. New York, Springer-Verlag. 347p.

MIDDLETON, G.V.-1973- Johannes Walther's law of correlation of fácies. Geological Society of America Bulletin, v. 84 p. $979-988$.

MORAES REGO, L.F.-1930- A geologia do petróleo no Estado de São Paulo. Rio de Janeiro. Boletim. Senviço Geológico e Mineralogico do Brasil. v. 46, p. 1-110.

MUSSA, D.; COIMBRA, A.M.-1984- Método đe estudo tafonômico aplicado a lignispécimes permianos da Bacia do Paraná. Anais da Academia Brasileira de Ciencias, v. 56, n. 1, p. 85-101.

NORTHFLEET, A.A.; MEDEIROS, R.A.; MUHLMAN, H.-1969- Reavaliação dos dados geológicos da Bacia do Paraná. Boletim Técnico da Petrobrás, v. 12, n. 3, p. 291-346.

OJEDA Y OJEDA, H.A.-1988- Curso de Sismoestratigrafia. Rio de Janeiro, Petrobrás. 350p.

OLIVEIRA, F.P.-1889- Reconhecimento Geológico do Vale do Paranapanema. Boletim da Comissåo Geográfica e Geologica do Estado de São Paulo, v. 2, p. 27-55.

OLIVEIRA, E.P.-1930- Nota sobre os arenitos de Botucatu e Pirambóia. In; MORAES REGO, L.F. Geologia do petróleo no Estado de São Paulo. Boletim. Serviço Geológico e Mineralógico do Brasil. v. 46, p.50-54.

OPPENHEIM, V.-1935- Petroleum Geology of Gondwana Rocks of Southern Brazil. American Association of Petroleum Geologists Bulletin, v. 19, n. 12, p. 1725-1805.

PACHECO, J.-1927- Relatório elucidativo do esboço geológico da região entre o meridiano $4^{\circ}$, Rio Itararé e os paralelos $23^{\circ} 23^{\prime}$ e $24^{\circ} 38^{\prime}$. In: COMISSÃO GEOGRÁFICA E GEOLÓGICA' DO ESTADO DE SÃO PAULO. Exploraçăo da regiăo compreendida pelas folhas topograficas Sorocaba, Itapetininga, Bury, Faxina, Itaporanga, Sete Barras, Capåo Bonito, Ribeirão Branco e Itararé. São Paulo, Comissão Geográfica e Geológica do Estado de São Paulo. 12p.

PETRI, S.; COIMBRA, A.M.-1982- Estruturas sedimentares das formaçães Irati e Estrada Nova (Permiano) e sua contribuição para a elucidação dos seus paleoambientes geradores, Brasil. In: CONGRESO LATINO AMERICANO DE GEOLOGIA, 5., Buenos Aires, 1982. Actas. Buenos Aires. v.2, p.353-371.

PETRI, S.; FULFARO, J.V. -1983- Geologia do Brasil. São Paulo, T.A. Queiroz-EDUSP. 632p.

PETRI, S.; COIMBRA, A.M.; AMARAL, G.; PONÇANO, W.L.-1986- Guia de nomenclatura estratigráfica. Revista Brasileira de Geociências, v. 16, n. 4, p. 376-415.

PETTIJOHN, F.J.-1975- Sedimentary Rocks. New York, Harper \& Row. 628p.

PETTIJOHN, F.J.; POTTER, P.E.; SIEVER, R.-1987- Sand and Sandstone. Berlin, Springer-Verlag. $617 p$.

PINCUS, H.J.-1953- The analysis of aggregates of orientation data in the earth science. Joumal of Geology, v. 61, n. 6, p. 484-499.

PINCUS, H.J.-1956- Some vector and arithmetic operations on two dimentional orientation variates, with application to geological data. Journal of Geology, v. 64, n. 6, p. 533-558.

PONÇANO, W.C.; ALMEIDA, F.F.M. DE; CARNEIRO, C.D.R.; BISTRICHI, C.A.; PIRES Neto, A.G.; ALMEIDA, M.A. DE -1981- Mapa Geomorfológico do Estado de São Paulo. In: IPT, Mapa Geomorfologico do Estado de Săo Paulo, escala 1:1.000.000. São Paulo. IPT. v. 2 (Monografia 으 5). 
POTTER, P. E. ; PETTIJOHN, F.J. -1977- Palaeocurrents and Basin Analysis. Berlin, Springer-Verlag. $425 p$.

POTTER, P.E.; SHIMP, N.F.; WITTERS, J.-1963- Trace elementes in marine and fresh watwer argillaceous sediments. Geochimica et Cosmochimica Acta, v. 27, p. 669-694.

PRATT, B.R.; JAMES, N.P.; COWAN, C.A.-1992- Peritidal carbonates. In: WALKER, R.G.; JAMES, N.P. (ed.) Facies Models - Response to sea level change. Toronto, Geological Association of Canada. p. 303-322.

RAGONHA, E.W.-1984- Taxionomia de dentes e espinhos isolados de Xenacanthodi (Chondrichthyes, Elasmobranchii) da Formaçăo Corumbatal. Consideraçס̃es cronológicas e paleoambientais. São Paulo, 166p. (Tese de Doutoramento - Instituto de Geociências-USP).

RAGONHA, E.W.-1989- Placas dentárias de dipnoi no Grupo Passa Dois (P-Tr) da Bacia do Paraná. Apreciações ambientais, climáticas, cronológicas e estratigráficas. In: CONGRESSO BRASILEIRO DE PALEONTOLOGIA, 11., Curitiba, 1989. Anais. Curitiba, SBP. v. 1, p. 195-206.

RAMOS, A.N.; FORMOSO, M.L.L.-1975- Argilominerais das rochas sedimentares da Bacia do Paraná. Rio de Janeiro. Petrobrás. Ciéncia Técnica Petroleo, Seção Exploração de Petróleo, n. 9, p. 1-47.

READING, H.G.-1986- Facies. In: READING, H.G. ed. Sedimentary Environments and Facies. 2ed. Oxford, Blackwell. p.4-19.

READING, H.G.-1986- ed. Sedimentary Environments and Facies. 2ed. Oxford, Blackwell. 615 p.

REISON, G.E.-1984- Barrier Island and Associated Strand-Plain Systems. In: WALKER, R.G. (ed.) Facies Models. Toronto, Geological Association of Canada. p. 119-140. (Geoscience Canada Reprint Series, 1)

RICCOMINI, C.; GIMENEZ FILHO, A.; ALMEIDA, F.F.M. DE -1984- Consideraçães sobre a estratigrafia do Permo-Triássico na região da Serra do Cadeado, Paraná. In: CONGRESSO BRASILEIRO DE GEOLOGIA, 23, Rio de Janeiro, 1984. Anais. Rio de Janeiro, SBG. v.3, p.1351-1361.

RICCOMINI, C.; CHAMANI, M.A.C.; AGENA, S.S.; FAMBRINI,G.L.; FAIRCHILD, T.R.; COIMBRA A.M.-1992- Earthquake induced liquefaction features in the Corumbatai formation (Permian, Paraná Basin, Brazil and the dynamics of Gondwana). Anais da Academia Brasileira de Ciências, v. 64, p. 210.

ROCHA CAMPOS, A.C.; SIMÕES, M.G.M.; MATOS, S.L.F. DE -1990- Uma nova assembléia de bivalves silicificados, na parte superior da Formação Teresina (Neopermiano), Estado de São Paulo. in: CONGRESSO BRASILEIRO DE GEOLOGIA, 36., Natal, 1990. Boletim de resumos. Natal, SBG. p. 30 .

RODRIGUES, R.; QUADROS, L.P.-1976- Mineralogia das argilas e teor de boro das formaçães paleozóicas da Bacia do Paraná. In: CONGRESSO BRASILEIRO DE GEOLOGIA, 29, Ouro Preto,-1976. Anais. Ouro Preto, SBG. v. 2, p. 351-380.

ROHN, R.-1995- Evoluçăo ambiental da Bacia do Paraná durante o Neopermiano no leste de Santa Catarina e do Paraná. São Paulo, 175p. (Tese de Doutoramento - Instituto de Geociências USP).

ROHN, R.; LAVINA, E.L.-1993- Cronoestratigrafia do Grupo Passa Dois. In: SIMPÓsIO SOBRE CRONOESTRATIGRAFIA DA BACIA DO PARANÁ, 1. Rio Claro, 1993. Resumos. Rio Claro, UNESP. p.83.

RÖSLER, O; COIMBRA, A.M.; ROHN, R.-1985- Paleontologia do topo da Formação Corumbataí na seção da rodovia Castelo Branco, Estado de São Paulo. Anais da Academia Brasileira de Ciências, v. 57, n. 1, p. 119. 
RONCARATI, H.-1971- Projeto Arenito Asfáltico. Ponta Grossa, Petrobrás. 36p. (Relatório DESUL no 408).

ROUCHY, J.M.-1979- Les séquences évaporitiques du miocène terminal de Sicile et d'Espagne Méridionnale. In: Chambre syndicale de la recherche et de la production du pétrole et du gaz naturel (ed.) Dépóts évaporitiques: illustration et interprétation de quelques sequences. Paris, Technip. p. 33-40.

SALVANY, J.M.; MUÑOZ, A.; PEREZZ, A.-1994- Nonmarine Evaporitic Sedimentation and Associated Diagenetic Processes of the Southwestern Margin of the Ebro Basin (Lower Miocene), Spain. Journal of Sedimentary Research. Section A, v. 64, n. 2, p. 190-203.

SANFORD, R.M.; LANGE, F.W.-1960- Basin-study approach to oil evaluation of Paraná Miogeosyncline, South Brazil. American Association of Petroleum Geologists Bulletin, v. 44, n. 8 , p. 1316-1370.

SCHNEIDER, R.L.; MUHLMANN, H.; TOMMASI, E.; MEDEIROS, R.A.; NOGUEIRA, A.A.; DAEMON, R.F.-1974- Revisão estratigráfica da Bacia do Paraná. In: CONGRESSO BRASILEIRO DE GEOLOGIA, 28., Porto Alegre, 1974. Anais. Porto Alegre, SBG. v. 1, p. 41-65.

SCHOBENHAUS, S.C; CAMPOS,D.A.; DERZE, G.R.; ASMUS, H.E.-1984- Geologia do Brasil: texto expicativo do mapa geo,lógico do Brasil e da área oceânica adjacente, incluindo depósitos minerais, escala 1:2.500.000. Brasília, Departamento Nacional da Produção Mineral. 501p.

SCHEREIBER, B.C.-1986- Arid Shorelines and Evaporites. In: READING, H.G. (ed.) Sedimentary Environments and Facies. 2ed. Oxford, Blackwell. p. 189-228.

SELLEY, R.C.-1985- Ancient Sedimentary Environments and their subsurface diagnosis. 3ed. London, Chapman \& Hall. 317p.

SELLWOOD, B.W.-1986. Shallow-marine Carbonate Enviromenments. In: READING, H.G. ed. Sedimentary Environments and Facies. 2ed. Oxford, Blackwell. p.283-342.

SIBSON, R.H.; MOORE J.MCM.; RANKIN, A.H. -1975- Seismic pumping - a hydrothermal fluid transport mechanism. Journal of the Geological Society of London. v. 131, p.653-659.

SIBSON, R.H. -1981- Fluid flow accompanying faulting: field evidences and models. In: SIMPSON, D.W. \& RICHARDS, P.G. (eds.) Earthquake prediction: an international review. Washington, American Geophisical Union. 686p. (Maurice Edwing Series no 0 ).

SIMS, J.D.-1975- Determining earthquake recurrence intervals from deposicional structures in young lacustrine sediments. Tectonophysics, v. 29, p. 146-156.

SINGER, A.-1984- The paleoclimatic interpretation of clay minerals in sediments-a review. Earth Science Reviews, v. 21, p. 251-293.

SLOSS, L.L.-1963- Sequences in the cratonic interior of North America. Bulletin of Geological Society of America, v. 74, p. 93-114.

SOARES, P.C.-1972- Estruturas estromatolíticas do Permiano no Estado de São Paulo. In: CONGRESSO BRASILEIRO DE GEOLOGIA, 26., Belém. Resumo das comunicaçőes. Belém, SBG. p. 167. 249

SOARES, P.C.-1973- O Mesozóico gondwânico no Estado de Sáo Paulo. Rio Claro. 260p. (Tese de Doutoramento - Departamento de Geologia e Mineralogia da Faculdade de Ciências e Letras UNESP).

SOARES, P.C.-1974- Elementos estruturais da parte nordeste da Bacia do Paraná: classificação e gênese. In: CONGRESSO BRASILEIRO DE GEOLOGIA, 28., Porto Alegre, 1974. Anais. Porto Alegre, SBG. v.4, p.107-121. 
SOARES, P.C.; LANDIM, P.M.B.; FÚLFARO, V.J.-1974- Avatiação preliminar da evolução geotectônica das bacias intracratônicas brasileiras. In: CONGRESSO BRASILEIRO DE GEOLOGIA, 28., Porto Alegre, 1974. Anais. Porto Alegre, SBG. v.4, p.61-83.

SOLMS-LAUBACH, H.G. zu -1913- Tietea singularis, ein neuer Fossiler Pteridinenstyamm aus Brasilien. Zeitschrift Botanisches, v. 5, n. 9, p. 673-700.

SOUZA, A.; SINELLI, O.; GONSALVES, N.M.M.-1971- Nova ocorrência fossilífera na Formação Botucatu. In: CONGRESSO BRASILEIRO DE GEOLOGIA, 25., São Paulo. 1971. Anais. São Paulo, SBG. v. 2, p. 281-295.

SUGUIO. K; SALATI, E.; BARCELOS, J.H.-1974- Calcários oolíticos de Taguaí (SP) e seu possível significado paleoambiental na deposição da Formação Estrada Nova. Revista Brasileira de Geociencias, v. 4, p. 142-166.

THOMAZ FILHO, A.-1972- Controle estratigráfico e a influência de movimentaçסes estruturais na ocorrência de óleo asfáltico no Arenito Pirambóia - Área Guareí-Carlota Prenz, São Paulo. Ponta Grossa, Petrobrás (Relatório DESUL n으 422).

TSUNEISHI, Y.; NAKAMURA, K. -1970- Faulting Associate with Matsushiro Swarm Earthquakes. Bulletin of the Earthquake Research Institute. University of Tokyo. v. 48, n. 1, p. $29-52$.

TUCKER, M. E.-1981- Sedimentay Petrology: an introduction. Oxford, Blackweils. 252p.

TUCKER, M. E.-1989- The field description of sedimentary rocks. New York, John Wiley \& Sons. $113 p$.

VIEIRA, A.J.-1973- Geologia do centro e nordeste do Paraná e centro-sul de São Paulo. In: CONGRESSO BRASILEIRO DE GEOLOGIA, 27., Aracaju, 1973. Anais. Aracaju, SBG. v.3, p.259-277.

VISHER, G.S.-1965- Use of vertical profile in environmental reconstruction. American Association of Petroleum Geologists Bulletin, v. 49, n. 1, p. 41-61.

WALKER, R.G.-1992- Facies, facies models and modern stratigraphic concepts. In: WALKER, R.G.; JAMES, N.P. (ed.) Facies Models - Response to sea level change. Toronto, Geological Association of Canada. p. 1-14.

WALKER, R.G.; JAMES, N.P. -1992- (ed.) Facies Models - Response to sea level change. Toronto, Geological Association of Canada. $454 \mathrm{p}$.

WALTER, M.R.-1976- Geyserites of Yellowstone National Park: an example of abiogenic "stromatolites". In: WALTER, M.R. (ed.) Stromatolites. Amsterdam, Elsevier. p.87-112.

WARING, G.A. -1965- Thermal Springs of the United State and other Countries of the World - A Summaring. U.S. Geological Survey Bulletin, n. 492. 383p.

WASHBURNE, C.-1929- State of São Paulo, Brazil. American Association of Petroleum Geologists Bulletin, v. 13, n. 9, p. 1215-1217.

WASHBURNE, C.-1930- Petroleum geology of the State of São Paulo, Brazil. Boletim da Comisão Geográfica e Geológica do Estado de Săo Paulo. v. 22, p. 1-282.

WHITE, D.E.-1967- Some principles of geyser activity, mainly from Steambost Springs, Nevada. American Journal of Science, v. 265, n. 8, p. 641-684.

WHITE, D.E.-1991- Whistle, a nearly dorment geyser in Upper Geyser Basin, Yellowstone National Park, Wyoming: the first geyser to be studied by research brilling.U.S. Geological Survey Bulletin, n. 1967, 13p. 
WHITE, D.E. -1992- The Beowawe geysers, Nevada, before geothermal developmente. U.S. Geological Survey Bulletin, n. 1998, 25p.

WHITE, I.C.-1908- Final Report. Rio de Janeiro, Comissão de Estudos das Minas de Carvão de Pedra do Brasil. 337.

WILSON, M.D.; PITTMAN, E.D.-1977- Autigenic clays in sandstones. Recognition and influence on reservoir properties and paleoenvironmental analysis. Journal of Sedimentary Petrology, v. 47, p. 3-31.

WOODS P.J.;BROWN, R.G.-1975- Carbonate sedimentation in an arid zone tidal flat, Milemah embayment, Shark bay, western Australia. In: GINSBURG, R.N. (ed.) Tidal Deposits. Berlim, Springer-Verlag. p. 223-232.

ZALÁN, P.V.; WOLFF, S.; CONCEIÇ̃̃O, J.C.J.; MARQUES, A.; ASTOLFI, M.A.M.; VIEIRA, I.S.; APPI, V.T.; ZANNOTO, O.A. -1990- Bacia do Paraná. In: GABAGLIA, G.P.R.; MILANI. E.J. (coord.) Origem e evoluçăo de bacias sedimentares. Rio de Janeiro, Petrobrás. p. 135-168. 
12. FOTOS 
PRANCHA 1

Foto 1: Bioesparito e micrito fossilifero do topo da Formação Teresina. As carapaças são de ostracodes. Amostra de corte da Rodovia Castelo Branco ( SP 280), km 166,5.

Foto 2: Interlaminação entre bioesparito composto por carapaças de ostracodes e micrito com fragmentos de conchas, ambos apresentando grãos de quartzo. Rodovia Castelo Branco (SP 280), km 166,5.

Foto 3: $\quad$ Bioesparito composto por carapaças de ostracodes.

Foto 4: Microbialito da Formação Teresina com lâminas deformadas envolvendo concreções de silex. Pedreira Velha, Município de Taguaí.

Foto 5: Microbialito da Formação Teresina com lâminas deformadas e rompidas junto a concreções de sílex, possivelmente nódulos salinos substituídos. Rodovia Castelo Branco (SP 280) km 165. 


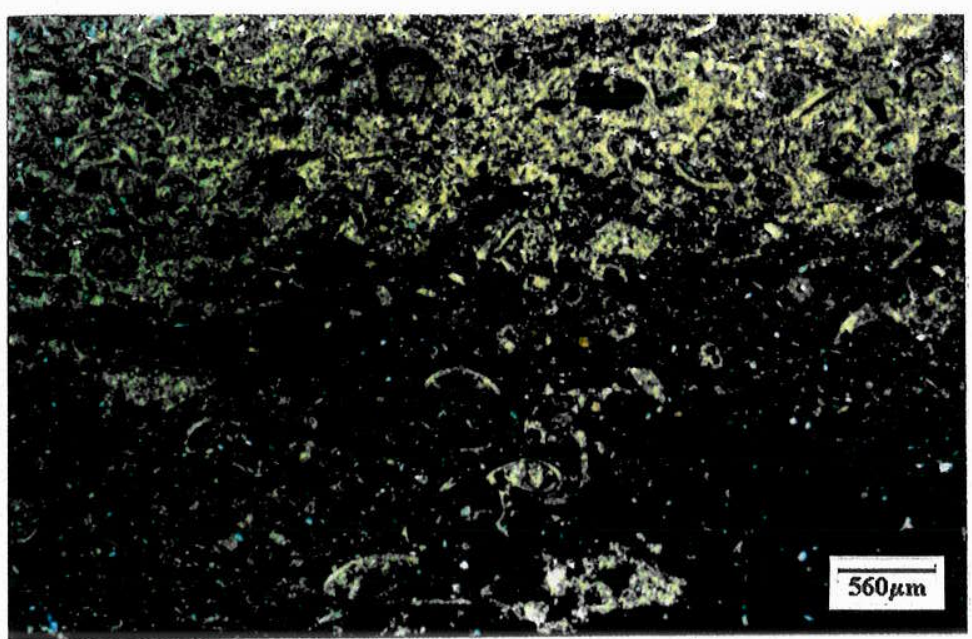

1

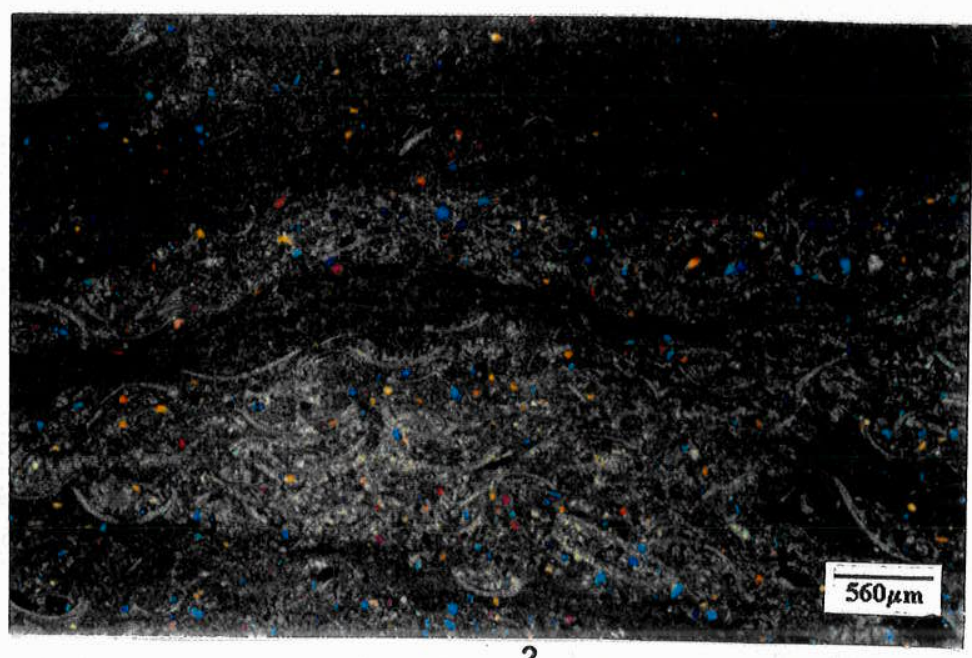

2

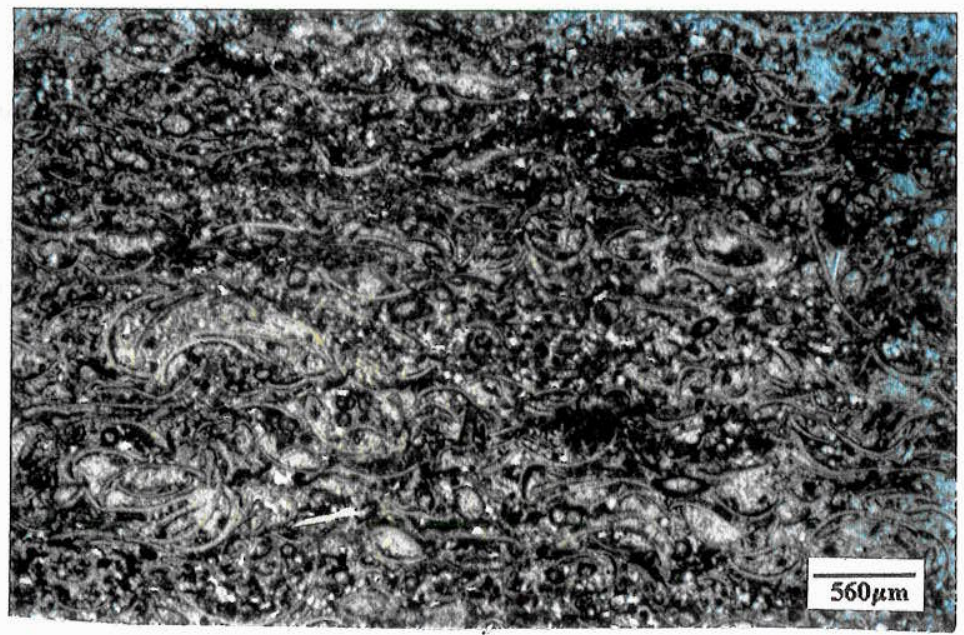

3
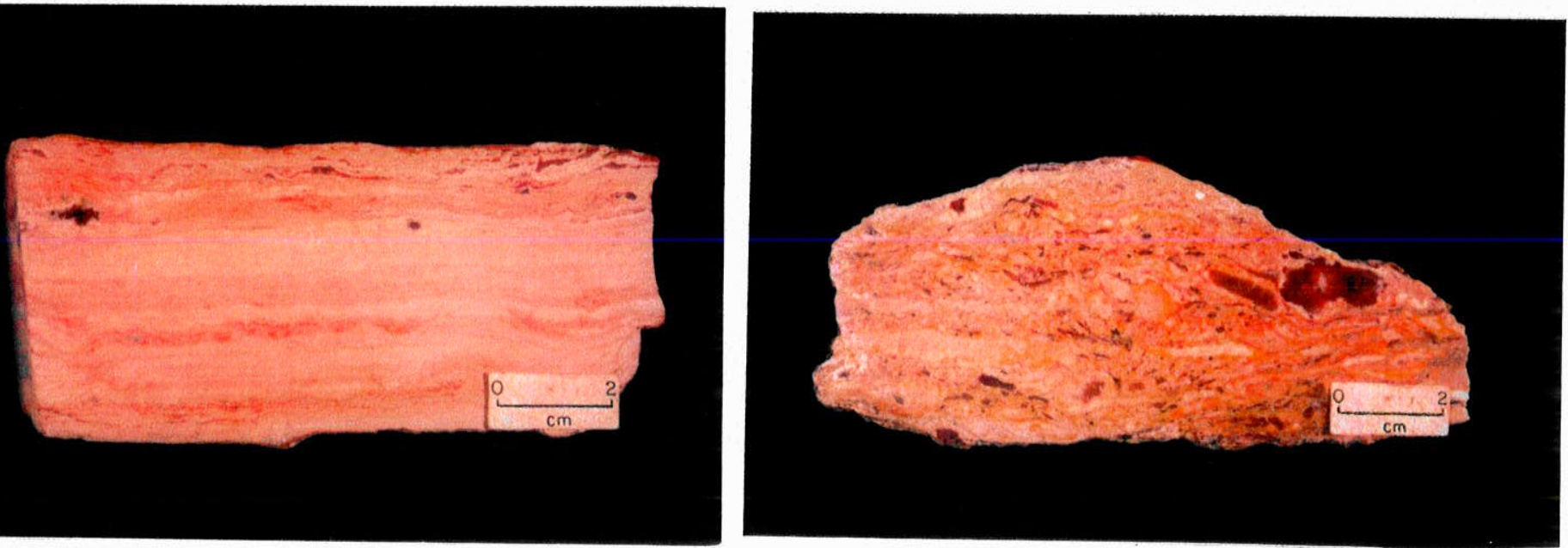
PRANCHA 2 Camada constituída por concreções de silex com textura denominada péde-moleque, na porção superior da Formação Teresina, interpretada como possivel depósito de gipsita nodular, substituída por sílica. Rodovia Castelo Branco (SP 280) km 168.

Foto 6: $\quad$ Afloramento da camada (na altura do martelo).

Foto 7: $\quad$ Detalhe do afloramento da camada.

Foto 8: $\quad$ Superfície do topo da camada onde observa-se a superfície lisa dos nódulos.

Foto 9: $\quad$ Fotomicrografia. As concreções estão revestidas por cimento carbonático e espaços entre concreções preenchidos por sílica fibrorradiada.

Foto 10: $\quad$ Dique clástico silicificado cortando camada de pelito e afetando camada com textura pé-de-moleque. Rodovia Castelo Branco (SP 280) km 168. 


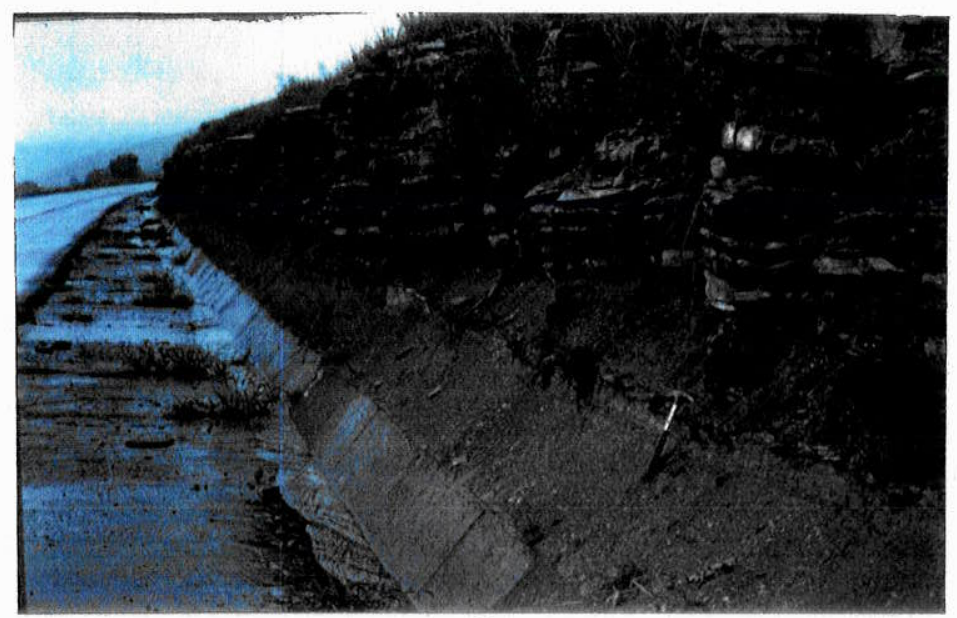

6
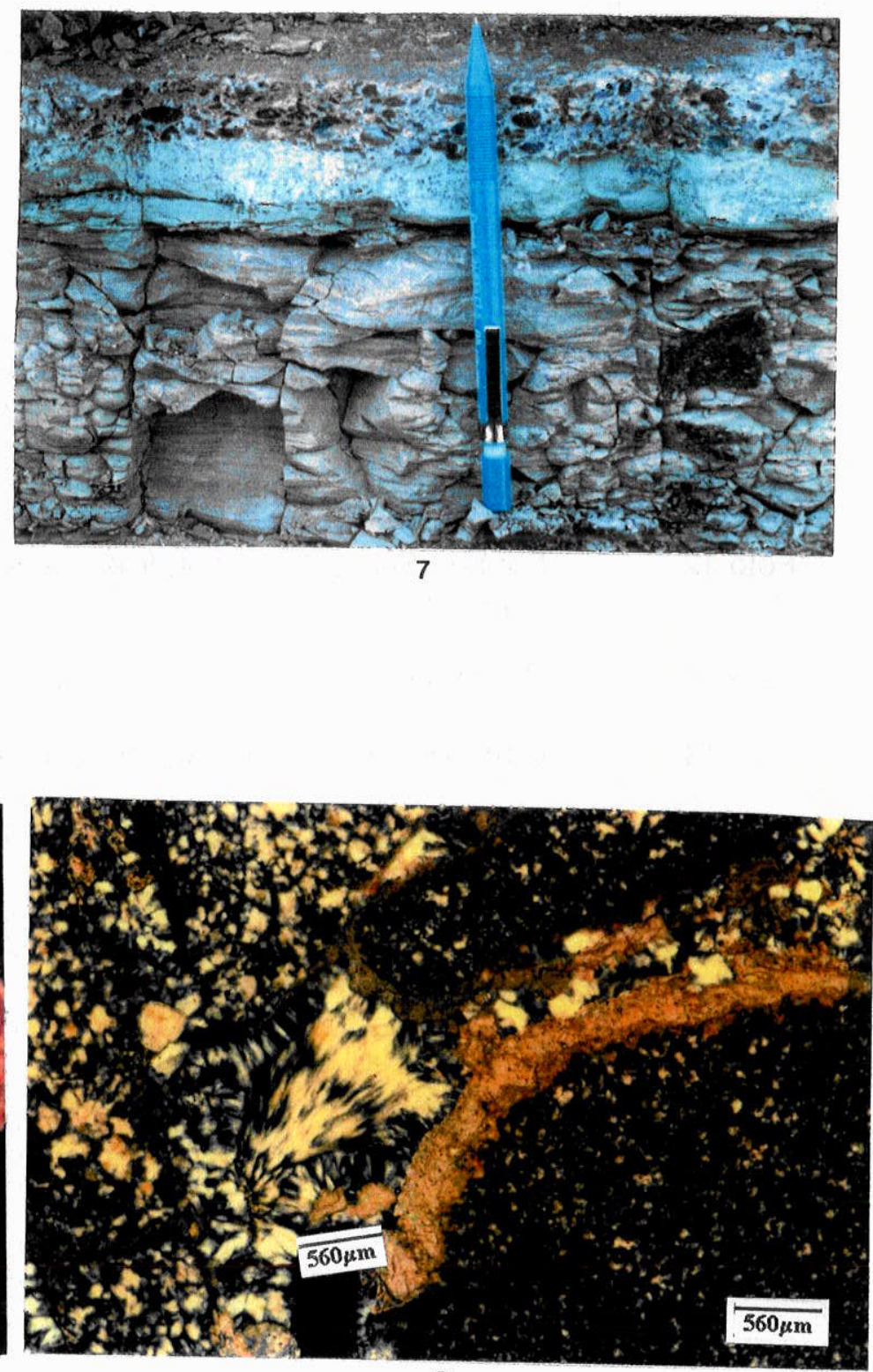

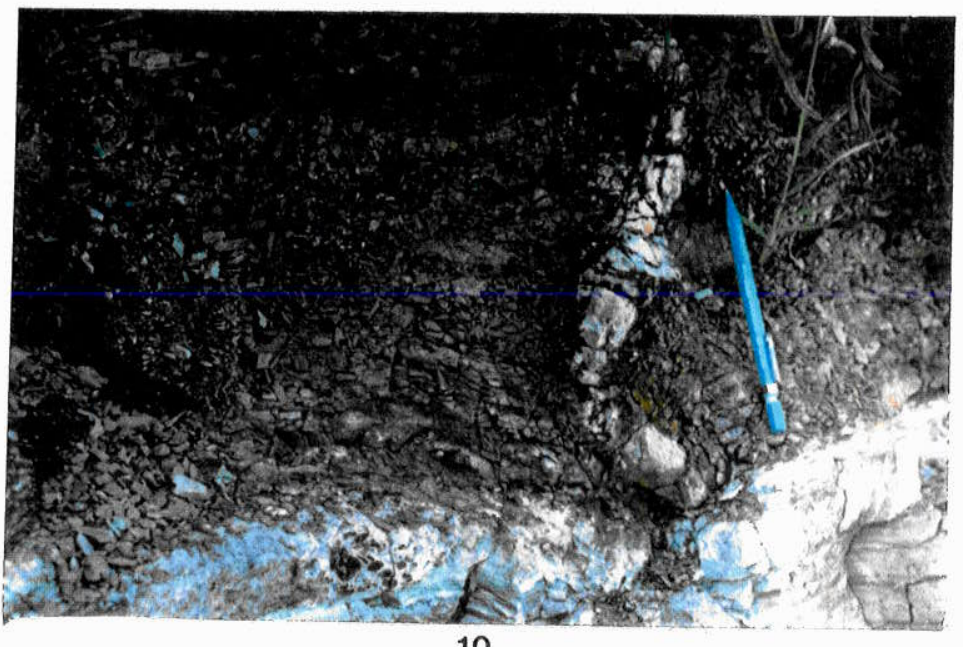


PRANCHA 3 Exemplos de formas dos corpos silicosos que ocorrem a $10 \mathrm{~km}$ a oeste de Anhembi, próximo ao vale do ribeirão do Retiro, SP.

Foto 11: Forma cônica, rompida, mostrando cilindro central com textura vesicular.

Foto 12: $\quad$ Forma cônica com cilindros de textura vesicular na lateral e na parte superior.

Foto 13: $\quad$ Corpo partido, mostrando sua parte interna oca com forma de abóboda.

Foto 14: $\quad$ Corte transversal de fragmento, com aspecto maçiço.

Foto 15: $\quad$ Fotomicrografia de seção delgada da amostra anterior. 


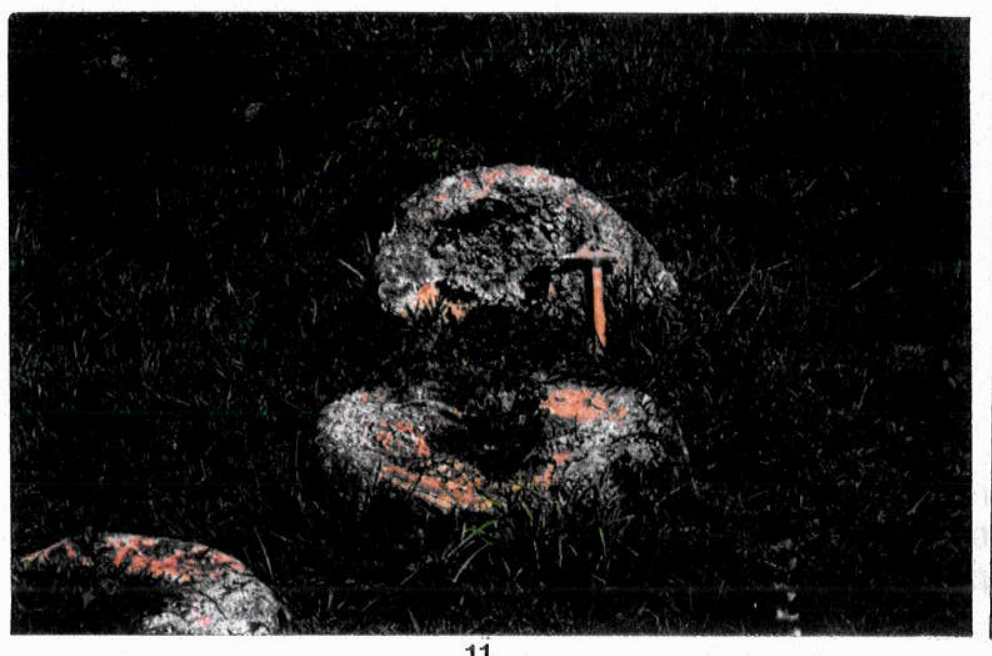

11

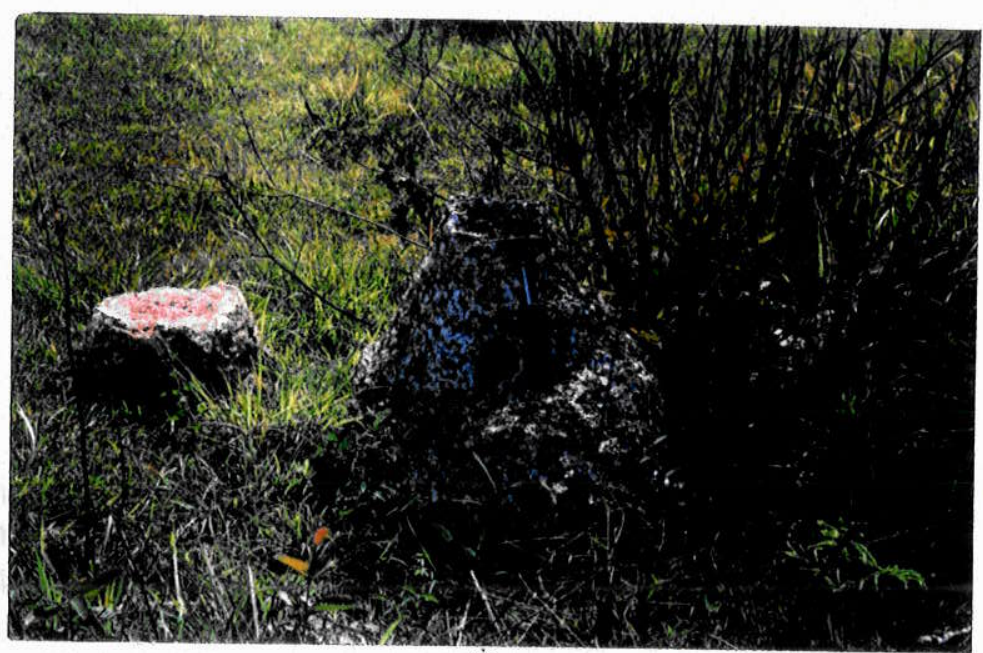

12

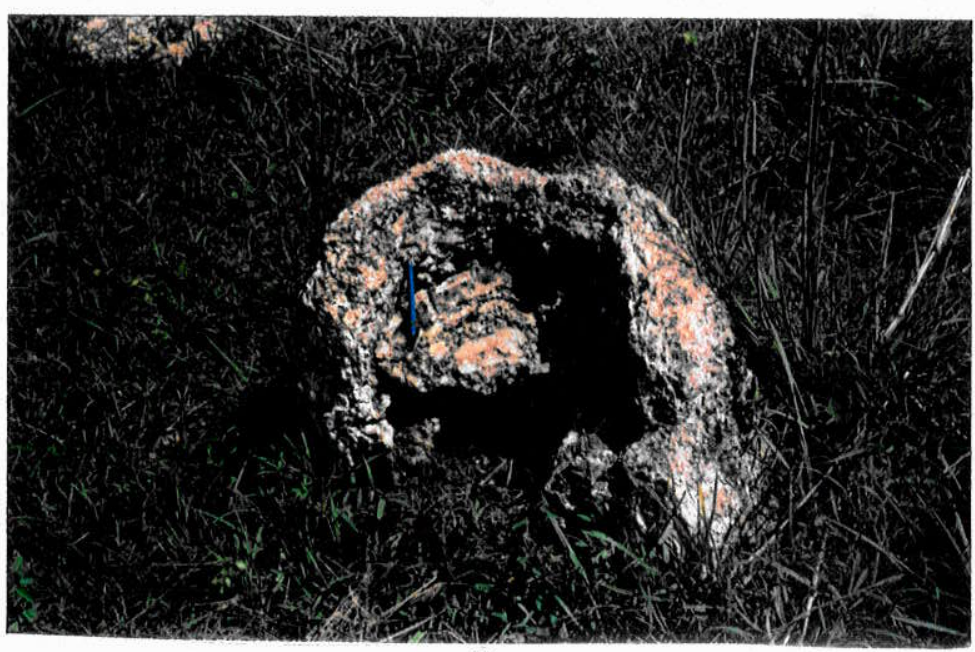

13

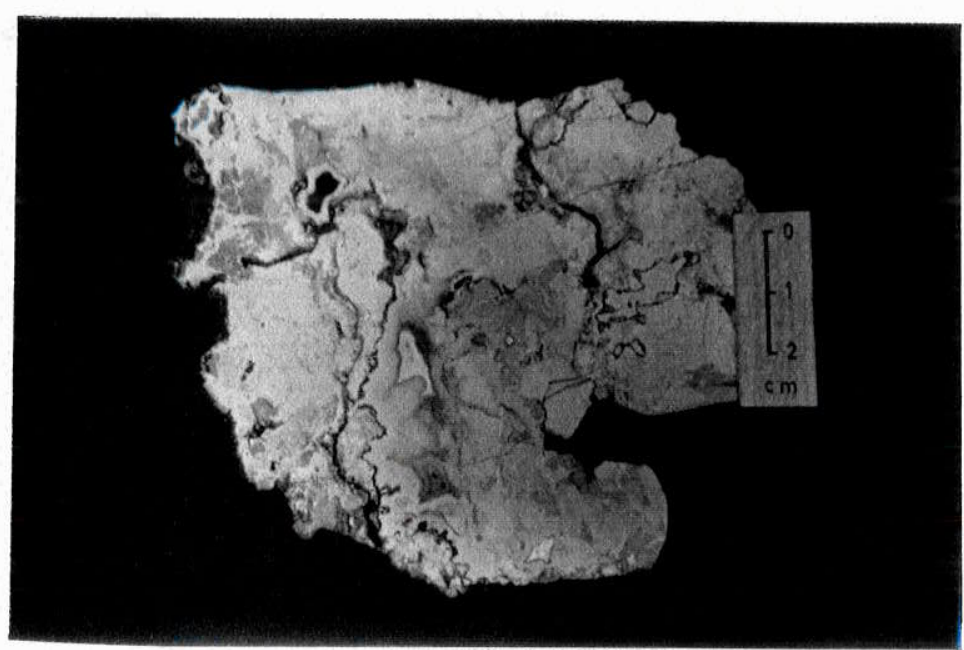

14

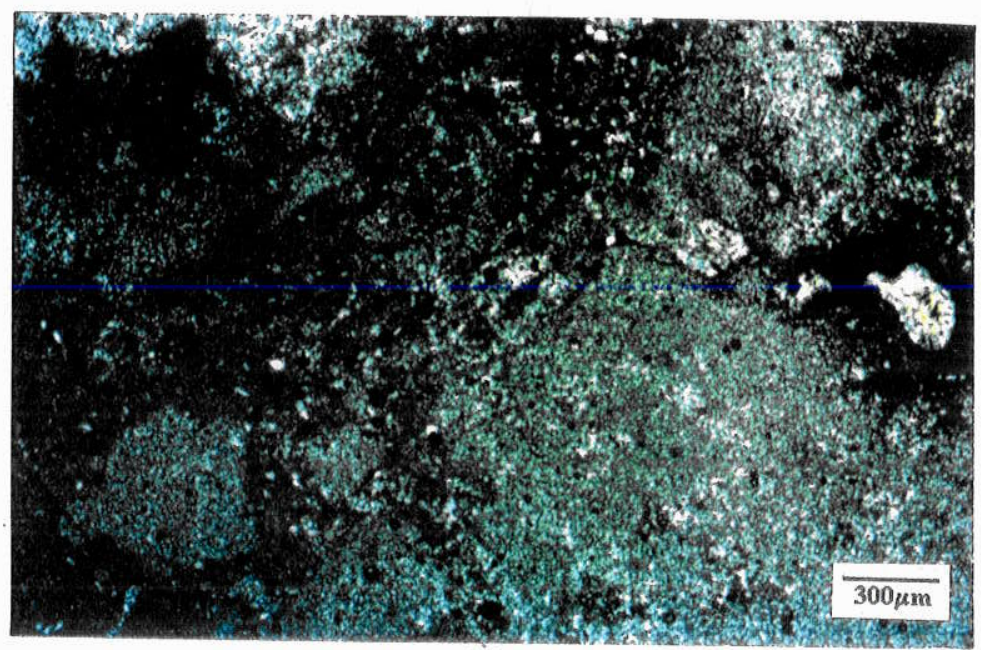


PRANCHA 4

Foto 16: $\quad$ Seção transversal do caule de psaronideo da Formação Teresina, com os vasos transportadores de fluídos em forma de "C". Rodovia Castelo Branco (SP 280) km 165, afloramento da pista sentido capital-interior.

Foto 17: $\quad$ Seção longitudinal do mesmo espécime da foto anterior, mostrando também vasos transportadores de fluídos.

Foto 18: $\quad$ Fragmentos de possíveis folhas de "licófitas", orientados em superfície de camada de calcilutito da Formação Teresina, Rodovia Castelo Branco (SP $280), \mathrm{km} \mathrm{168}$, sentido interior-capital. A orientação dos fragmentos foi atribuída à possivel posição de fossilização. 


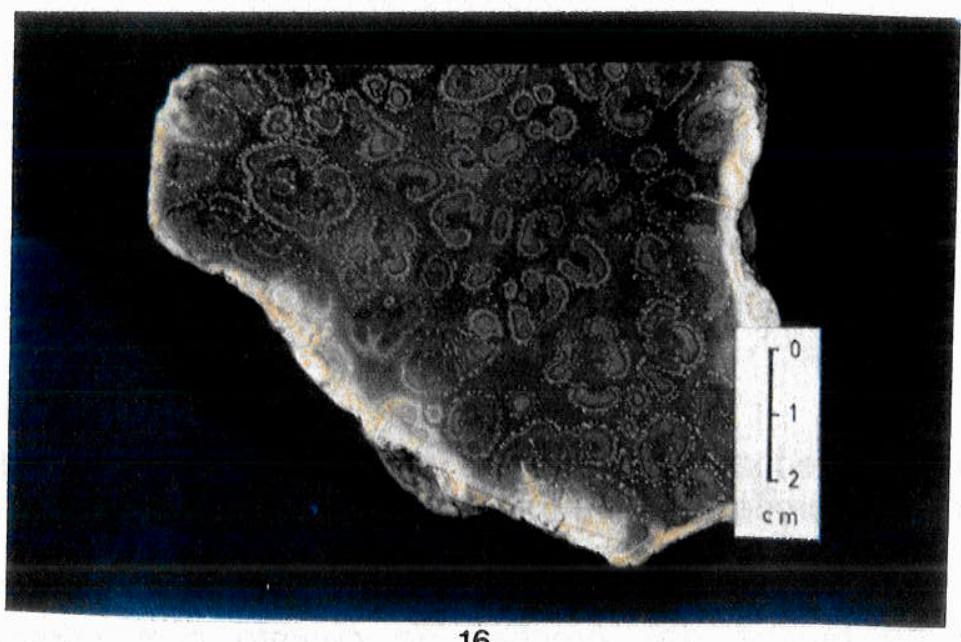

16
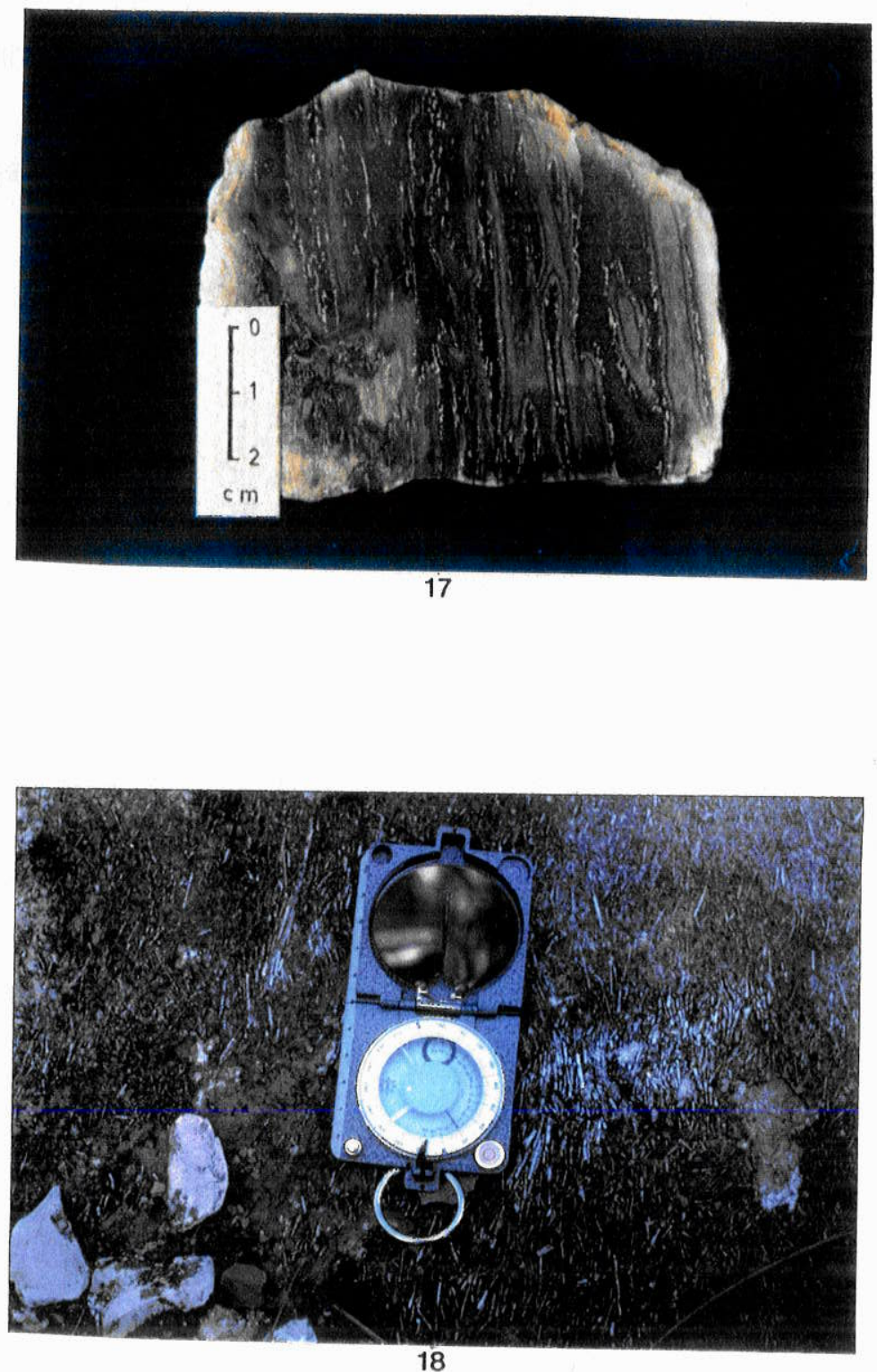

18 
PRANCHA 5

Foto 19: Camada de brecha das brechas do contato com intraclastos suborientados e porções com intraclastos em arranjo caótico (fácies $\mathrm{Bl}$ ). Rodovia Castelo Branco (SP 280), km 166,5.

Foto 20: $\quad$ Camada de brecha das brechas do contato com intraclastos suborientados, horizontalmente. Rodovia Castelo Branco (SP 280), km 166,5.

Foto 21: $\quad$ Detalhe de intraclastos destacando-se do topo de camada de calcilutito das brechas do contato. Rodovia Castelo Branco (SP 280), km 166,5.

Foto 22: $\quad$ Brecha com intraclastos angulosos e matriz composta por arenito pelítico. Rodovia Raposo Tavares (SP 270), km 199,5.

Foto 23: $\quad$ Arenito com intraclastos angulosos, em arranjo caótico, passando para arenito pelítico. Rodovia Raposo Tavares (SP 270), km 199,5. 

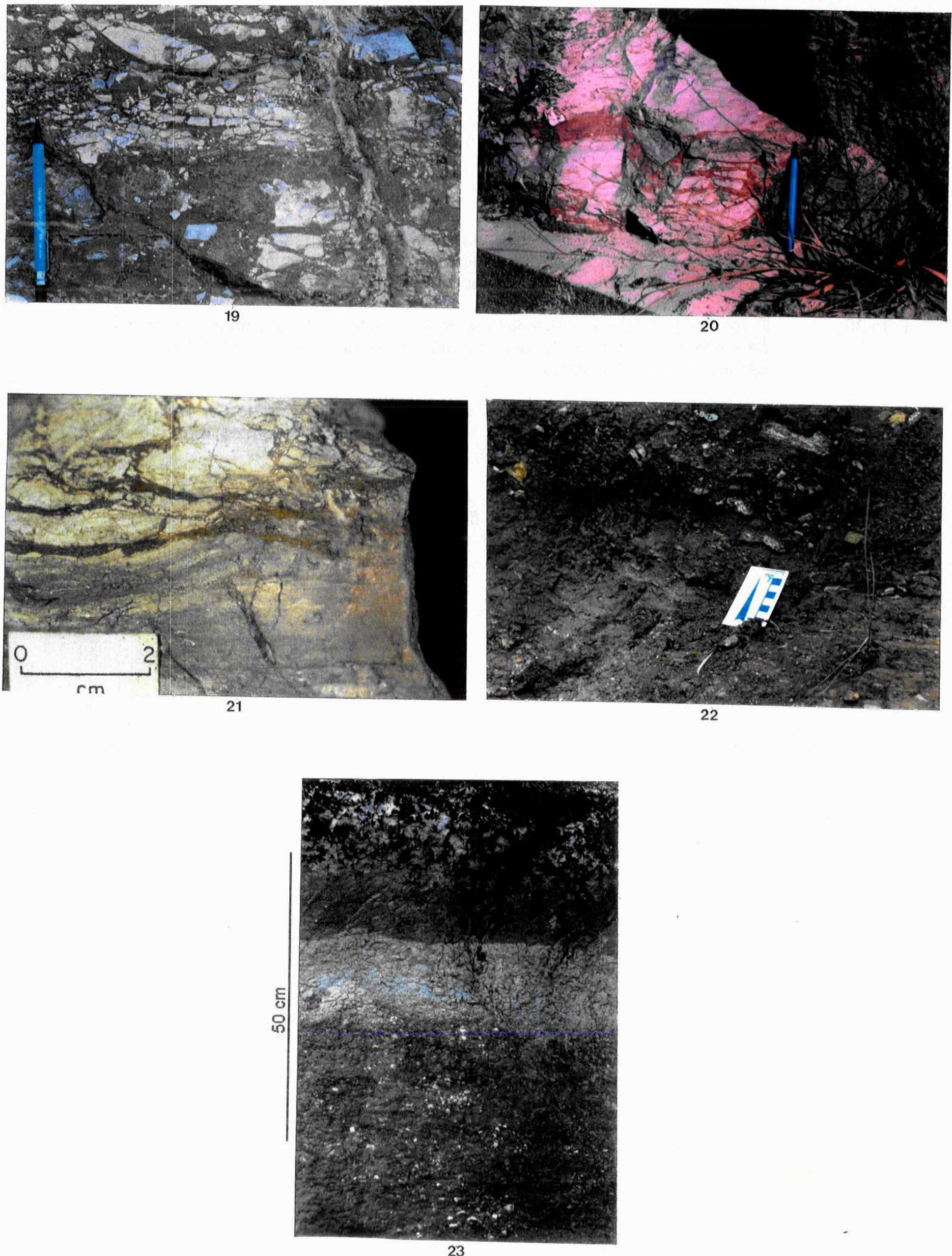
PRANCHA 6

Foto 24: Fotomicrografia de amostra da camada brechada, onde ocorre preenchimento por material pelítico avermelhado com cimentação carbonática. Rodovia Castelo Branco (SP 280) km 166,5.

Foto 25: $\quad$ Fotomicrografia de amostra das brechas do contato mostrando a presença de fósseis (carapaças de ostracodes) em intraclastos. Rodovia Castelo Branco (SP 280) km 166,5.

Foto 26: $\quad$ Camada basal da Formação Pirambóia, dividida internamente por estratos com superfícies de truncamento limitando corpos cuneiformes em corte. Rodovia Castelo Branco (SP 280), km 175

Foto 27: Detalhe de camada lenticular de arenito da Formação Pirambóia, interpretada como originada por fluxo de grãos. Rodovia SP 191, trecho São Pedro-Charqueada. 


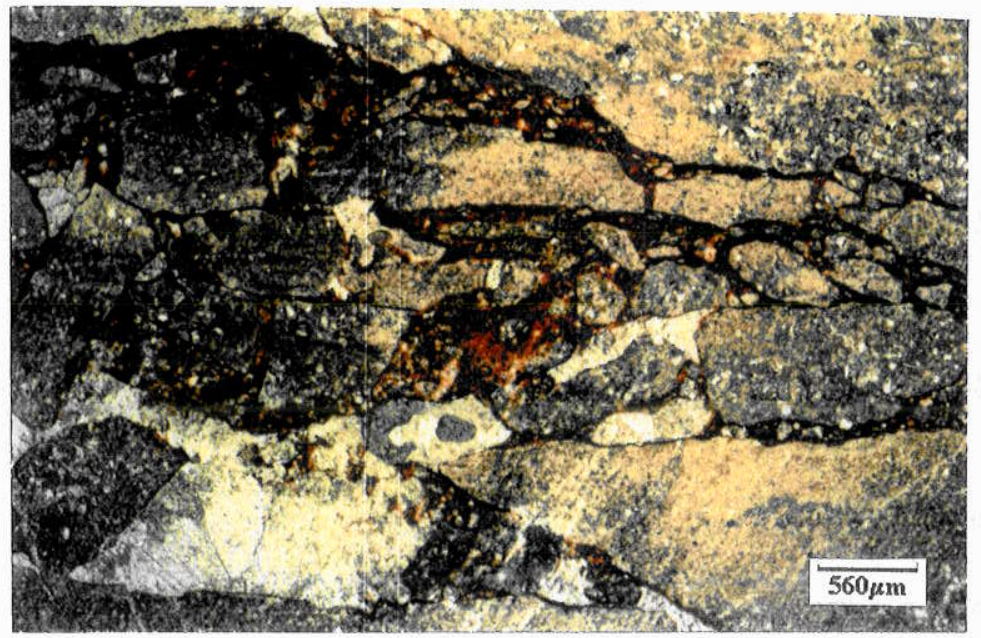

24

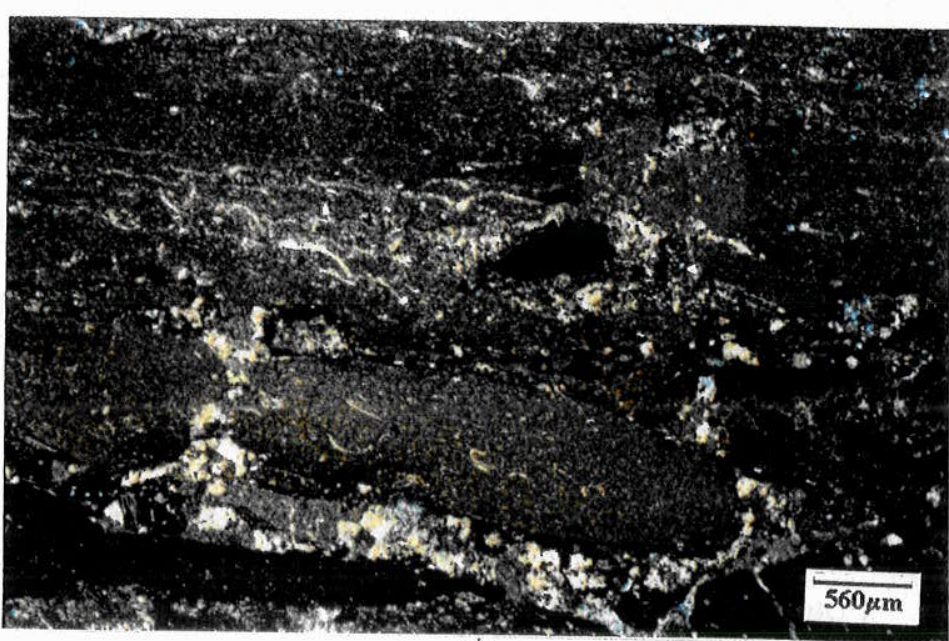

25

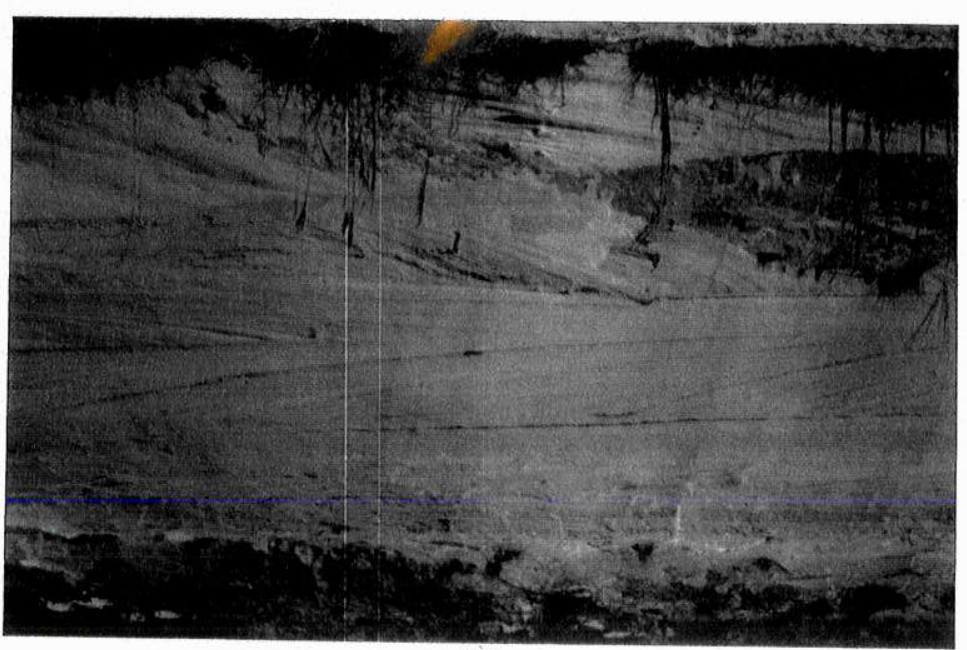

26

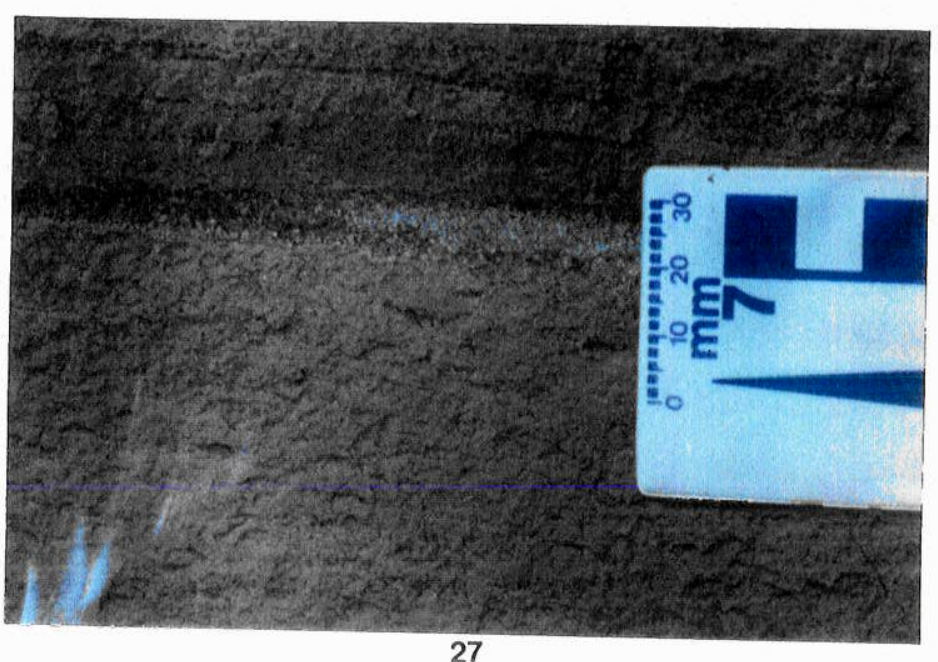

27 
PRANCHA 7 Fotomicrografias obtida por microscopia eletrônica de varredura.

Esmectita detrítica na forma de palhetas com bordas neoformadas (fotos 28 a 31).

Foto 28: $\quad$ Amostra de camada de pelito da Formação Teresina, próximo ao contato com as brechas do contato.

Foto 29: $\quad$ Amostra de pelito da Formação Corumbataí.

Foto 30: $\quad$ Amostra de camada de intraclastos das brechas do contato.

Foto 31: $\quad$ Amostra de camada interbrechas das brechas do contato.

Foto 32: Clorita na forma de plaquetas. Amostra de arenito da Formação Pirambóia.

Foto 33: $\quad$ Esmectita na forma de plaquetas com neoformação de halloysita (tubos) nas bordas. Amostra de arenito da Formação Pirambóia 


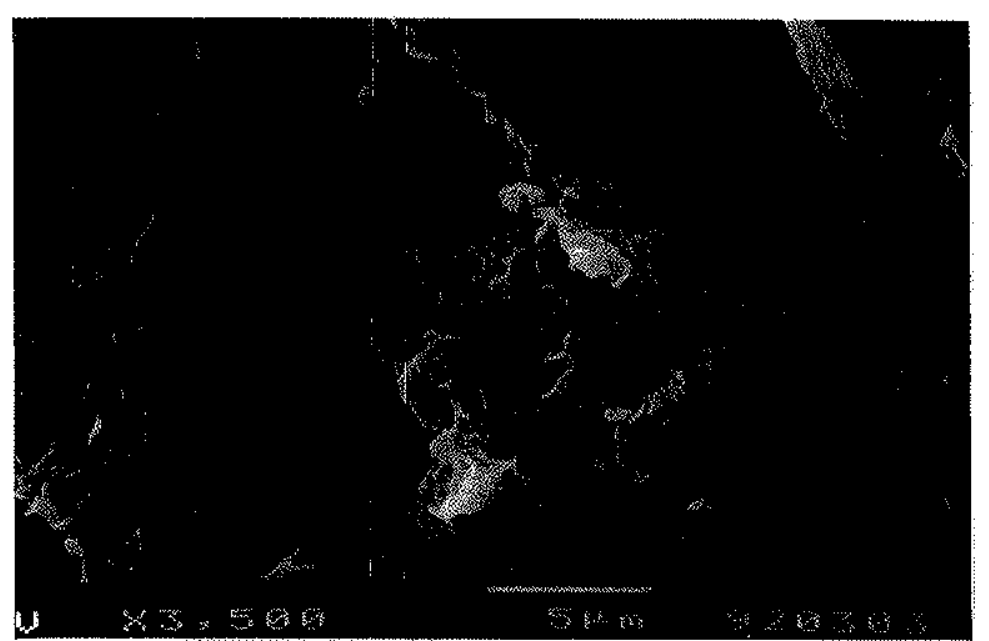

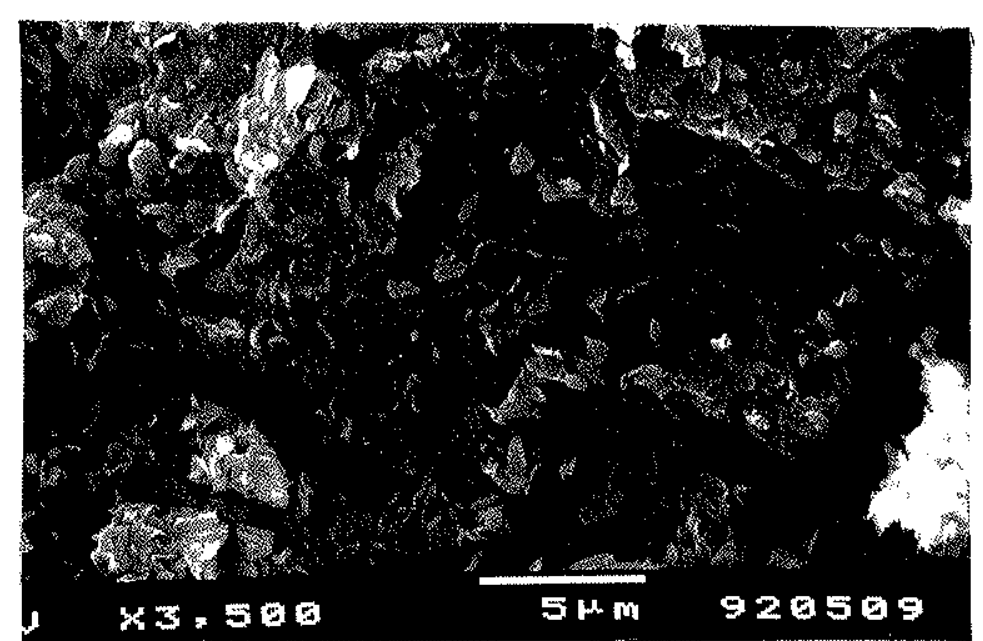

29

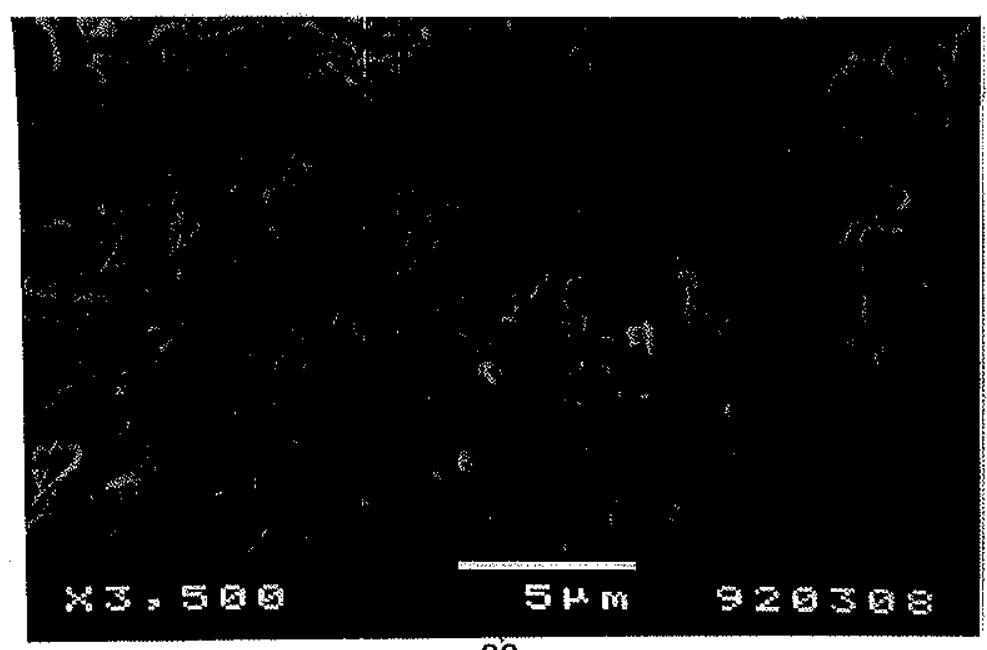

30

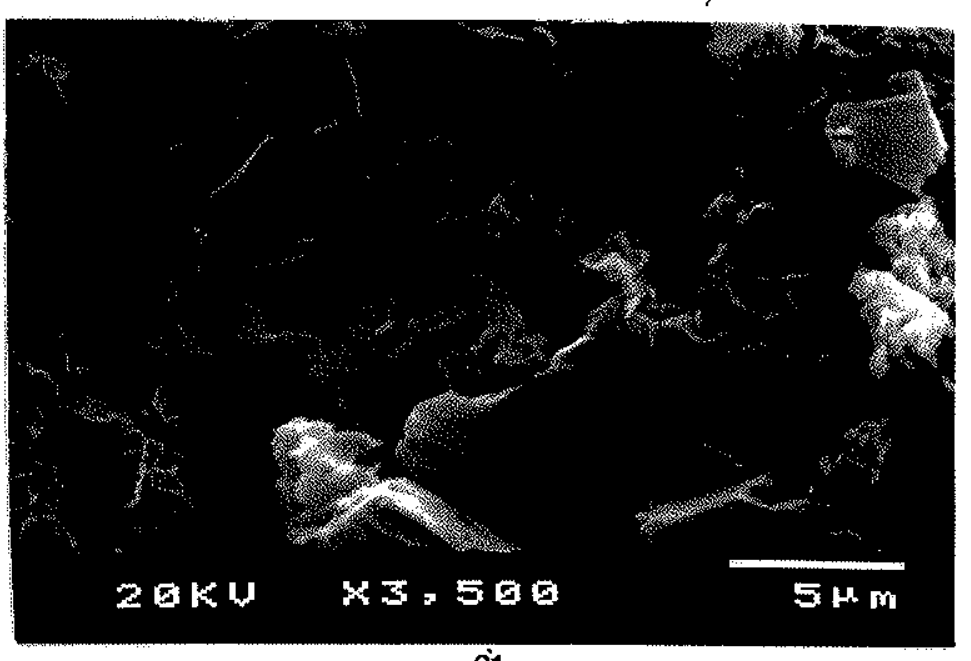

31
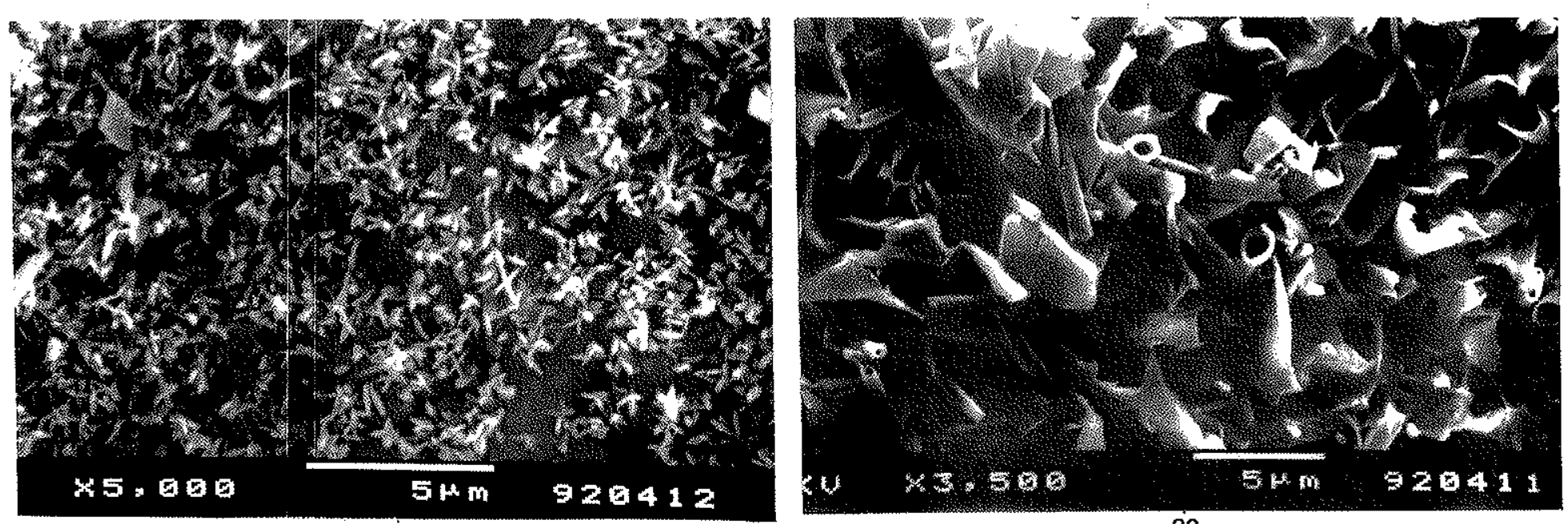
PRANCHA 8

Foto 34: $\quad$ Vista da distribuição dos corpos silicosos de Anhembi.

Foto 35: Vista das construções silicosas ligadas à atividade de gêiseres. Bacia geiserítica Monument - Yellowstone Park (Bauer 1947). 

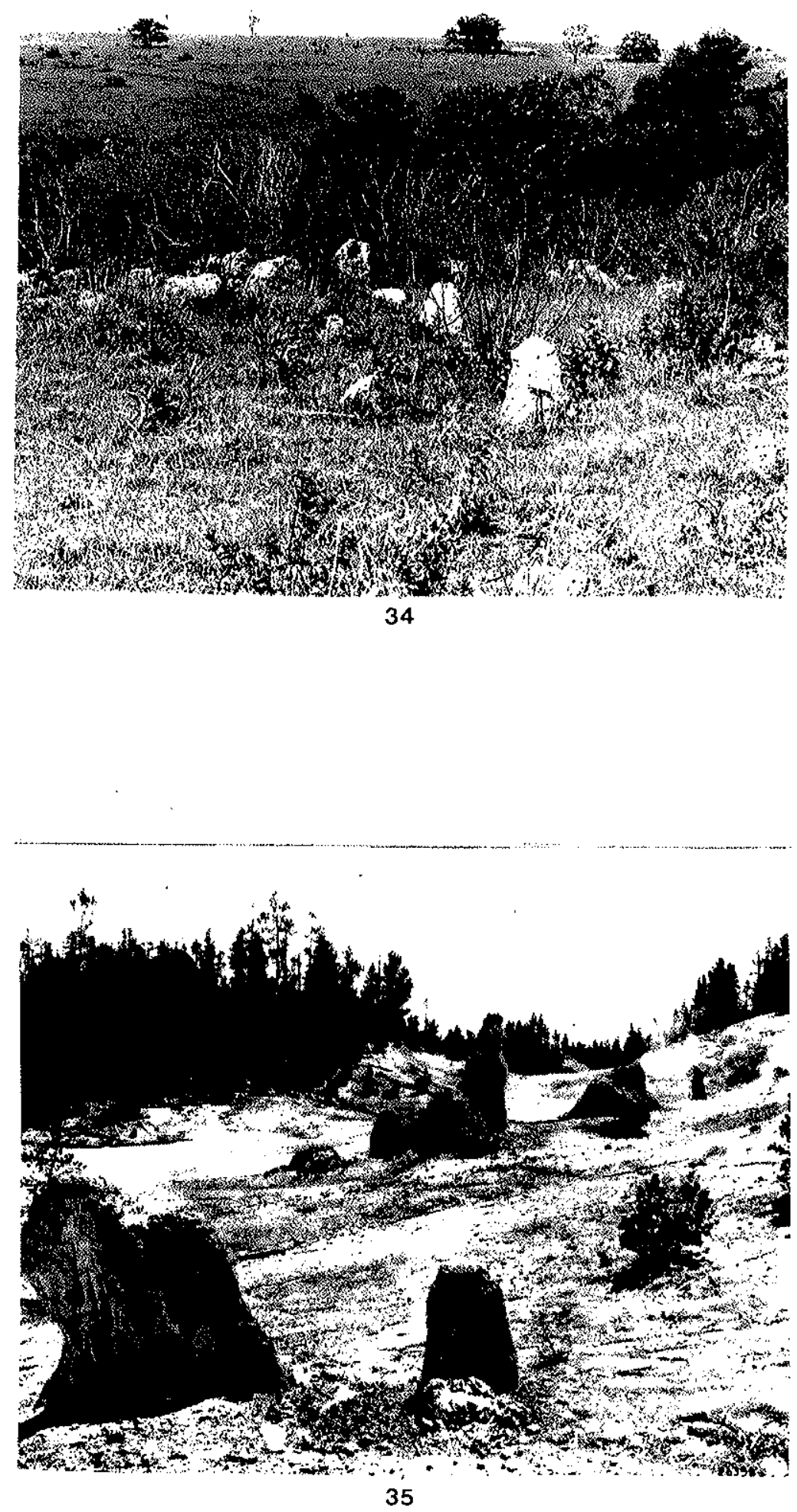
PRANCHA 9 Exemplos de contato entre o Grupo Passa Dois e a Formação Pirambóia

Formação Corumbataí-Formação Pirambóia. Estrada de ferro Rio Claro-Camaquã a $300 \mathrm{~m}$ do viaduto da rodovia SP 191, trecho Batovi-Charqueada.

Foto 36: $\quad$ Lado direito, sentido Rio Claro

Foto 37: $\quad$ Lado esquedo, sentido Rio Claro

Formação Teresina, brechas do contato, Formação Pirambóia. Rodovia Castelo Branco (SP 280), km 167

Foto 38: $\quad$ Pista capital-interior.

Foto 39: $\quad$ Pista interior-capital. 


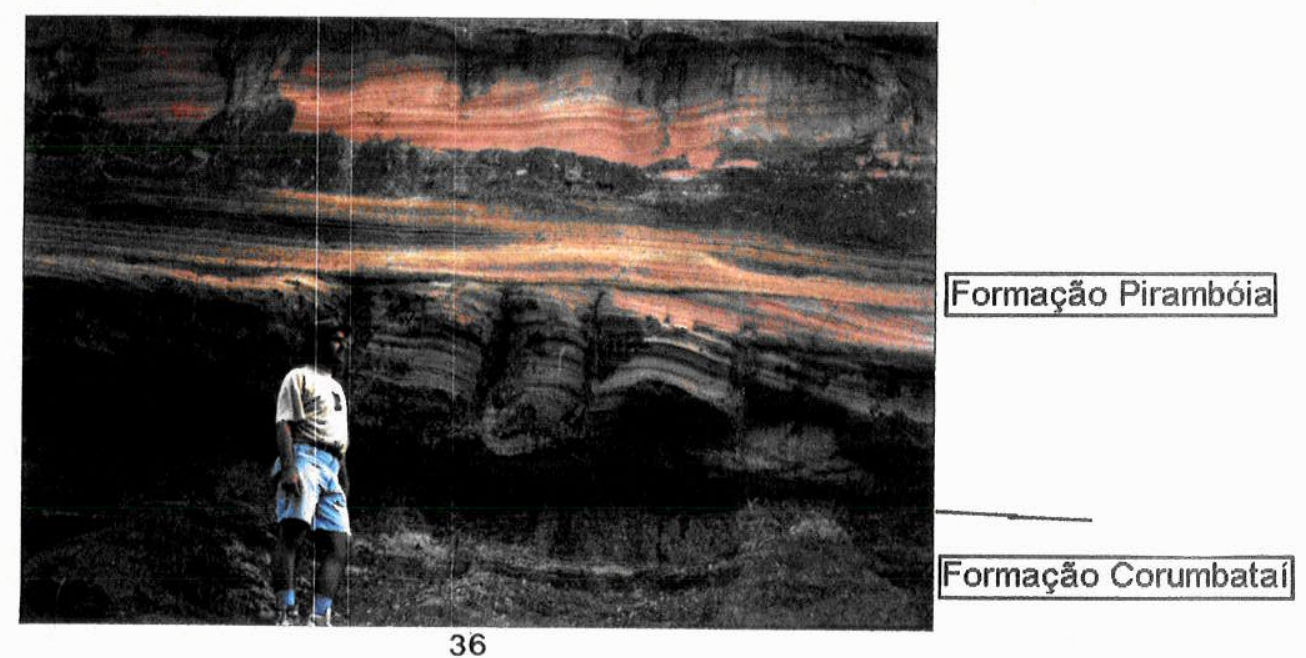

36
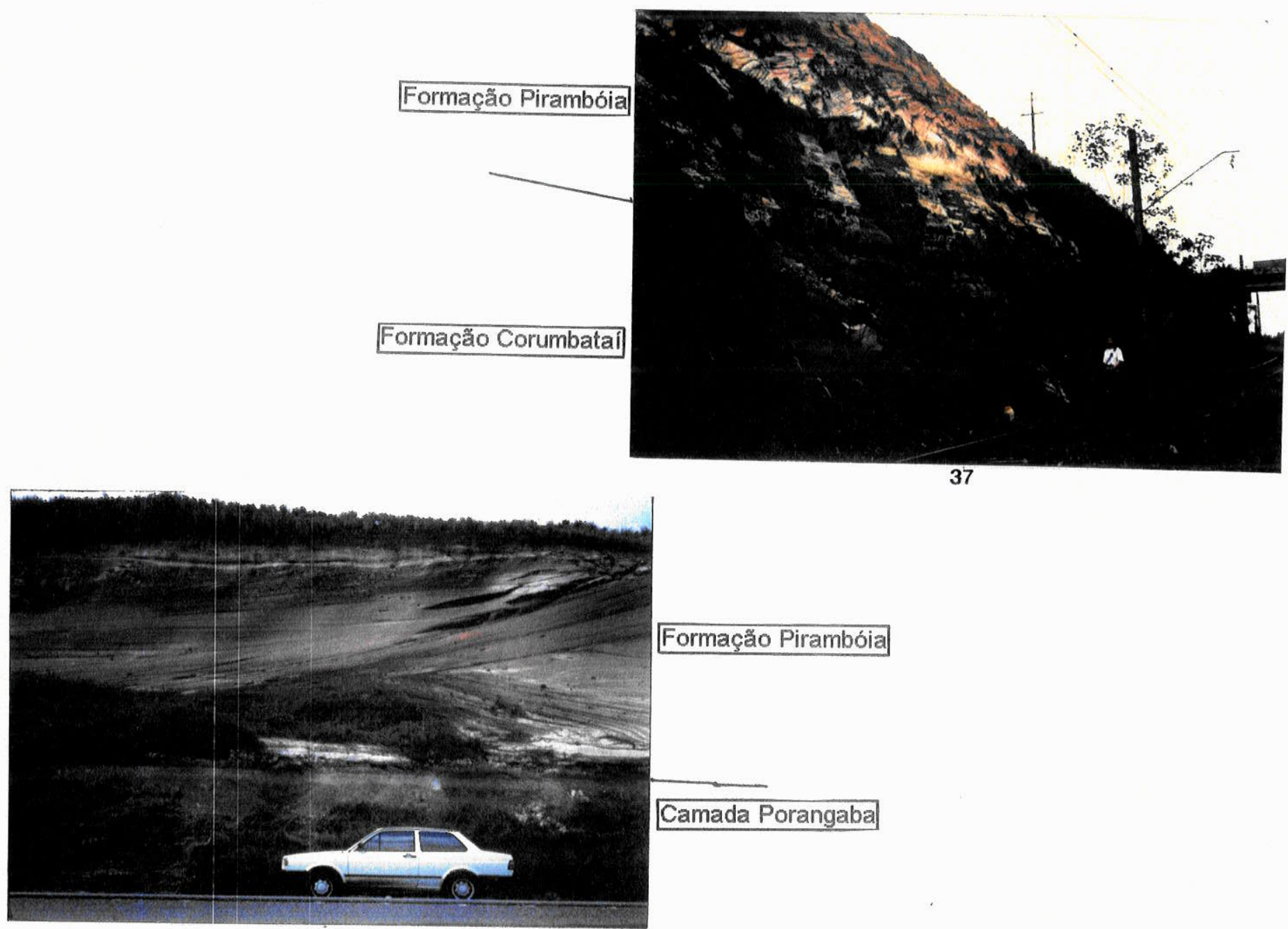

Formação Pirambóia

38

Camada Porangaba

Formação Pirambóia

Camada Porangaba

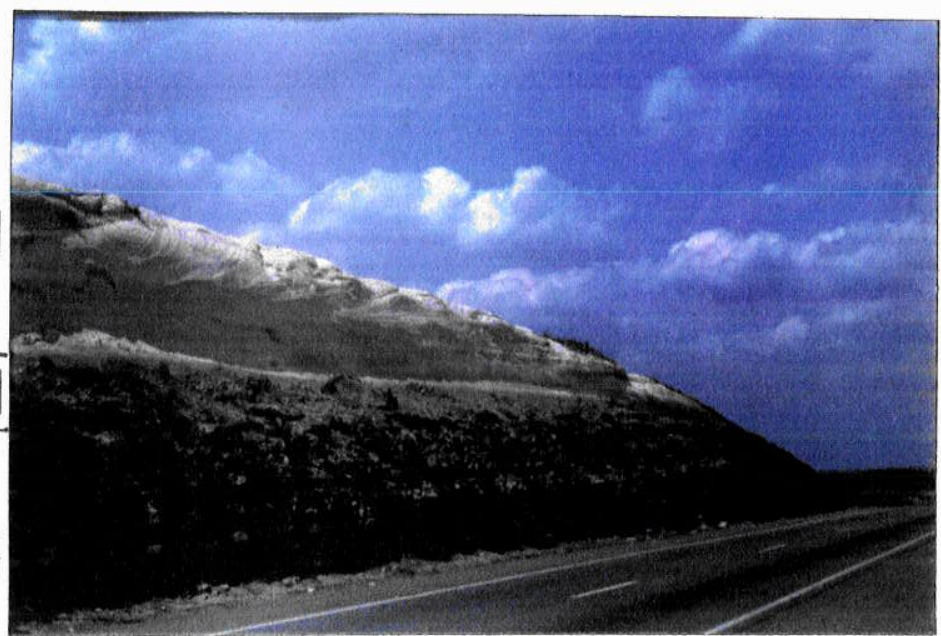


Pontos analisados - localização e unidades presentes

\begin{tabular}{|c|c|c|}
\hline PONTO & LOCALIZAÇÁO & PACOTES ROCHOSOS \\
\hline 1 & Rod. Raposo Tavares, SP 270, km 199,5 & $\begin{array}{l}\text { Formação Pirambóia; Camada } \\
\text { Porangaba (brechas do contato); } \\
\text { Formação Teresina }\end{array}$ \\
\hline 2 & $\begin{array}{l}\text { A nordeste da Cidade de Angatuba, a } 150 \mathrm{~m} \text { da } \\
\text { Capela da Faxenda Santo Antônio }\end{array}$ & $\begin{array}{l}\text { Formação Pirambóia; Camada } \\
\text { Porangaba (brechas do contato); } \\
\text { Formação Teresina }\end{array}$ \\
\hline 3 & A nordeste da Cidade de Angatuba & Formação Pirambóia \\
\hline 4 & $\begin{array}{l}\text { Aproximadamente } 2 \mathrm{~km} \text { a leste da Cidade de } \\
\text { Angatuba }\end{array}$ & $\begin{array}{l}\text { Formação Pirambóia; Camada } \\
\text { Porangaba (brechas do contato); } \\
\text { Formação Teresina }\end{array}$ \\
\hline 5 & Rod. Raposo Tavares, SP $270, \mathrm{~km} 182$ & Formação Teresina \\
\hline 6 & $\begin{array}{l}\text { Acesso ivens Vieira, SP } 268 \text {, a } 5 \mathrm{~km} \text { de } \\
\text { Angatuba }\end{array}$ & $\begin{array}{l}\text { Formação Pirambóia; Camada } \\
\text { Porangaba (brechas do contato); } \\
\text { Formação Teresina }\end{array}$ \\
\hline 7 & Rod. Castelo Branco, SP 280, km 165 & Formação Teresina \\
\hline 8 & $\begin{array}{l}\text { Município de Corumbataí, a } 5 \mathrm{~km} \text { do trevo de } \\
\text { acesso pepla Rod. Washington Luís }\end{array}$ & Formação Pirambóia \\
\hline 9 & $\begin{array}{l}\text { Município de Corumbataí, a } 6 \mathrm{~km} \text { do trevo de } \\
\text { acesso pepla Rod. Washington Luís }\end{array}$ & Formação Pirambóia \\
\hline 10 & $\begin{array}{l}\text { Município de Corumbataí, a } 7,5 \mathrm{~km} \text { do trevo de } \\
\text { acesso pepla Rod. Washington Luís }\end{array}$ & $\begin{array}{l}\text { Formação Pirambóia; Camada } \\
\text { Porangaba (brechas do contato); } \\
\text { Formação Corumbataí }\end{array}$ \\
\hline 11 & A sudeste do Município de Corumbatai & $\begin{array}{l}\text { Formação Pirambóia; Camada } \\
\text { Porangaba (brechas do contato); } \\
\text { Formação Corumbataí }\end{array}$ \\
\hline 12 & Rod. Washington Luís, SP $310, \mathrm{~km} 193$ & Formação Botucatú \\
\hline 13 & Rod. Washington Luís, SP $310, \mathrm{~km} 188,5$ & $\begin{array}{l}\text { Formação Pirambóia; Camada } \\
\text { Porangaba (brechas do contato); } \\
\text { Formação Corumbataí }\end{array}$ \\
\hline 14 & $\begin{array}{l}\text { Estrada de Ferro Rio Claro-Itirapina, a } 200 \mathrm{~m} \text { do } \\
\text { viaduto da SP } 191 \text { - Rio Claro-Charqueada. }\end{array}$ & $\begin{array}{l}\text { Formação Pirambóia; Formação } \\
\text { Corumbataí }\end{array}$ \\
\hline 15 & $\begin{array}{l}\text { Rod. Castelo Branco, SP } 280, \mathrm{~km} \mathrm{166,5} \\
\text { (sentido capital-interior) }\end{array}$ & $\begin{array}{l}\text { Formação Pirambóia; Camada } \\
\text { Porangaba (brechas do contato); } \\
\text { Formação Teresina }\end{array}$ \\
\hline 16 & $\begin{array}{l}\text { Rod. Castelo Branco, SP 280, km 166,5 } \\
\text { (sentido interior capital) }\end{array}$ & $\begin{array}{l}\text { Formação Pirambóia; Camada } \\
\text { Porangaba (brechas do contato); } \\
\text { Formação Teresina }\end{array}$ \\
\hline 17 & $\begin{array}{l}\text { Rod. Castelo Branco, SP 280, km } 175 \text { (sentido } \\
\text { capital-interior) }\end{array}$ & $\begin{array}{l}\text { Formação Pirambóia; Formação } \\
\text { Teresina (contato por falha) }\end{array}$ \\
\hline 18 & $\begin{array}{l}\text { Rod. Castelo Branco, SP 280, km } 168 \text { (sentido } \\
\text { interior-capital) }\end{array}$ & Formação Teresina \\
\hline 19 & SP 304, Piracicaba-São Pedro, km 184,5 & Formação Pirambóia \\
\hline 20 & SP 304, Piracicaba-São Pedro, km 183 & $\begin{array}{l}\text { Formação Pirambóia; Camada } \\
\text { Porangaba (brechas do contato); } \\
\text { Formação Corumbataí }\end{array}$ \\
\hline 21 & SP 304, Piracicaba-São Pedro, km 182 & Formação Corumbataí \\
\hline 22 & $\begin{array}{l}\text { Rod. Mal. Rondom, SP } 300 \text {, próximo da Cidade } \\
\text { de Conchas }\end{array}$ & Formaçāo Teresina \\
\hline 23 & $\begin{array}{l}\text { Rod. Mal. Rondom, SP } 300 \text {, a } 6 \mathrm{~km} \text { da Cidade } \\
\text { de Conchas }\end{array}$ & $\begin{array}{l}\text { Formação Pirambóia; Camada } \\
\text { Porangaba (brechas do contato); } \\
\text { Formação Teresina }\end{array}$ \\
\hline 24 & $\begin{array}{l}\text { Rod. Mal. Rondom, SP } 300 \text {, a } 8 \mathrm{~km} \text { da Cidade } \\
\text { de Conchas }\end{array}$ & Formação Teresina \\
\hline 25 & $\begin{array}{l}\text { Estrada Pirambóia-Piracicaba, Próximo a } \\
\text { Cidade de Anhembi. }\end{array}$ & Formação Teresina \\
\hline 26 & $\begin{array}{l}\text { Rod. Mal. Rondom, SP } 300 \text {, a } 40 \mathrm{~km} \text { da Cidade } \\
\text { de Conchas }\end{array}$ & Formação Pirambóia \\
\hline 27 & A leste da Cidade de Santa Ros de Viterbo & Formação Corumbataí \\
\hline
\end{tabular}




\begin{tabular}{|c|c|c|}
\hline 28 & $\begin{array}{l}\text { Rod. São Carlos-Porto Ferreira, próximo do } \\
\text { acesso para Descalvado }\end{array}$ & Formação Pirambóia \\
\hline 29 & $\begin{array}{l}\text { Rod. Anhanguera, SP } 330 \text {, a } 10 \mathrm{~km} \text { do acesso } \\
\text { para Porto Ferreira }\end{array}$ & Formação Pirambóia \\
\hline 30 & $\begin{array}{l}\text { Estrada Anhembi-Piracicaba, a } 30 \mathrm{~km} \text { de } \\
\text { Anhembi }\end{array}$ & Formação Pirambóia \\
\hline 31 & $\begin{array}{l}\text { Estrada Anhembi-Piracicaba, a } 31 \mathrm{~km} \text { de } \\
\text { Anhembi }\end{array}$ & Formação Pirambóia \\
\hline 32 & Estrada Conchas-Piracicaba, a 11 km de Jibóia & Formação Pirambóia \\
\hline 33 & Estrada Conchas-Piracicaba, a $10 \mathrm{~km}$ de Jibóia & Formação Corumbataí \\
\hline 34 & Estrada Conchas-Piracicaba, a 15 km de Jibóia & $\begin{array}{l}\text { Formação Pirambóia; Formação } \\
\text { Corumbatai (não foi observado } \\
\text { diretamente o contato) }\end{array}$ \\
\hline 35 & Estrada Porangaba-Bofete, km 174 & $\begin{array}{l}\text { Formação Pirambóia; Camada } \\
\text { Porangaba (brechas do contato); } \\
\text { Formação Teresina }\end{array}$ \\
\hline 36 & $\begin{array}{l}\text { Rod. do Açucar, SP 308, km 186, próximo a } \\
\text { Santa Luzía }\end{array}$ & Formação Corumbataí \\
\hline 37 & $\begin{array}{l}\text { Estrada Charqueada-São Pedro, a } 500 \text { m da } \\
\text { entrada de Charqueada }\end{array}$ & $\begin{array}{l}\text { Formação Corumbataí; Formação } \\
\text { Pirambóia }\end{array}$ \\
\hline 38 & $\begin{array}{l}\text { Estarda Charqueada- São Pedro, a } 12 \text { km de } \\
\text { São Paulo }\end{array}$ & Formação Pirambóia \\
\hline 39 & $\begin{array}{l}\text { A } 1 \mathrm{~km} \text { do trevo de acesso a Fartura pela SP } \\
287 \text {, estrada Fartura-Piraju }\end{array}$ & Formação Teresina \\
\hline 40 & $\begin{array}{l}\text { A } 6 \mathrm{~km} \text { do trevo de acesso a Fartura pela SP } \\
287 \text {, estrada Fartura-Piraju }\end{array}$ & $\begin{array}{l}\text { Formação Teresina; Formação } \\
\text { Pirambóia; Formação Rio do } \\
\text { Rasto }\end{array}$ \\
\hline 41 & $\begin{array}{l}\text { A } 8 \mathrm{~km} \text { do trevo de acesso a Fartura pela SP } \\
287 \text {, estrada Fartura-Piraju }\end{array}$ & Formação Pirambóia \\
\hline 42 & $\begin{array}{l}\text { Estrada antiga Fartura-Piraju, a } \\
\text { aproximadamente } 5 \mathrm{~km} \text { de Fartura }\end{array}$ & Formação Pirambóia \\
\hline 43 & $\begin{array}{l}\text { A } 10 \mathrm{~km} \text { do trevo de acesso a Fartura pela SP } \\
287 \text {, estrada Fartura-Piraju }\end{array}$ & Foramação Botucatú \\
\hline 44 & Estrada Itaí-Taquarituba, a $5 \mathrm{~km}$ de Taquarituba & $\begin{array}{l}\text { Formação Pirambóia; Camada } \\
\text { Porangaba (brechas do contato); } \\
\text { Formação Teresina }\end{array}$ \\
\hline 45 & $\begin{array}{l}\text { Rod. Castelo Branco, SP 280, km 173, } 5 \\
\text { (sentido interio-capital) }\end{array}$ & Formação Pirambóia \\
\hline 46 & $\begin{array}{l}\text { Rod. Irineu Penteado, SP 191, a } 10 \mathrm{~km} \text { de } \\
\text { Charqueada }\end{array}$ & Formação Pirambóia \\
\hline 47 & Estrada Taguaí-Tejupá & Formação Pirambóia \\
\hline 48 & A sul da Cidade de Itirapina & $\begin{array}{l}\text { Formação Pirambóia; Formação } \\
\text { Corumbataí }\end{array}$ \\
\hline 49 & $\begin{array}{l}\text { PR 218, estarda Carlópolis-Joaquim Távora, a } \\
10 \text { km de Carlópolis, PR }\end{array}$ & $\begin{array}{l}\text { Membro Serinha da Formação } \\
\text { Rio do Rasto }\end{array}$ \\
\hline 50 & $\begin{array}{l}\text { PR 218, estarda Carlópolis-Joaquim Távora, a } \\
13 \text { km de Carlópolis, PR }\end{array}$ & $\begin{array}{l}\text { Membro Serinha da Formação } \\
\text { Rio do Rasto }\end{array}$ \\
\hline 51 & PR 092, Rod. Joaquim Távora-Cambará, PR & $\begin{array}{l}\text { Membro Serinha da Formação } \\
\text { Rio do Rasto }\end{array}$ \\
\hline 52 & $\begin{array}{l}\text { PR 092, Rod. Joaquim Távora-Cambará, no } \\
\text { trevo para Guapirama, PR }\end{array}$ & Formação Botucatu \\
\hline 53 & $\begin{array}{l}\text { PR 092, Rod. Joaquim Távora-Cambará, no } \\
\text { trevo da BR 153, PR }\end{array}$ & $\begin{array}{l}\text { Membro Serrinha (Formação Rio } \\
\text { do Rasto); Formação Pirambóia }\end{array}$ \\
\hline 54 & $\begin{array}{l}5 \mathrm{~km} \text { a oeste da Cidade de Paranapanema, } \\
\text { loteamento novo, próximo a conjunto de casas } \\
\text { populares }\end{array}$ & Formação Pirambóia \\
\hline 55 & Próximo do Município de Tejupá & $\begin{array}{l}\text { Formação Pirambóia; Camada } \\
\text { Porangaba (brechas do contato); } \\
\text { Formação Rio do Rasto }\end{array}$ \\
\hline 56 & Próximo a Cidade de Fartura & Formação Rio do Rasto \\
\hline 57 & $\begin{array}{l}\text { Rod. Raposo Tavares, SP } 270, \mathrm{~km} 199,5 \text { (corte } \\
\text { novo) }\end{array}$ & $\begin{array}{l}\text { Formação Pirambóia; Camada } \\
\text { Porangaba (brechas do contato); } \\
\text { Formação Teresina }\end{array}$ \\
\hline
\end{tabular}




\begin{tabular}{|c|l|l|}
\hline 58 & $\begin{array}{l}\text { A 8km da cidade de Anhembi, em frente à sede } \\
\text { do sítio do senhor Joaquim }\end{array}$ & $\begin{array}{l}\text { Formação Pirambóia; Camada } \\
\text { Porangaba (brechas do contato); } \\
\text { Formação Teresina }\end{array}$ \\
\hline 59 & $\begin{array}{l}\text { Subestação de Energia Elétrica da Parada } \\
\text { Camaquã, na antiga Ferrovia Rio Claro-Itirapina } \\
\text { (desativada), a noroeste da Cidade de Batovi }\end{array}$ & $\begin{array}{l}\text { Formação Pirambóia; Camada } \\
\text { Porangaba (brechas do contato); } \\
\text { Formação Corumbataí }\end{array}$ \\
\hline 60 & $\begin{array}{l}\text { Estrada Descalvado (saindo do cimitério)- } \\
\text { Fazenda Nova América }\end{array}$ & $\begin{array}{l}\text { Formação Pirambóia; Camada } \\
\text { Porangaba (brechas do contato); } \\
\text { Formação Corumbataí }\end{array}$ \\
\hline 61 & $\begin{array}{l}\text { A 10km a osete da cidade de Anhembi, acesso } \\
\text { de terra, próximo ao vale do ribeirão do Retiro }\end{array}$ & Estruturas de sílex \\
\hline 62 & $\begin{array}{l}\text { A oeste da Cidade de Anhembi, ao lado do } \\
\text { porto de areia Areião }\end{array}$ & Formação Teresina \\
\hline 63 & $\begin{array}{l}\text { Rod. Mal. Rondom, ao lado da Cidade de } \\
\text { Conchas }\end{array}$ & Formação Teresina \\
\hline
\end{tabular}

